\title{
القرضاوي مرجعًا: الفكرة والنشأة والمكونات
}

\section{معتز الخخطيب}

\section{مقدمة: يوسف القرضاوي والمرجعية}

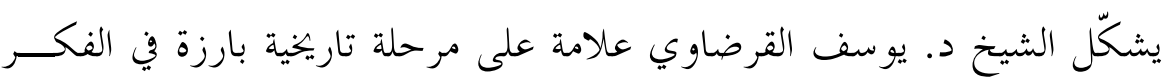

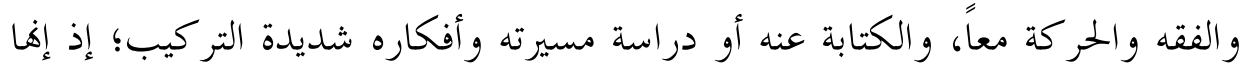

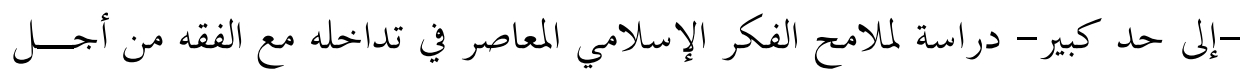

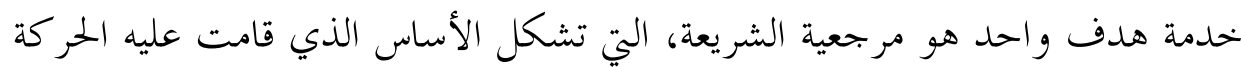

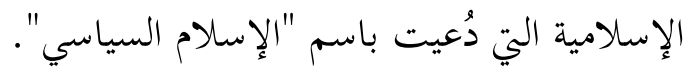

ثم إن دراسة فقه القرضاوي من شأها أن تقف على المآل الذي وصلت إليه مسيرة

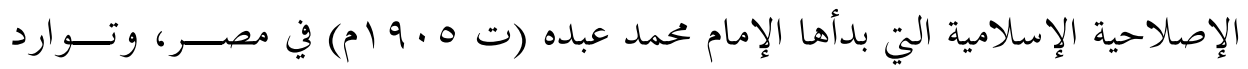

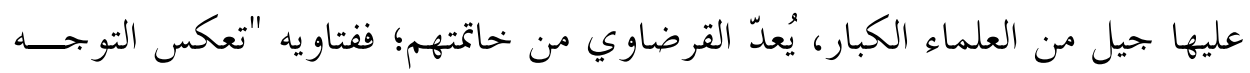

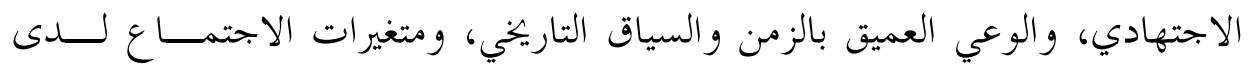

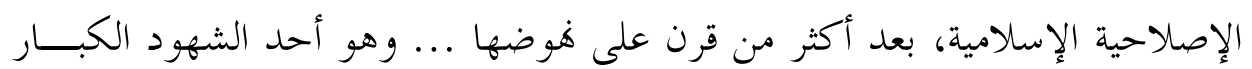

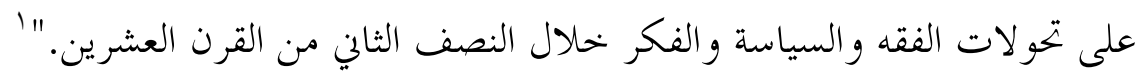
وإلى الشيخ القرضاوي -مع الشيخ محمد الغزالي رحمه الله- يرجع الأثر الكبير في

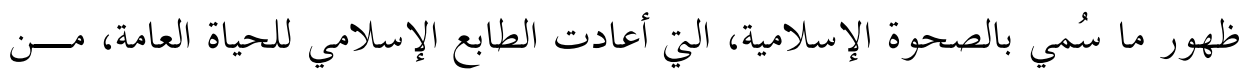
خلال تحويل ميراث الإصلاحية الإسلامية إلى ميراث شبي جماهيري، الأمر الذي أثنار

باحث سوري متخصص في قضايا الفكر الإسلامي. يعــــ أطروحسـة دكتـــوراه في علــوم الســنة النبويــة.

Alkhateeb2@hotmail.com

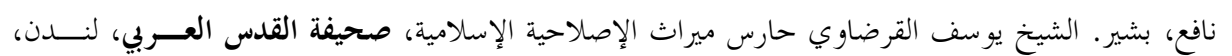

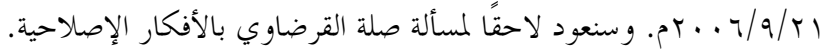




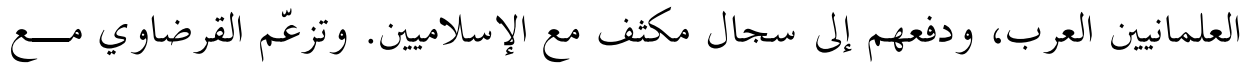

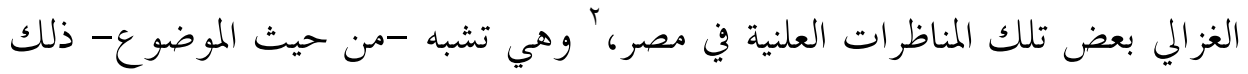

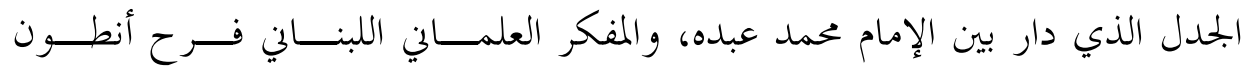

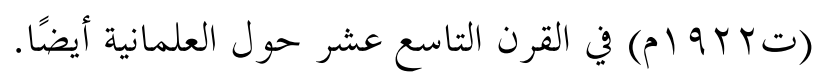

ومع تقادم الزمن وتطورات الحياة، تعاظم دورٌ القرضاوي، حتى أصبح يمثل -إلى

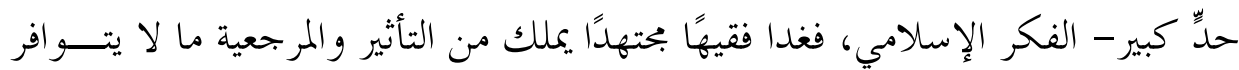

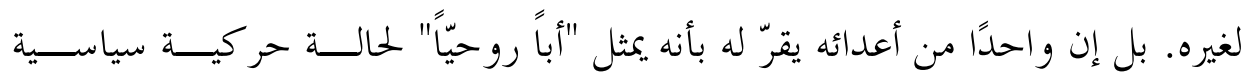

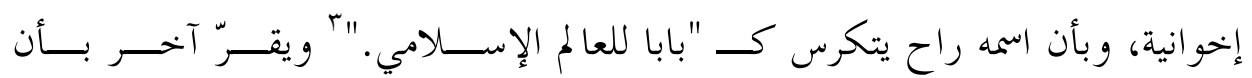
القرضاوي وآخرين - كالمودودي وقطب- "استطاعوا إشغال الفكر العربي الليــبرالي

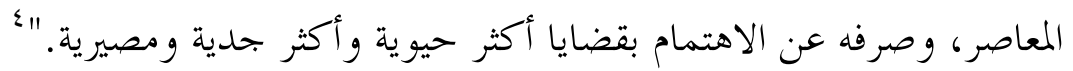

و السؤ ال عن المرجعية المرتبطة بشخص، سؤ ال غريب عن العالم السُّبِّ، فـــالفكر

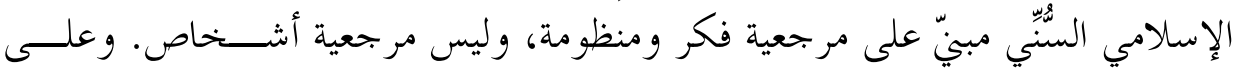

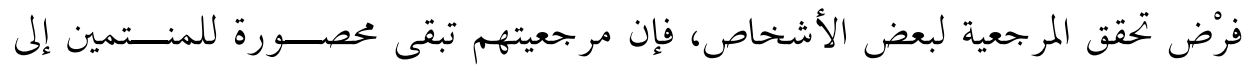

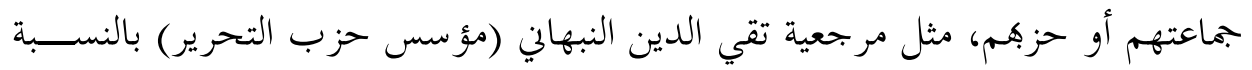

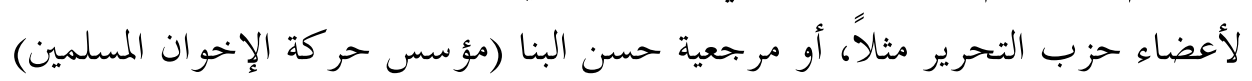

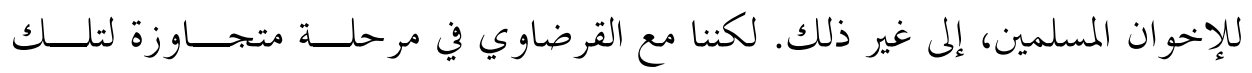

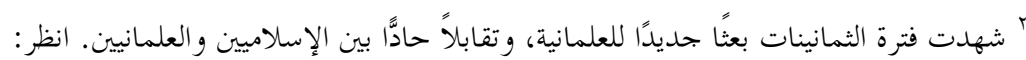

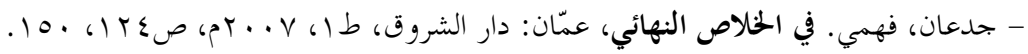

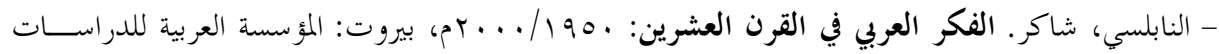

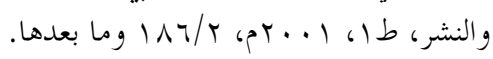

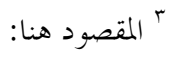

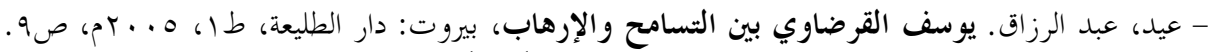

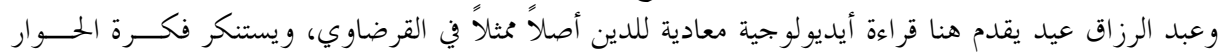

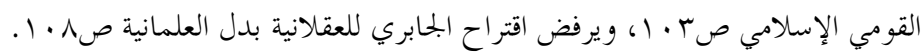

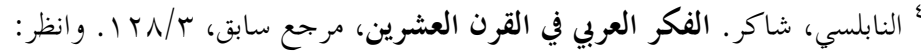

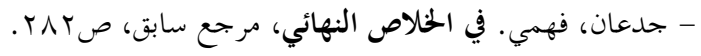


المرجعيات الجزئية أو الحزبية، ومرجعية القرضاوي ثابتة لدرجة أن شخصًا مثل حسن

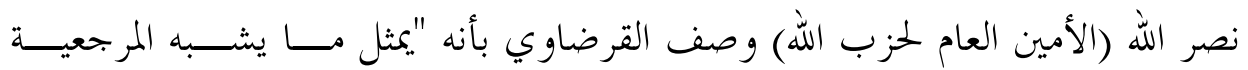

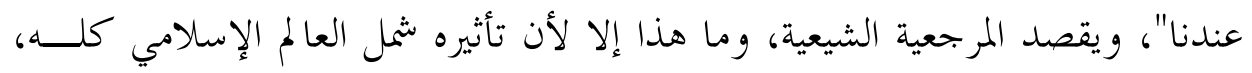

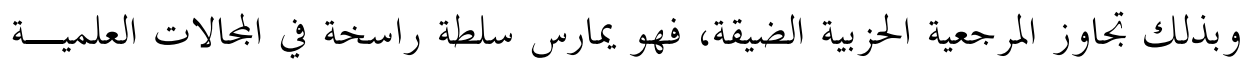

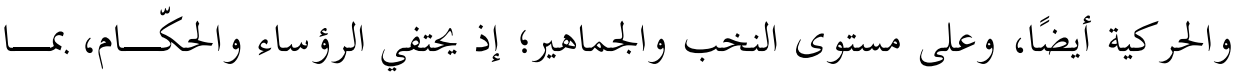

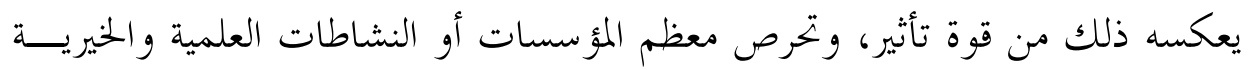

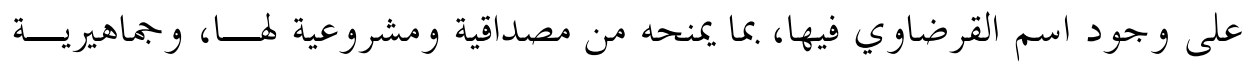
عريضة. ولعل مما له دلالة هنا: حضوره وتأثيره في ثلاث قضايا كبرى وقعت مؤخرًا: أزمة

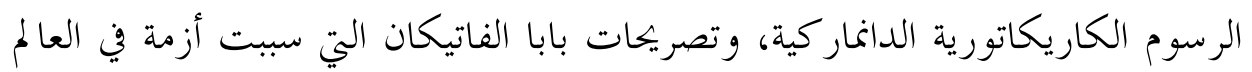

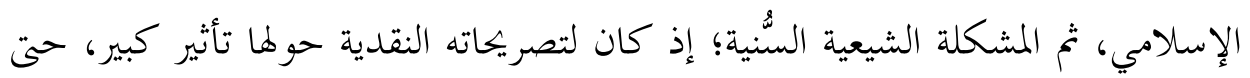

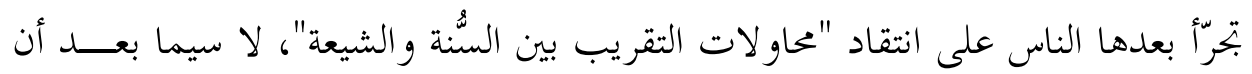
تسلَّم الشيعة السلطة في العراق.

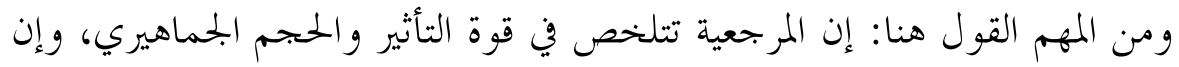

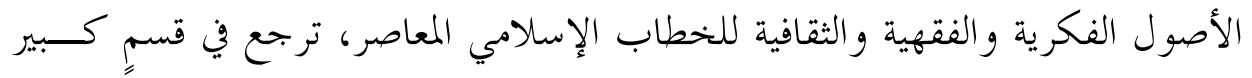

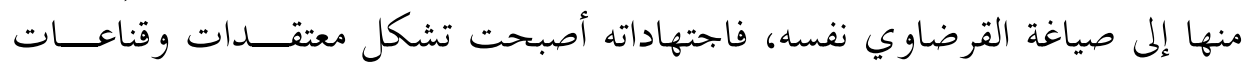
جمهور عريض من المؤمنين، وتصدر عنها المشروعية الدينية السائدة.

وبناء على ما سبق، نرى أن مرجعية القرضاوي ليست من نمط المرجعية الشيعية،

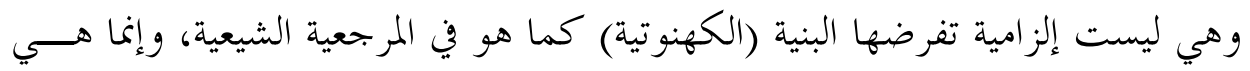

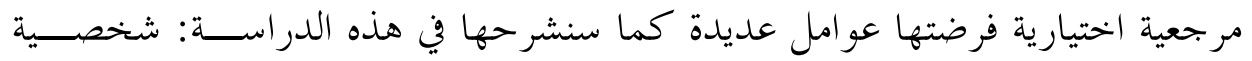

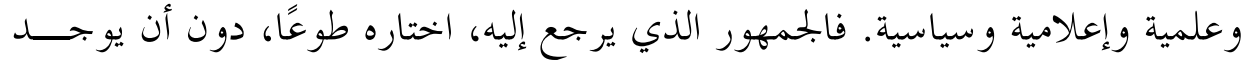

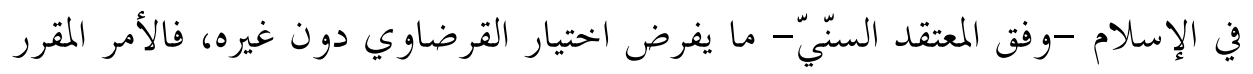

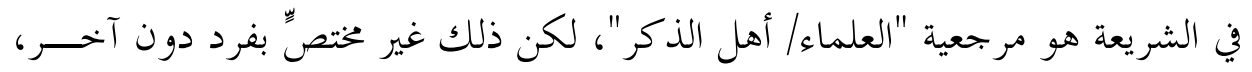


ثم إن هؤلاء العلماء ينتمون إلى منظومة فكرية متحدة الأصول والقواعد، ومتواصلة مع الع القعاء تراث العلماء السابقين عبر القرون.

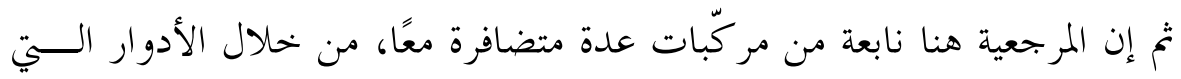

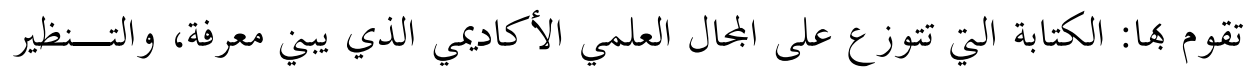

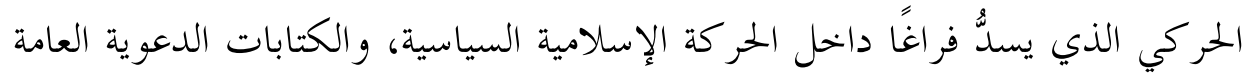

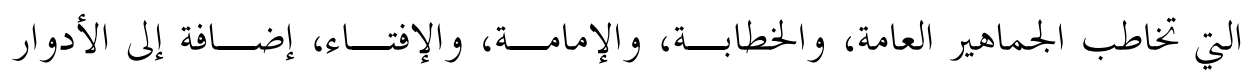

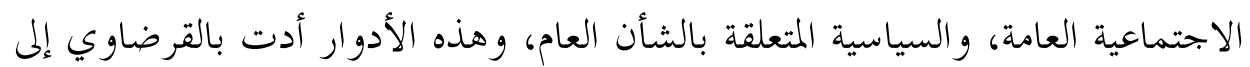

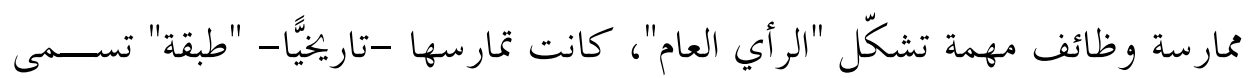

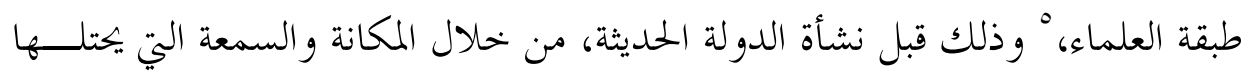

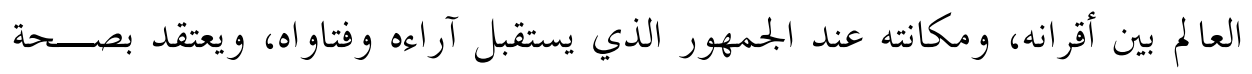

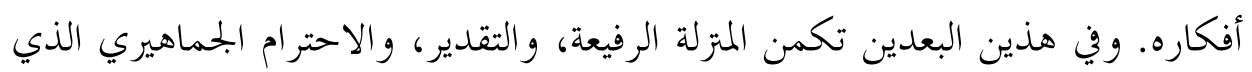

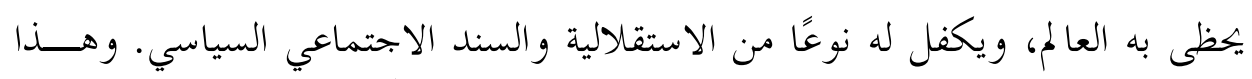

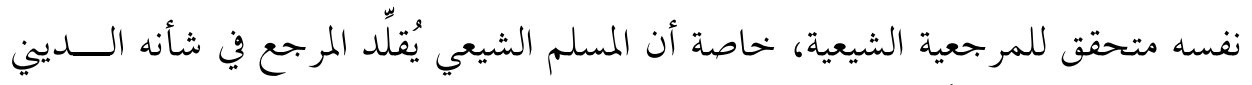

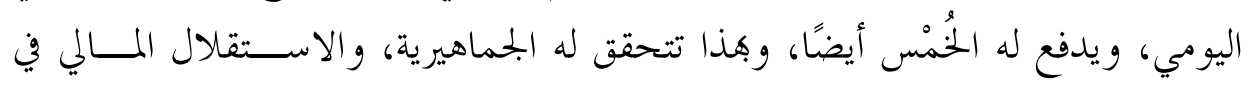

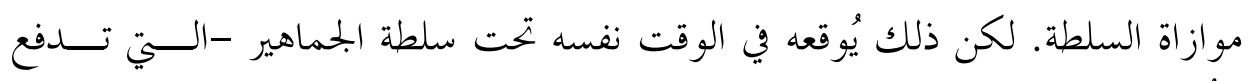

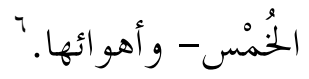

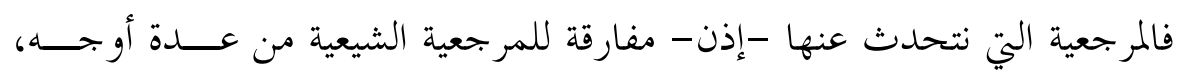

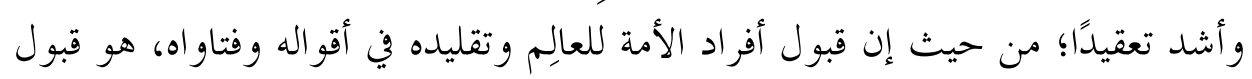

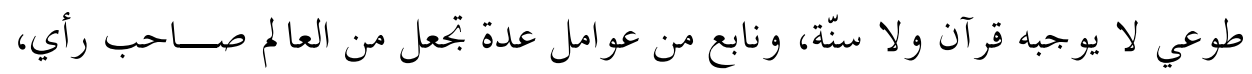

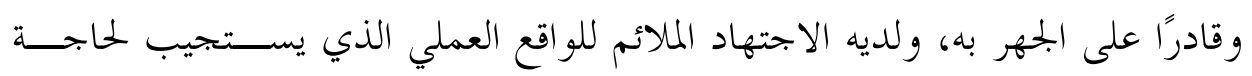

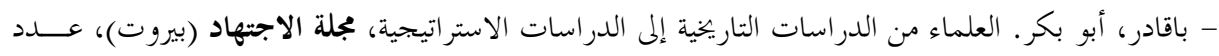

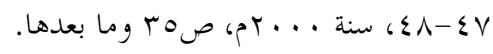

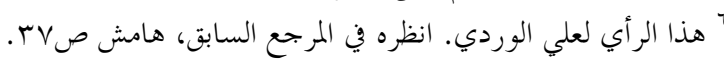




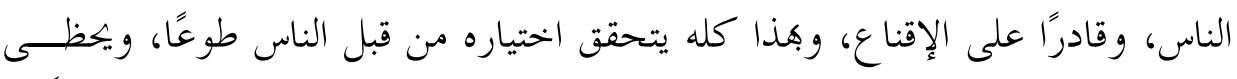

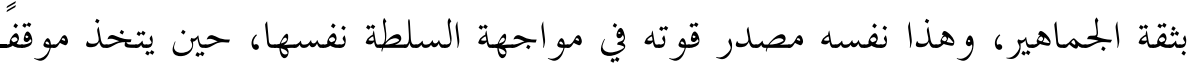
معارضًا لسياستها.

تم إن المرجعية الشيعية تنقسم إلى نوعين: مرجعية تقليد وهذه هي السائدة بــين

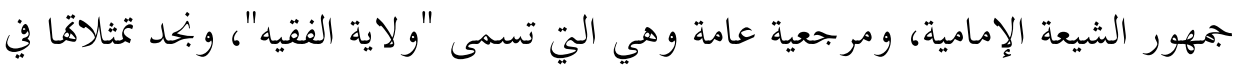

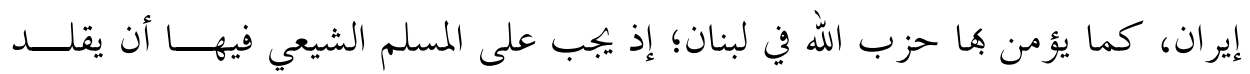

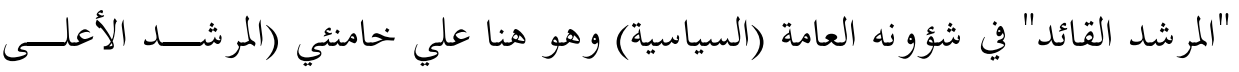

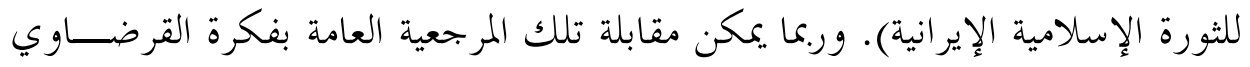

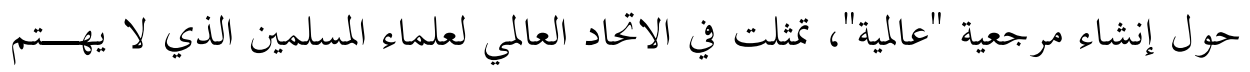

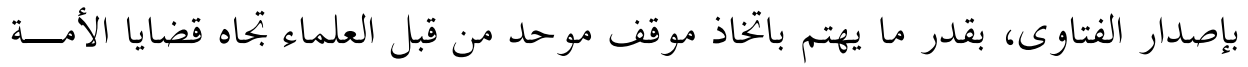

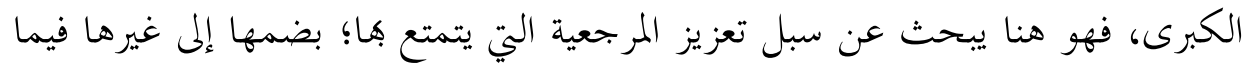

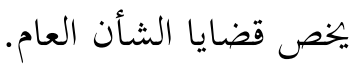

واستناداً إلى ما سبق سندرس القرضاوي، ليس بوصفه شخصًا، بل بوصفه شاهدًا

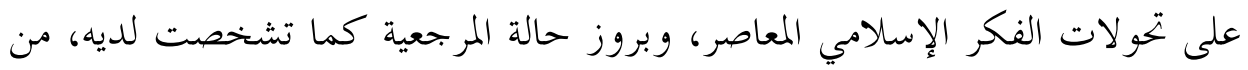

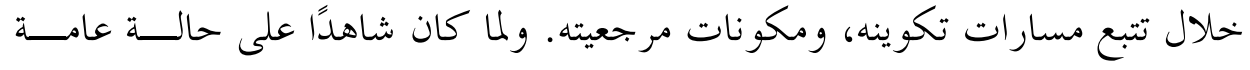

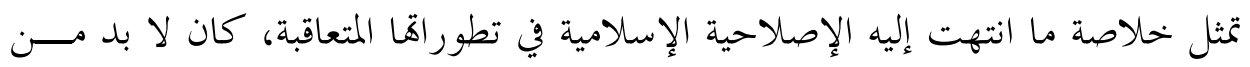

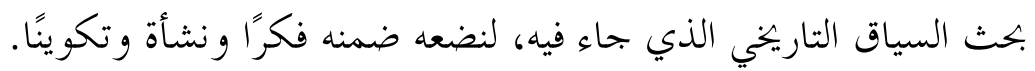

أولاً: المرجعية في سياقها التاريخي

سقطت الخلافة الإسلامية في النصف الأول من القرن العشرين، وبعد الاستقلال

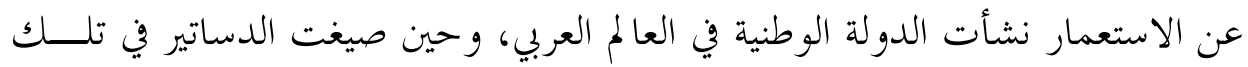

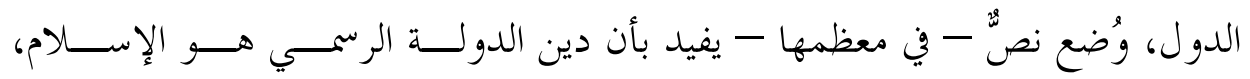

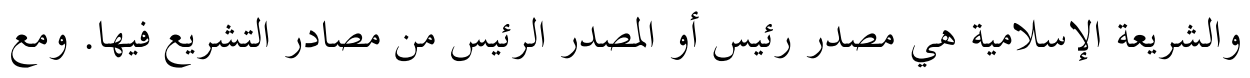

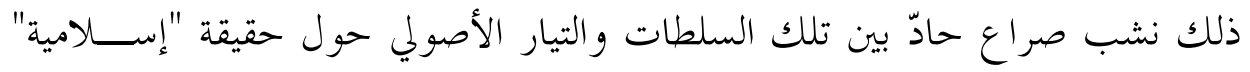


الدولة، ونشأت أطروحة "الدولة الإسلامية" التي تتلخص مهمتها في تطبيق الشــريعة،

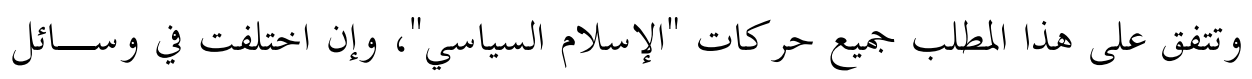

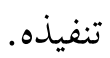

وفي ظل ذلك الصراع والجدل الذي كان يدور معه، كانت فكرة المرجعية تشغل

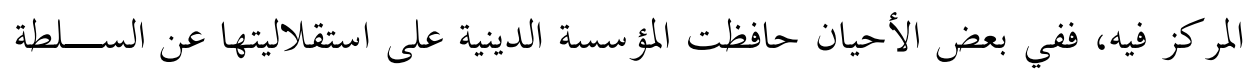

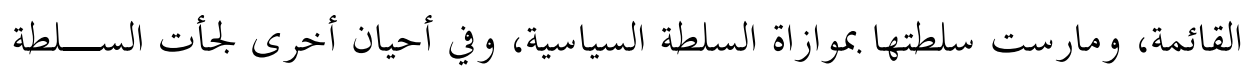

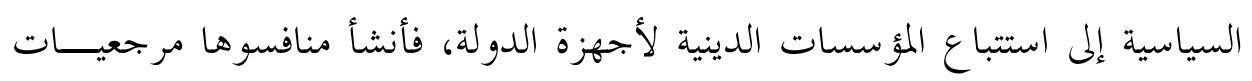
دينية موازية، كثيرًا ما اكتسبت شعبيتها من استقلالها عن الدولة.

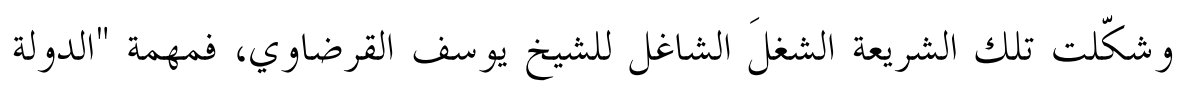

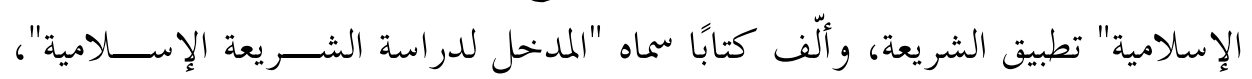

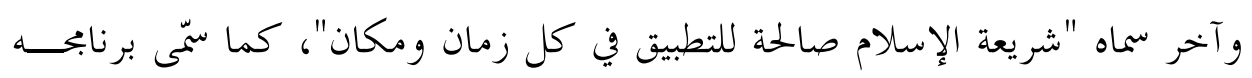
الشهير عبر قناة الجزيرة الفضائية "الشريعة والحياة".

و الشريعة هنا هي النظام الشامل؛ بما يعني من إعادة الطابع الإسلامي للحياة، وهو

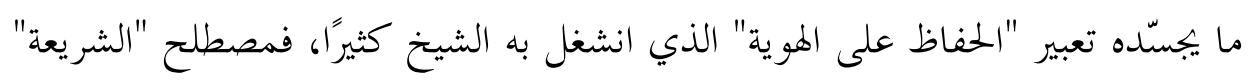

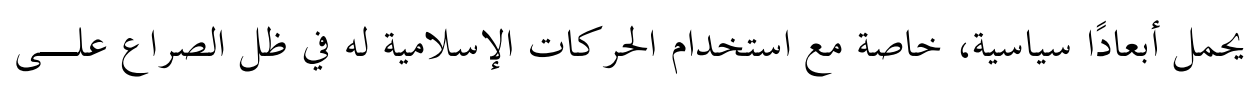
المرجعية.

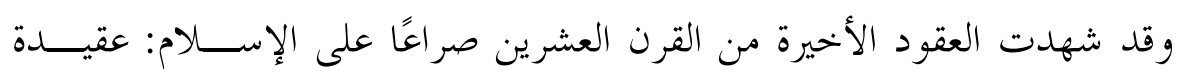

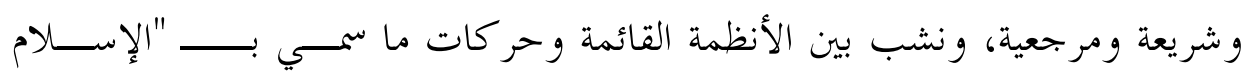

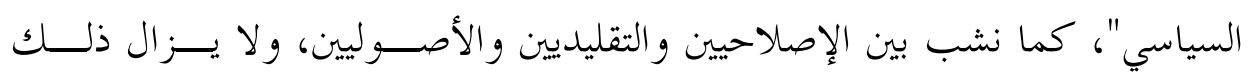

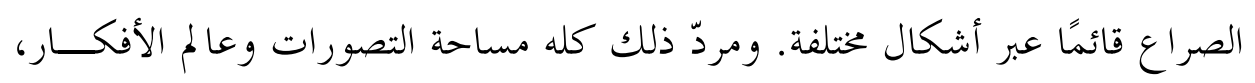

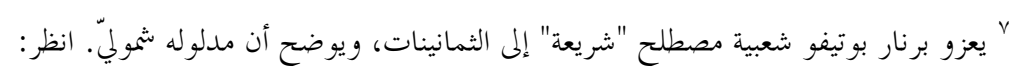

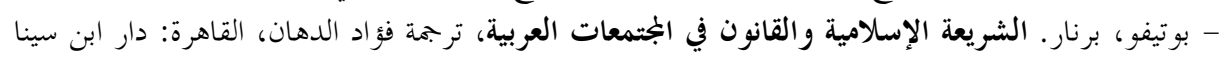

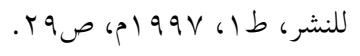


وفي القلب منه تقع مسألة المرجعية التي يتم التنازع فيها وعليها، وتحديــاًا في العـــالم السنّيُ.

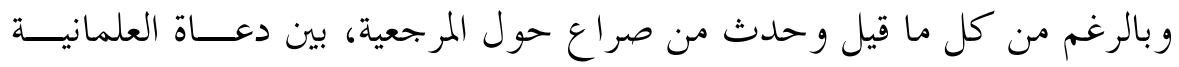

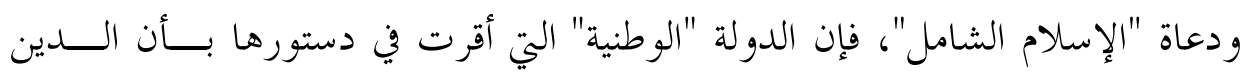

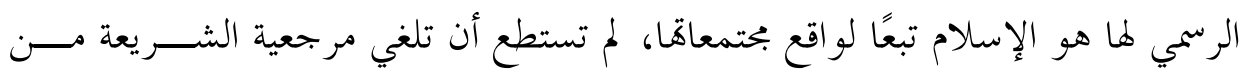

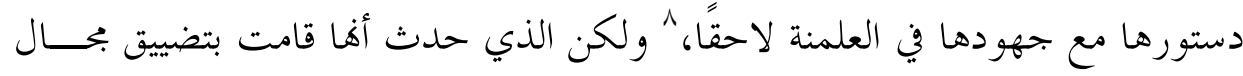

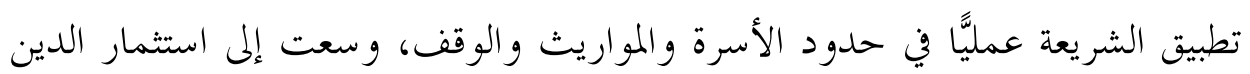

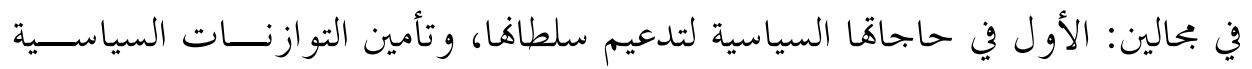

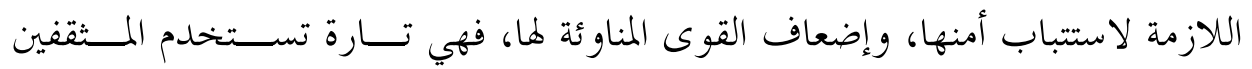

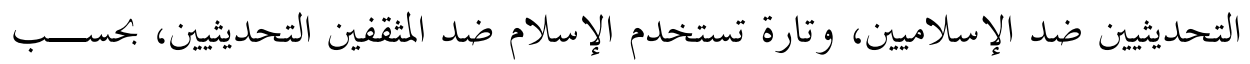
مؤشر التهديد الذي يشكله الخصم.

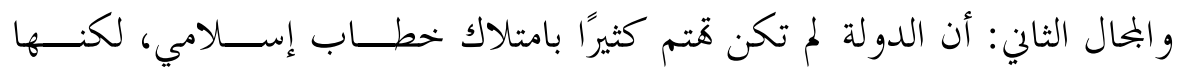

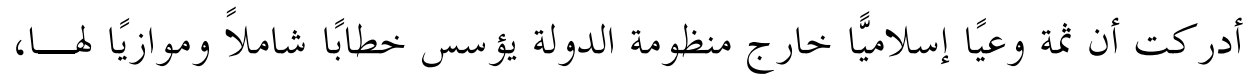

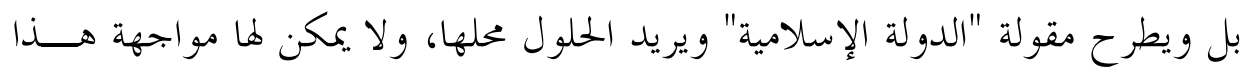

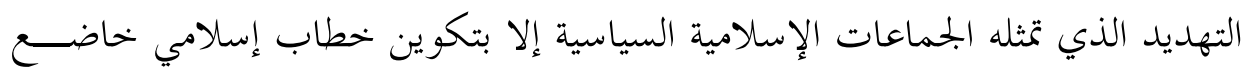

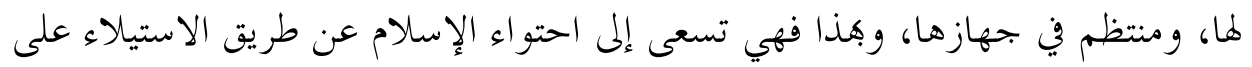

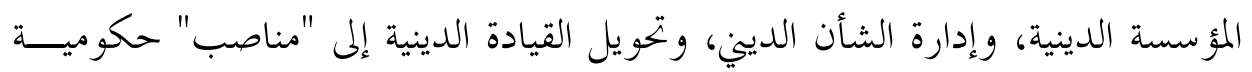

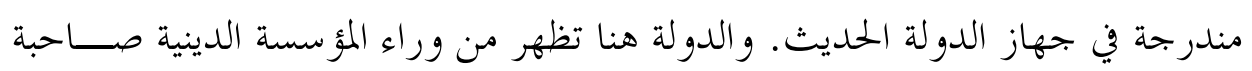

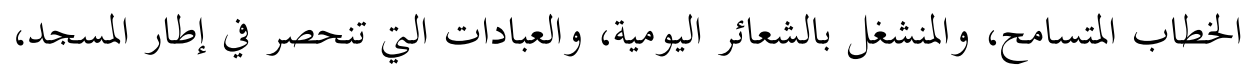

^ يقول شاخت: "وظل المبدأ القائل بأن الإسلام من حيث هو دين ينبغي أن ينظم الناحيــة القانونيــة في حيــاة

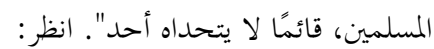

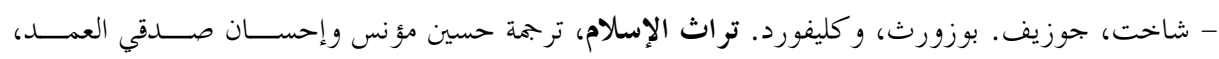

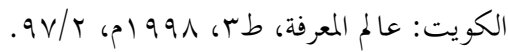


ومن ثم فهي تو اجه إسلام الحركات السياسية بإسلام المؤسسات الحكومية، على اعتبار أن ذلك مخالف لروح الإسلام الذي تحتويه هي في جهازها.

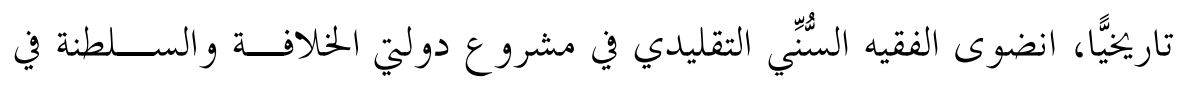

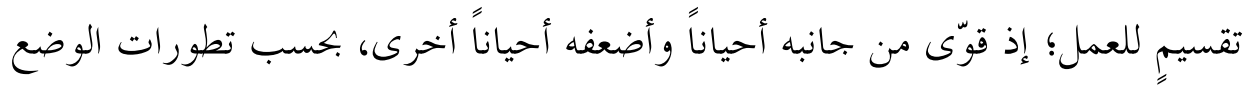

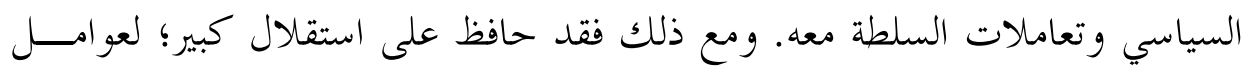

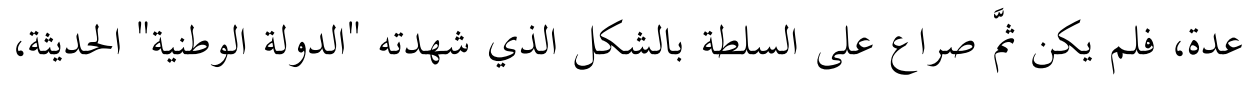

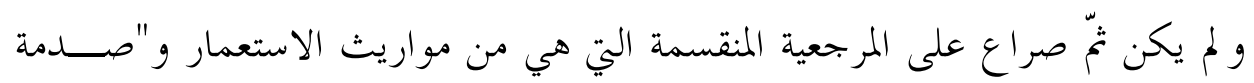

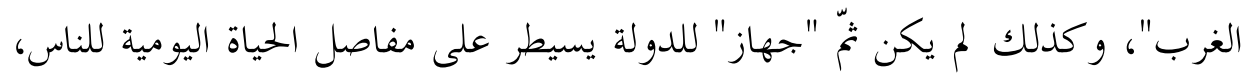

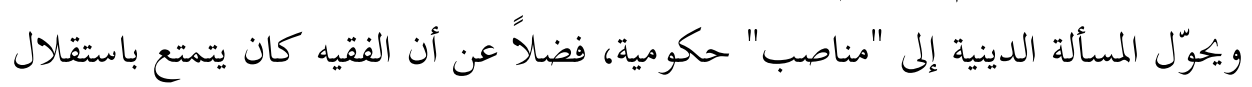

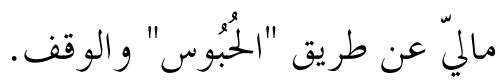

لكنّ التراكم التاريخي ومنهج التلقي العلمي، وتو الي العصور ومتغيرات الوقــائع،

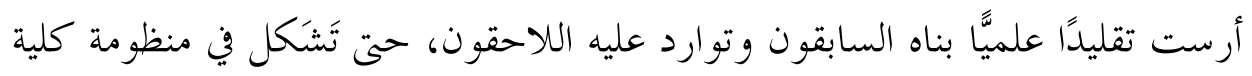

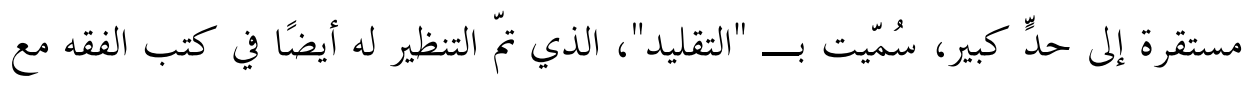

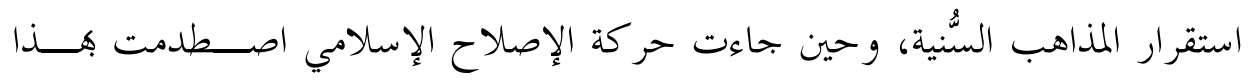

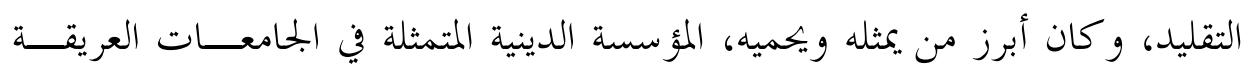
وخريجيها، كجامعة الأزهر وجامعة القرويين.

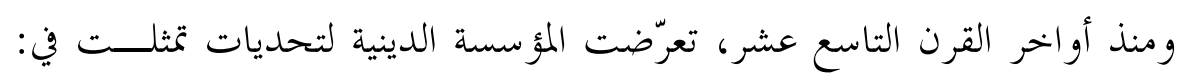

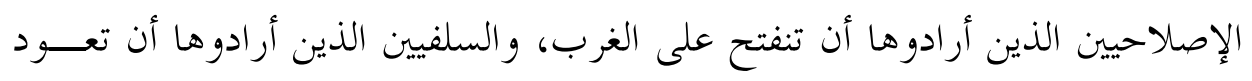

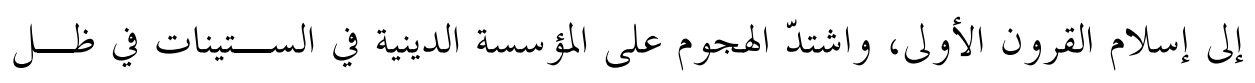


الصراع بين الإسلاميين والأنظمة، واستتباع الأنظمة للمؤسسة الدينيــة، أو ضــعفها

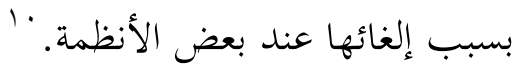
وبذلك ضعفت المؤسسة الدينية، مما هيَّأ لظهور مرجعيات موازية تخظى بجماهيرية

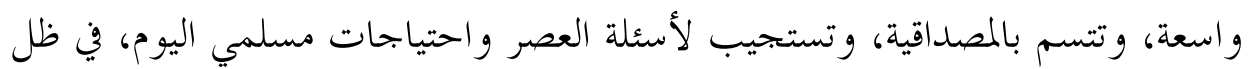

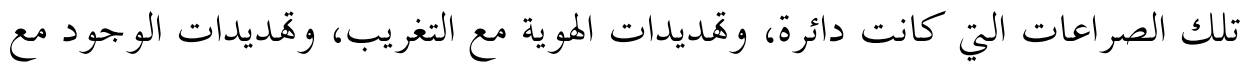
إلغاء الخلافة، وغياب الإطار الجامع للأمة، وقد كانت المؤسسة الدينية التقليدية متهمة

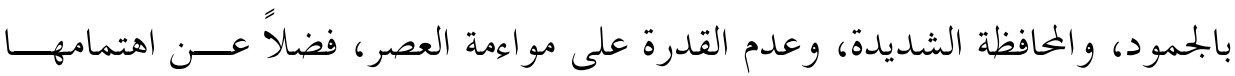
بالشعائر فقط.

وفي هذا السياق تظهر دلالة محاولة الإخوان المسلمين إنشاء مرجعية فقهية مستقلة عن الأزهر الذي ضعف كثيزًا، '" وتحول إلى "مؤسسة للدولة" بعد أن كان الان -تاريخيّاً

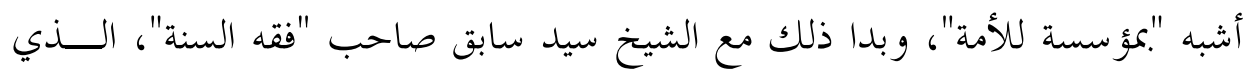

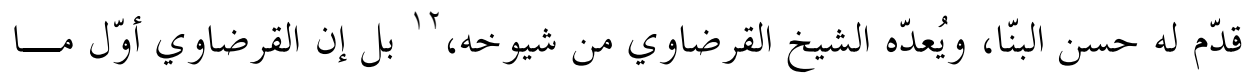

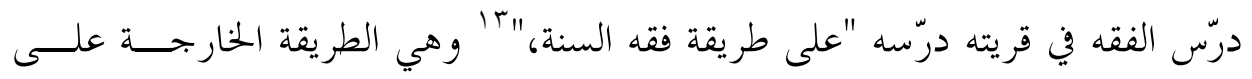

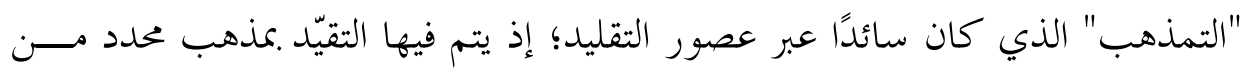

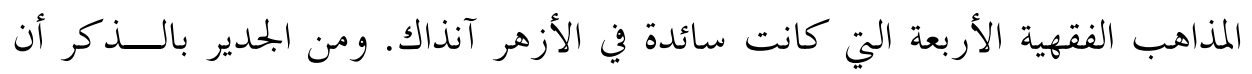

' 'يميز رضوان السيد بين عدة أنماط لعلاقة الدولة بالمؤسسة الدينية: النمط الأصولي، والنمط الخحايد، ونمط الجفـــاء. بين الدولة والمؤسسات الدينية. انظر: - السيد، رضوان. الأصولية الإسلامية: الفعالية والعلاقة بالدولة في العالم العربي، صحيفة الحيــاة اللندنيسـة،

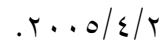

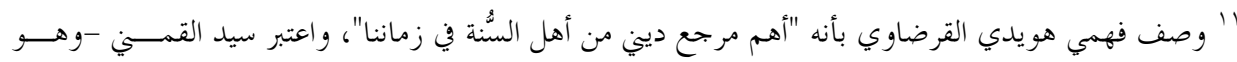

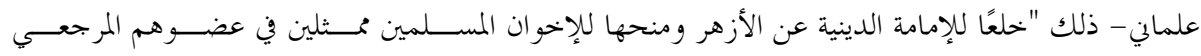
القرضاوي". انظر:

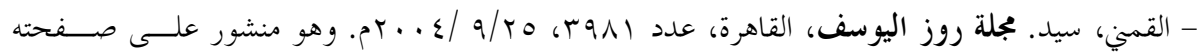
الشخصية على الإنترنت. : انظر

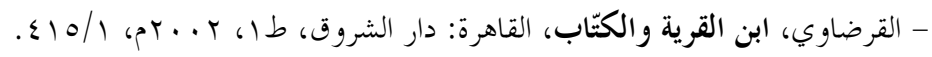

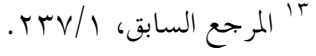




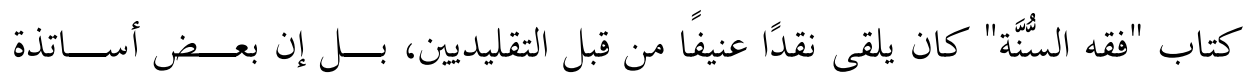

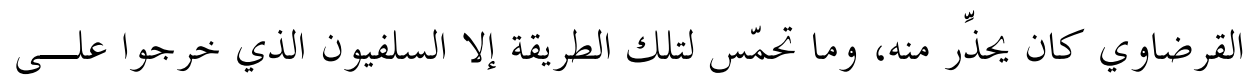

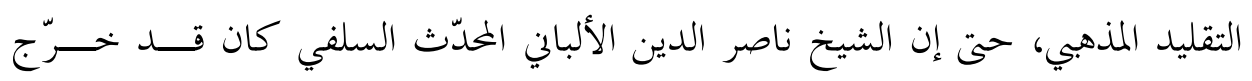

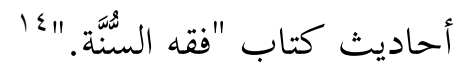

وتبدو فكرة المرجعية كذلك حاضرة في وعي الشيخ القرضاوي في ثنايا رفضــه

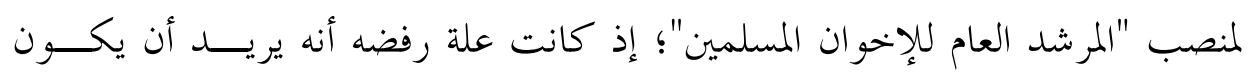

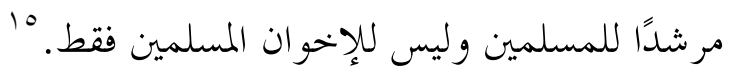

والمرجعية التي يتم الصراع عليها، تقوم في الإسلام السُّني -في تكوّها ومســـارها

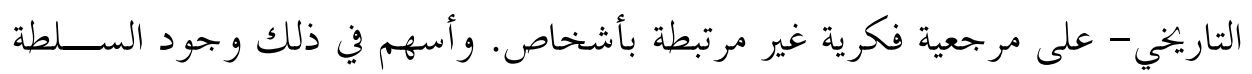

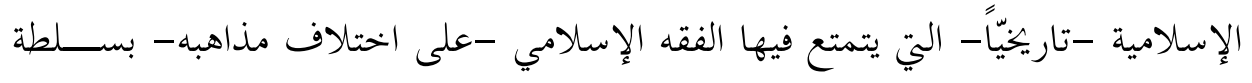

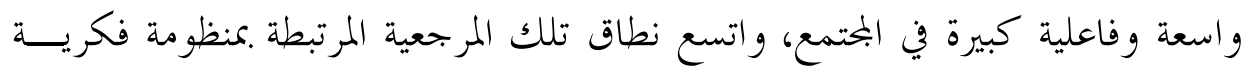

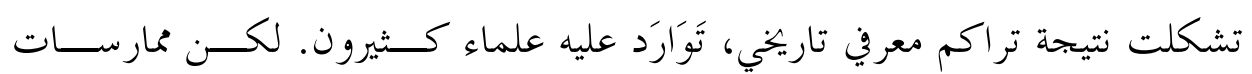

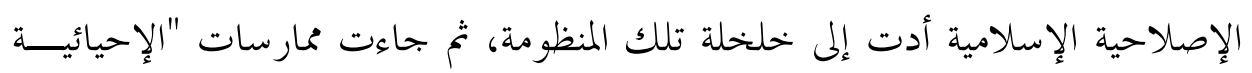

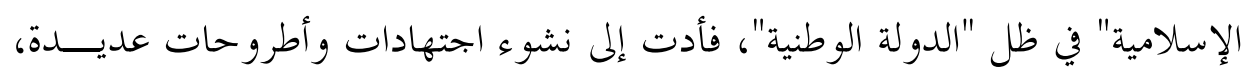
بعضها عنيف.

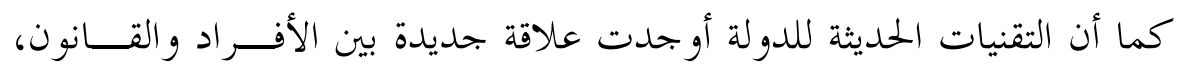

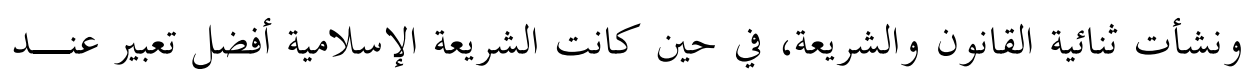

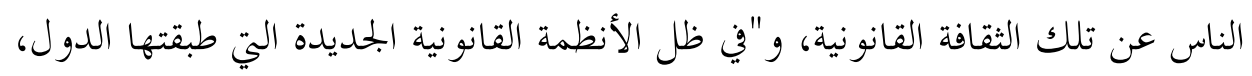

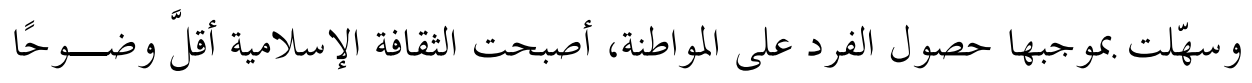

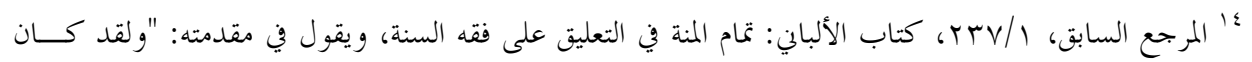

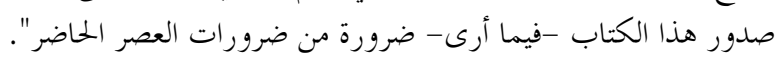

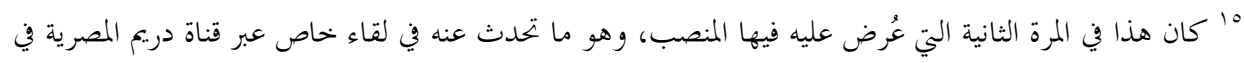

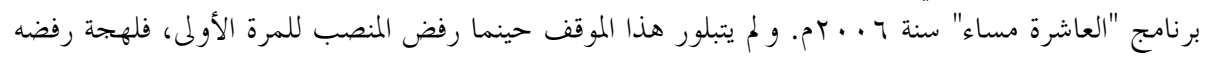


في المحالات العامة التي تشرف عليها الدولة، وفقدت الشريعة جانباً من قوقا كمرجعية

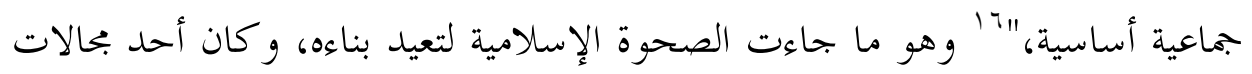

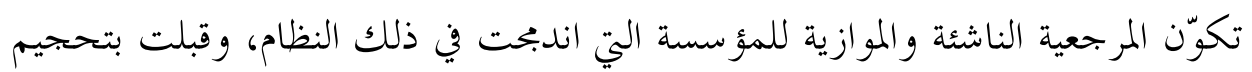
دورها، و الاختصاص بالشعائر، حتى إن التسمية التي أطلقتها بعض الدول - كســـوريا

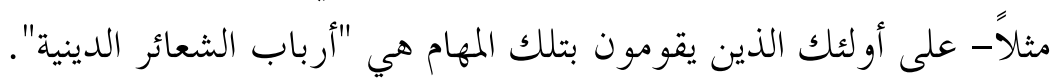

\section{ثانياً: القرضاوي ... بدايات النشأة ومسارات التكوين}

نشأ القرضاوي في قرية متواضعة من قرى الريف المصري، كان يغلــبـ عليهـــــا

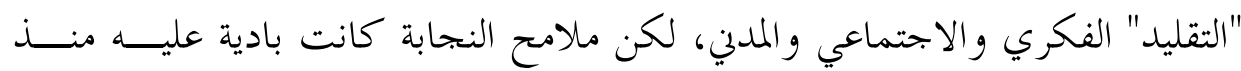

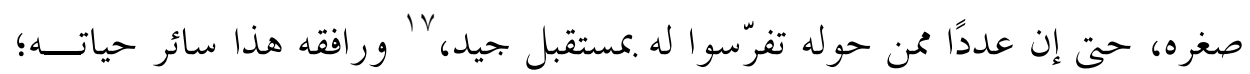

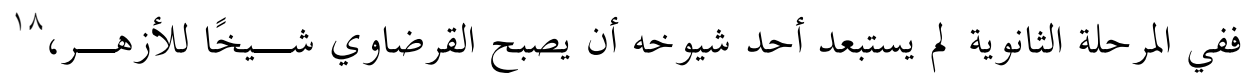

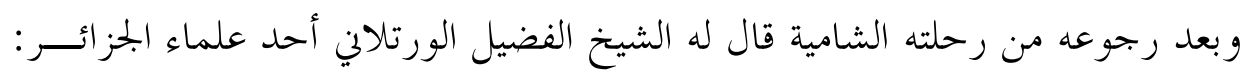

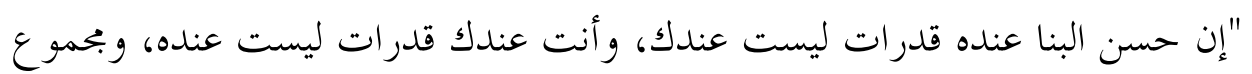

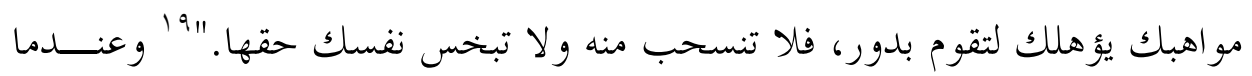

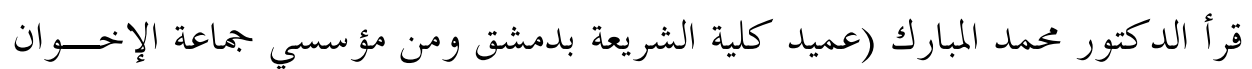

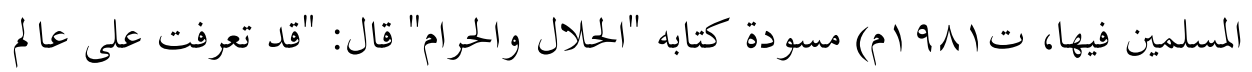
جديد له مستقبله إن شاء الله. "•r

إن العامل الأول من مؤهلاته الشخصية ماثلّ في نبوغه الذي بدت ملامحه مبكــــة

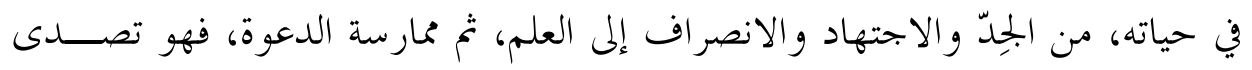

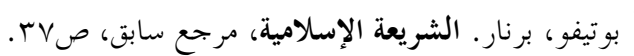

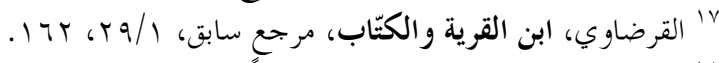

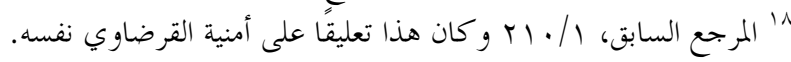

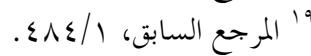

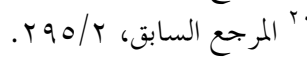


للقيادة مبكرًا في مناسبات عدة، 'ب و كان زملاؤه في المعهد يحتكمون إليــه، ويعدّو نـــه

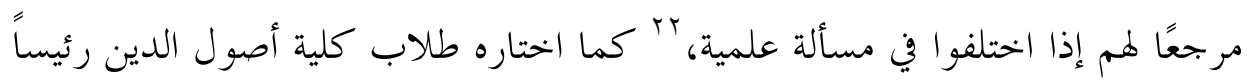

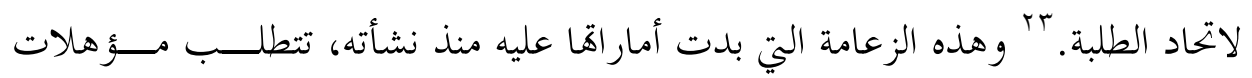
كانت متو افرة فيه؛ من القدرة على مخاطبة العقل الجمعي للناس، والمقدرة الخطابية على لى لئل التأثير فيهم واستمالتهم. ومما يدخل في المؤهات الشخصية أيضًا، تلك النوازع "غير التقليدية" التي بــــت لديه، و ونمت بعد ذلك لعو امل عديدة. ومما يلفت النظر، أن القرضاوي تعرّف مبكرًا على الإمام المتكلم الفقيه الصـــوفي

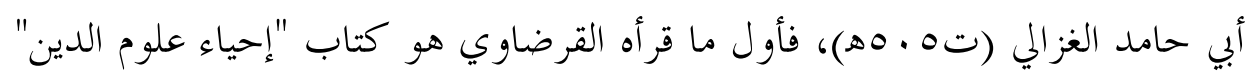

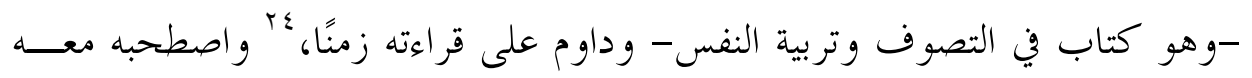

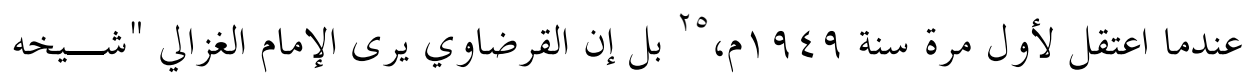

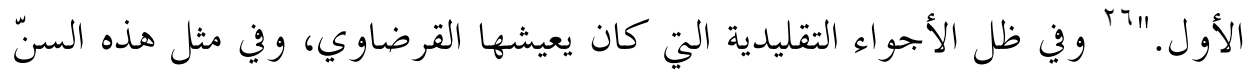

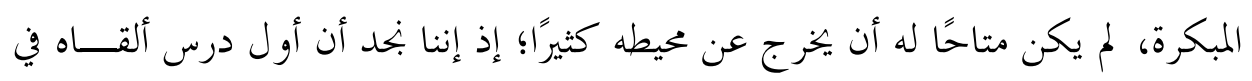

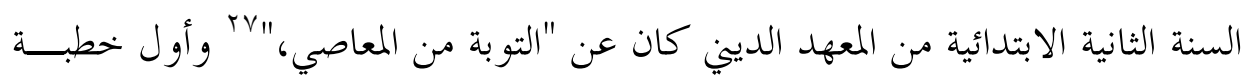

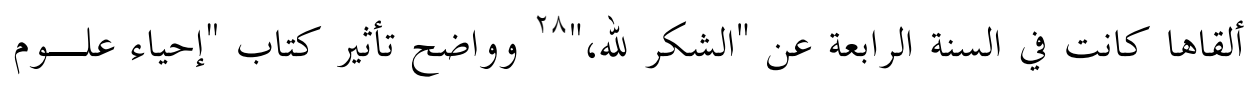
الدين" فيهما، من حيث الموضوع و المضمون. و استمر هذا التوجه الوعظي حتى المرحلة

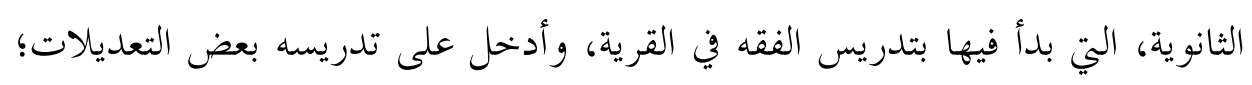

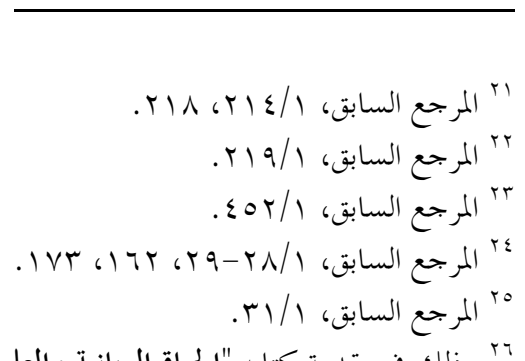

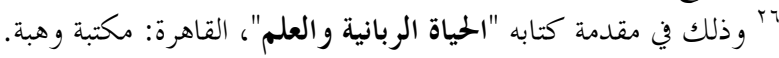

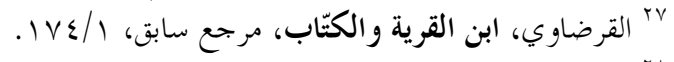

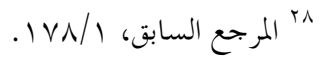


إذ ابتعد عن الحشو والتطويل، وتبنى التيسير و التخفيف، و لم يلتزم بمذهب أهل القريـــة

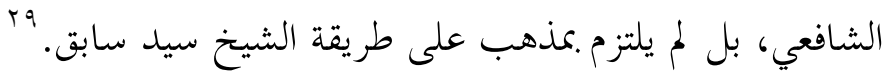

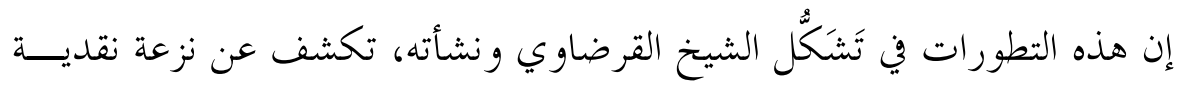
واضحة، ابتدأت من نقده لكتاب "إحياء علوم الدين" أثناء قراءته له؛ إذ كان يعترض

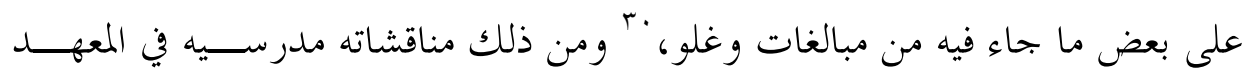
الديني التي استمرت لاحقًا إلى الكلية، فهو يصف نفسه فيقول: "أنا بطبيعي أحب أن أن

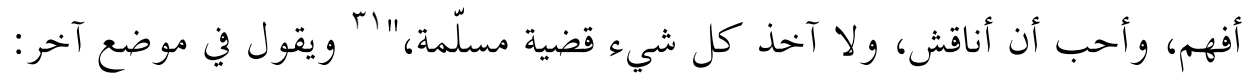
"و كنت على فطرتي وطريقتي أناقش وأسأل في كل ما لا يقتنع به عقلي أو يطمئن إليه

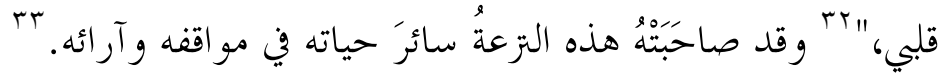

إلى جانب التزعة النقدية، ثمة نزعة نحو المعاصرة، وهي التي بدت من طريقتــه في تدريس الفقه في المرحلة الثانوية، فلم يكن مرتاحًا للكتب المؤلفة في علم الفقه، وطريقة

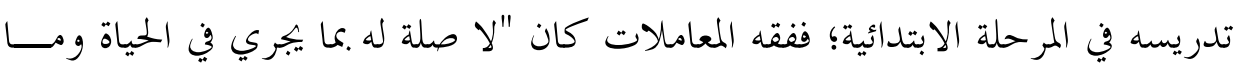

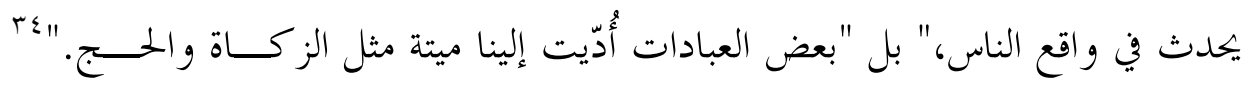

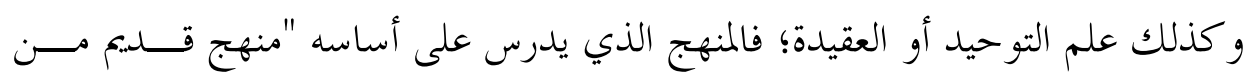
آثار عصور التراجع والتخلف في الحضارة الإسلامية، وهو يقوم على افتراضات معينة

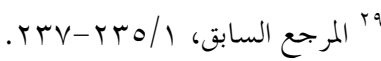

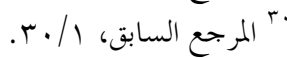

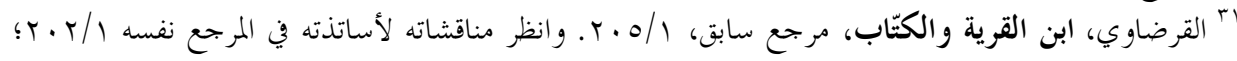

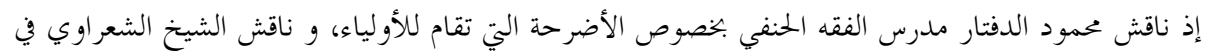

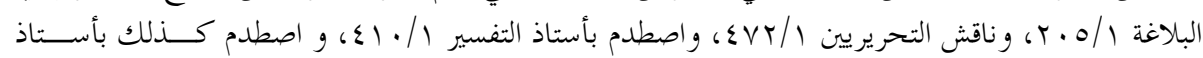

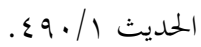

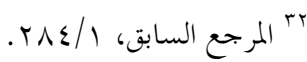

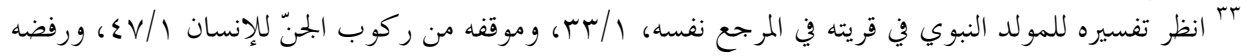

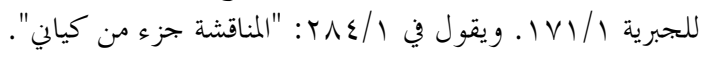

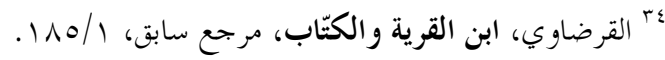


وفلسفة معينة لم تعد موجودة أو مؤثرة في حياتنا العقلية ... وهي مكتوبـــة بلغـــة لا تلائم هذا العصر، و لا تعالج مشكلاته العقلية." وهب و كذلك التفسير.

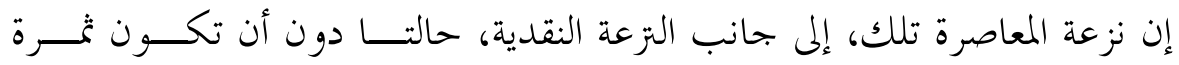

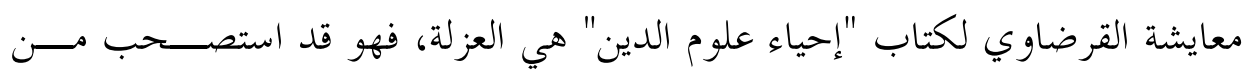

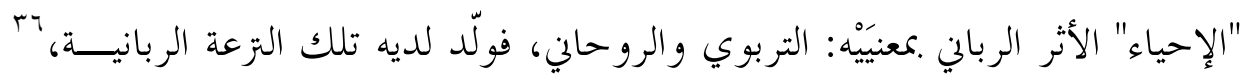

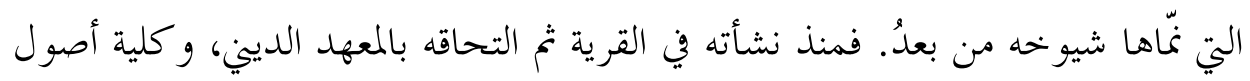

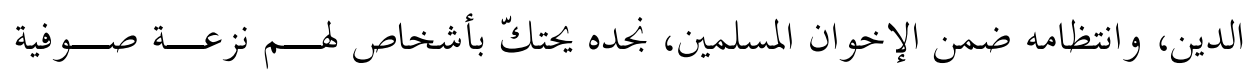

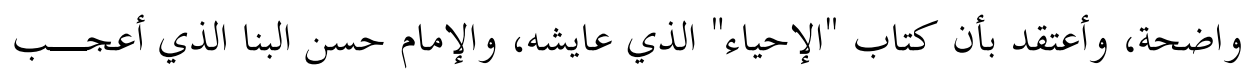

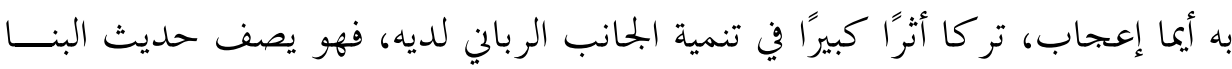

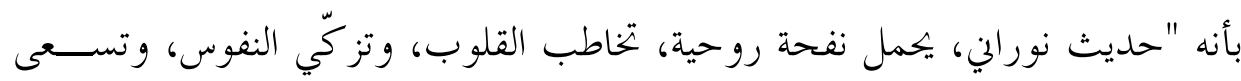

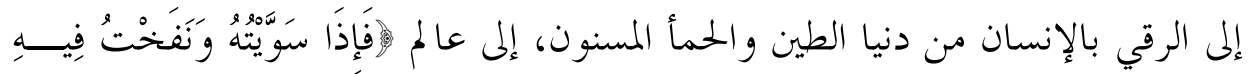

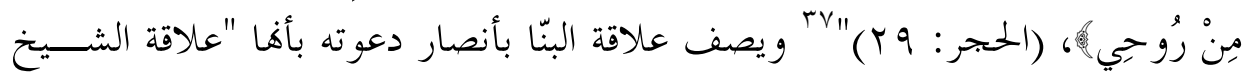

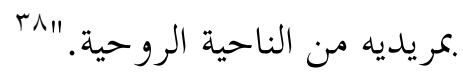

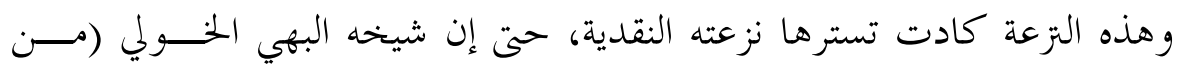

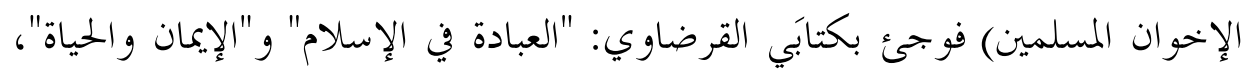

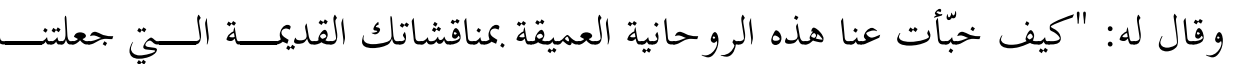

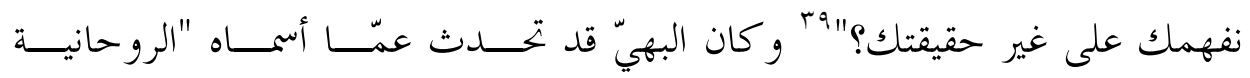
الاجتماعية" في كتابه "تذكرة الدعاة"، وهو ما أفاد منه القرضاوي الذي انتظم معه في لئي

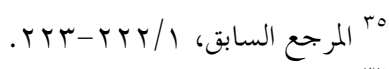

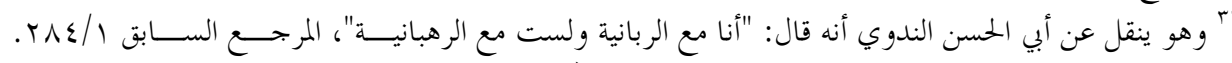

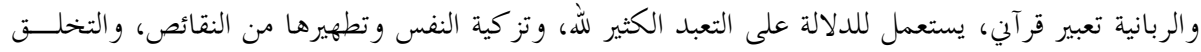

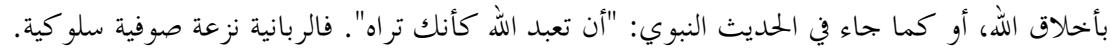

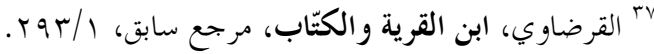

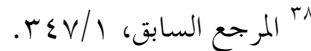

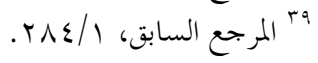


"كتيبة الذبيح"؛ إذ كان همّ البهي فيها توجيه الطلبة توجيهًا روحيَّا وسلو كيًّا. “؛ وحين

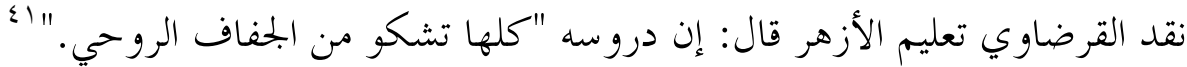
وممن تأثر هـم القرضاوي في هذه التزعة سعيد رمضان، صهر البنا، الذي وصــفه

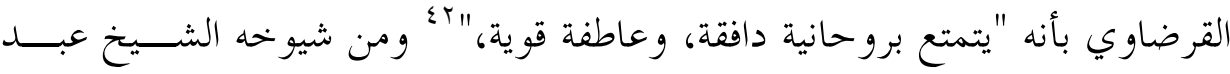
الحليم محمود (أحد شيوخ الأزهر، تخرج في فرنسا) "وقد كان رجالاً متصوفًا: فكـــرًا

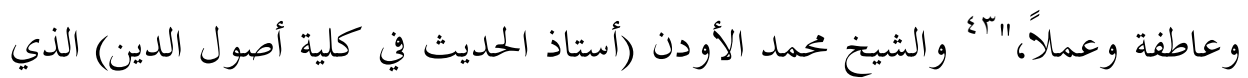

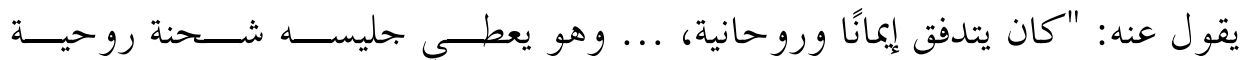

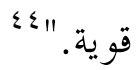

لم تكن المؤهلات الشخصية وحدها كافية، ما لم تتو افر لها البيئة المساعدة علــى تنميتها واستثمارها، وهو ما توافر للقرضاوي حين التحق بحركة الإخوان المســلمين، فابجذب إلى مؤسسها حسن البنا منذ وقعت عينه عليه، واستمع إليه. فالقرضاوي الذي كان يتململ من النمط التقليدي في قريته، صادف مع حسن البنا حديثًا جديدًا أصيلاً

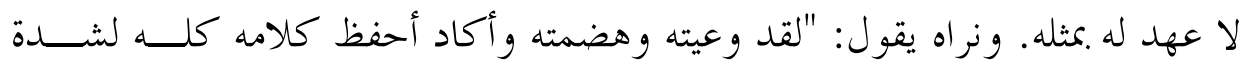

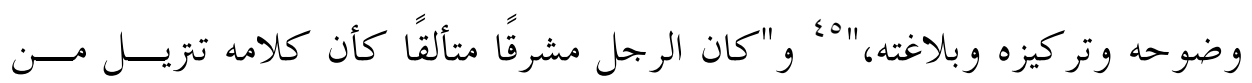

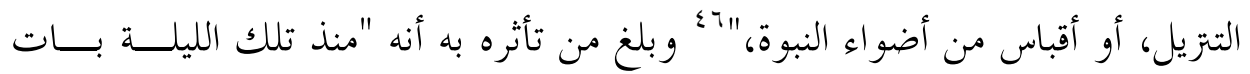

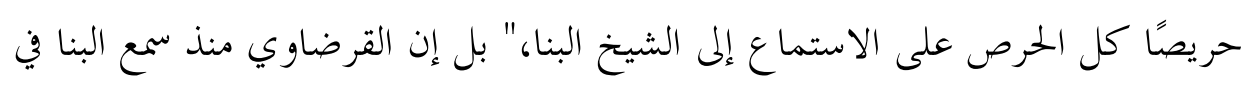

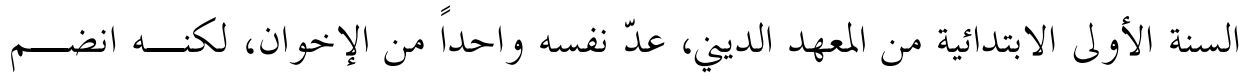

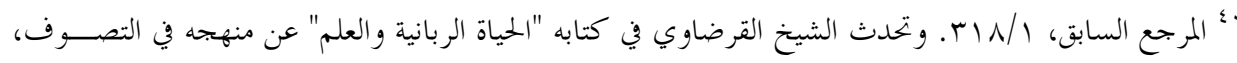

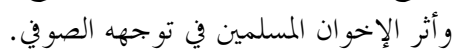

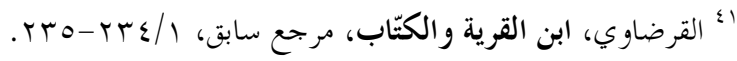

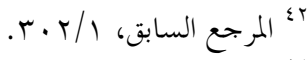

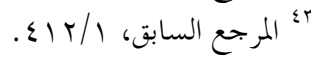

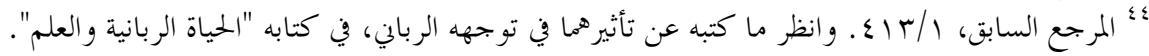

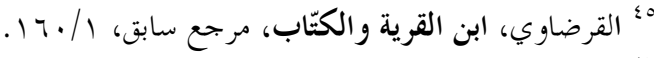

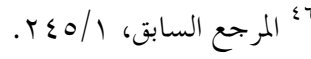


إليهم في السنة الرابعة الابتدائية. V؛ و كان يحرص دوماً على اللقاء بالبنا لشدة تعلقه بـــهـ

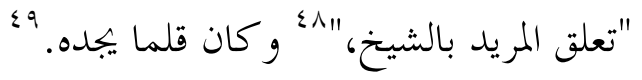

و وفي الحقيقة أن التحول الذي طرأ على القرضاوي الذي كان يقرأ "إحياء علــــوم

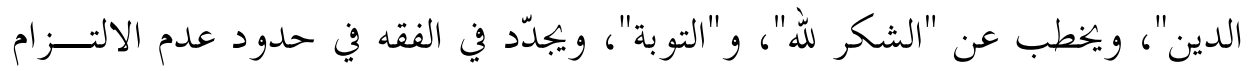

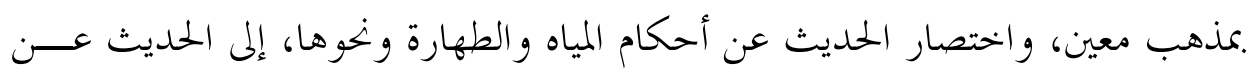

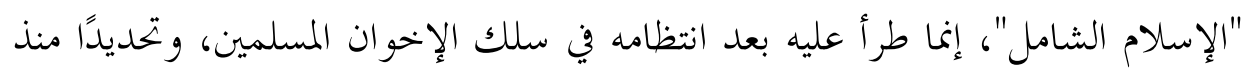
أن استمع إلى حسن البنّا. و القرضاوي نفسه يقرّ بذلك حين وقف "وقفة تأمل مع الإخوان"؛ إذ رأى أنــــ

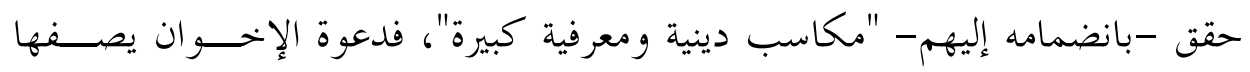

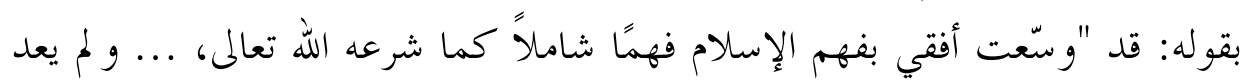

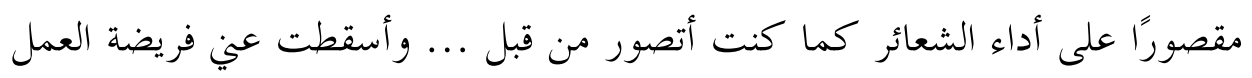

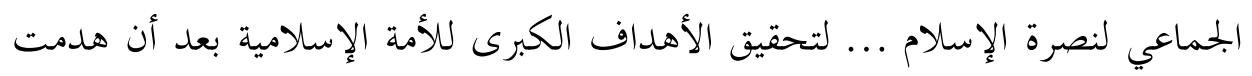

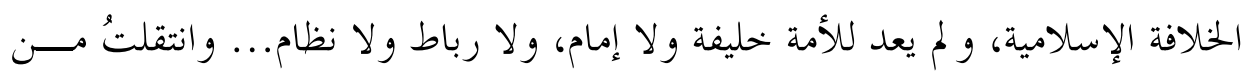

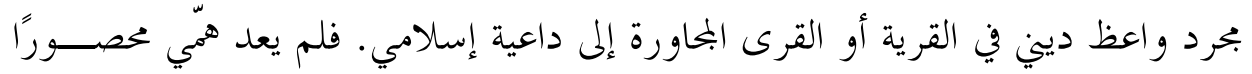

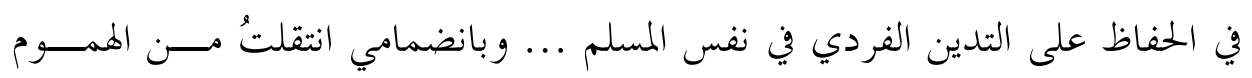

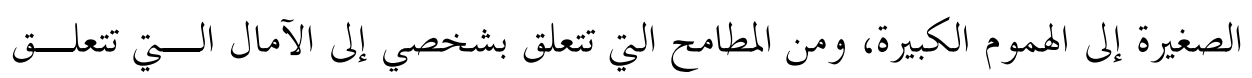

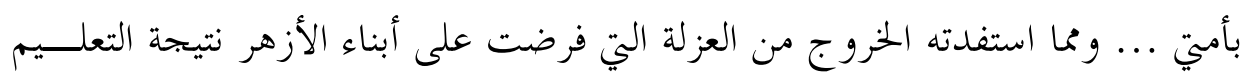
المزدوج." بامي "ن أي: الديني و المدني.

ويتبدى من أطروحة "النظام الشامل" كل مقولات الخطاب الإسلامي المعاصــر،

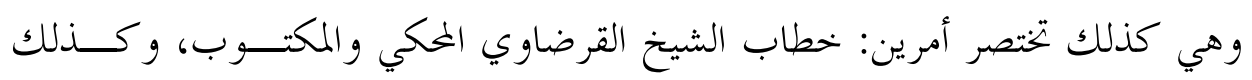


دوره ونشاطه العملي، وهو ما يعكس مدى التحول الكبير منذ أن استمع إلى البنّا، ثم انضمامه إلى دعوته بعد ثلاث سنوات.

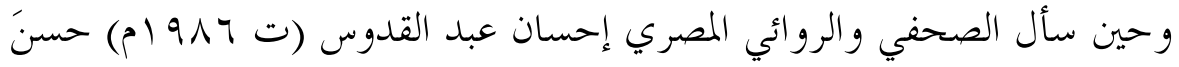

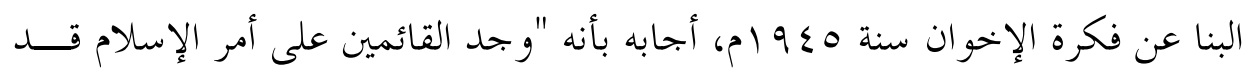

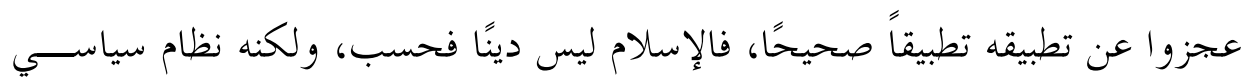

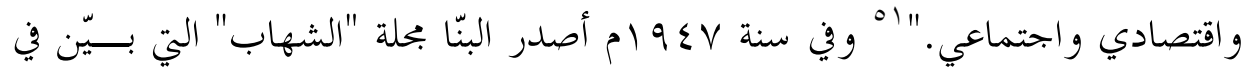

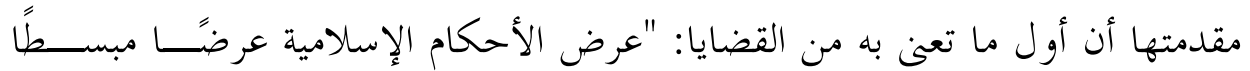

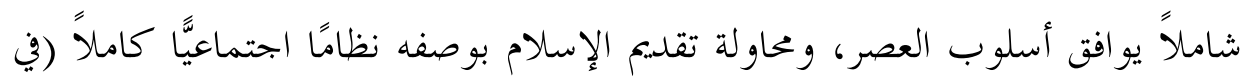

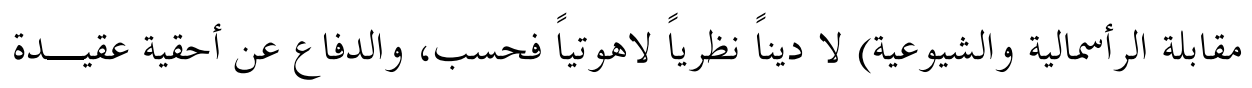

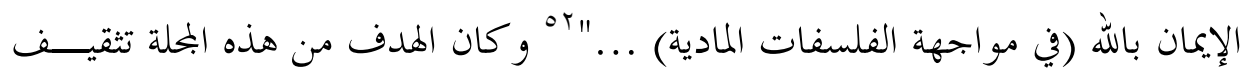

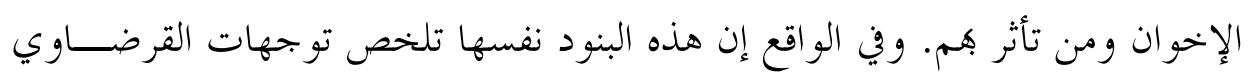

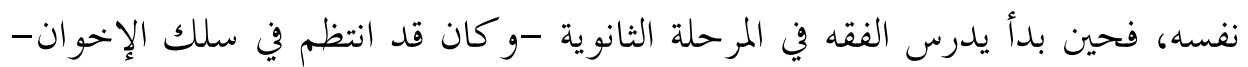

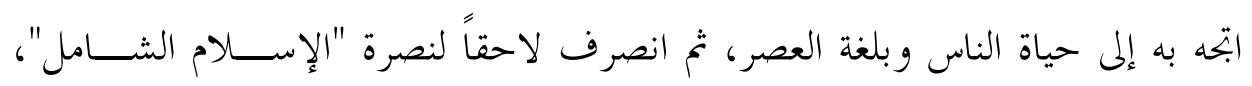

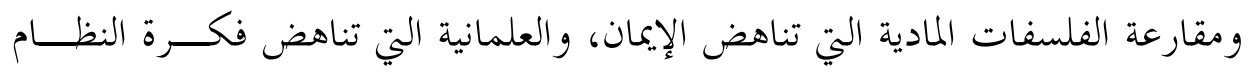
الشامل.

و لم يقتصر التأثر على البّّا وحده، فهذه الأفكار أضحت فلسفة جماعة عريضــة،

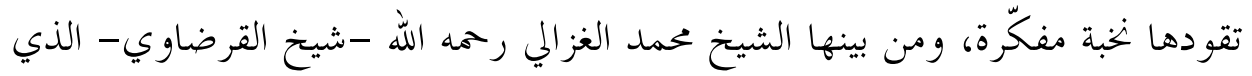

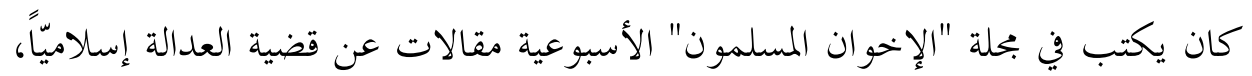

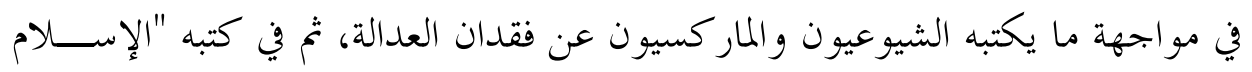

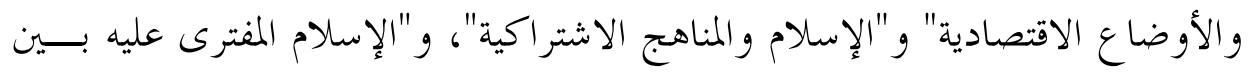

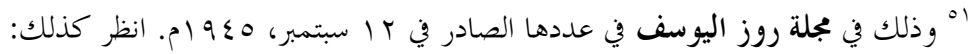

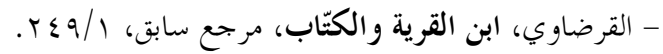

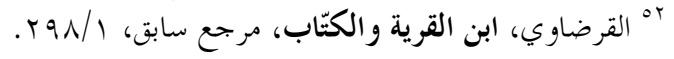




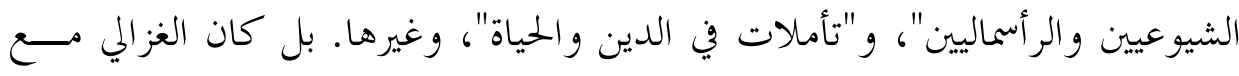

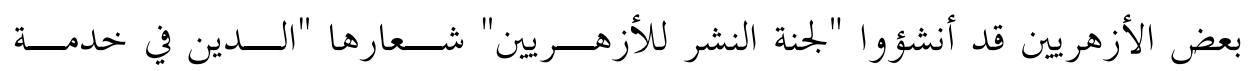

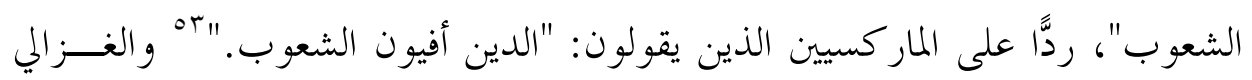

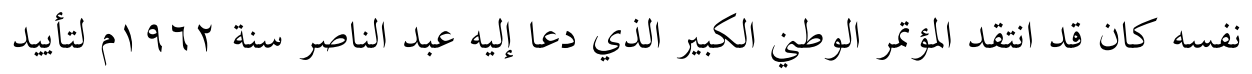

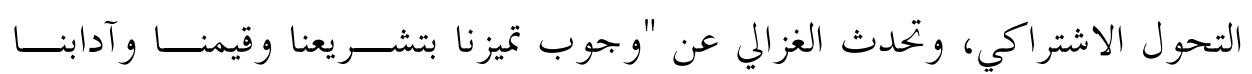

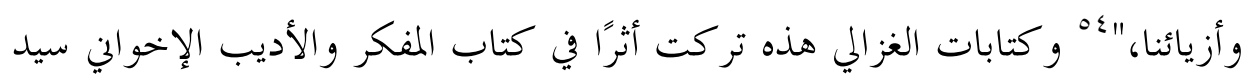
قطب أيضًا "العدالة الاجتماعية"، فقد كانت مراجع مهمة استند إليها.

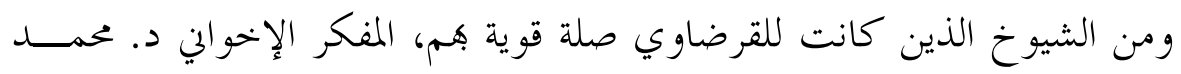

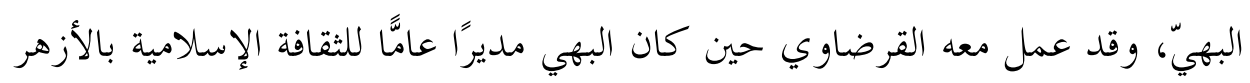

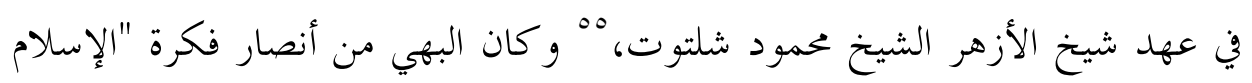

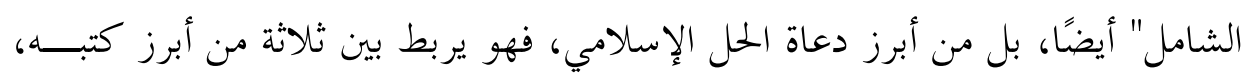

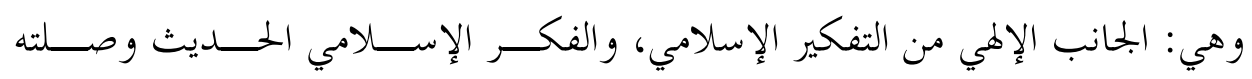

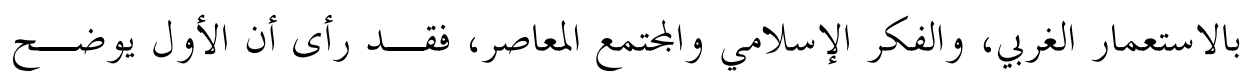

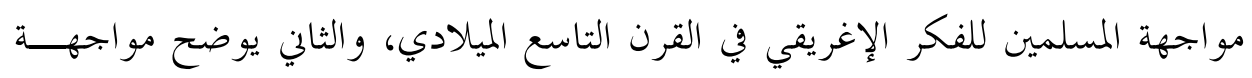

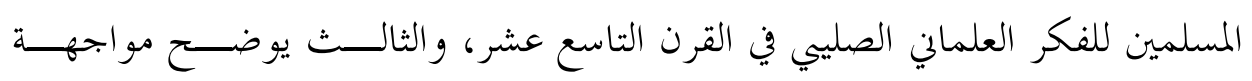

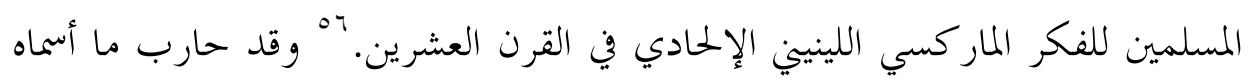

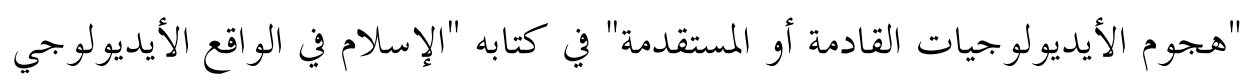
المعاصر" الذي صدر سنة 971 ام، أي قبل كتاب القرضاوي "الحلول المستوردة".

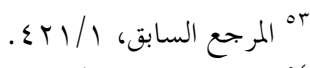

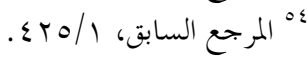

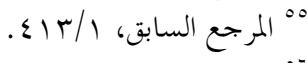

$$
\begin{aligned}
& \text { 10 }
\end{aligned}
$$

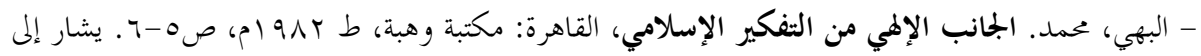

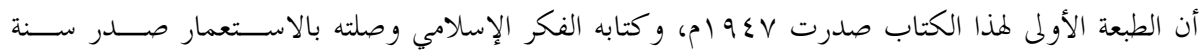


و كان أحد أهم بحليات فكرة "النظام الشامل" هو الاهتمام بالمسألة الوطنية، الـــي

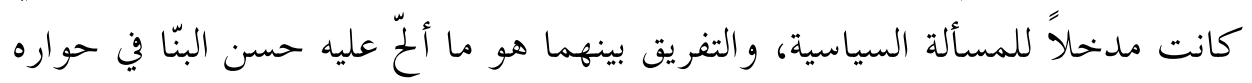

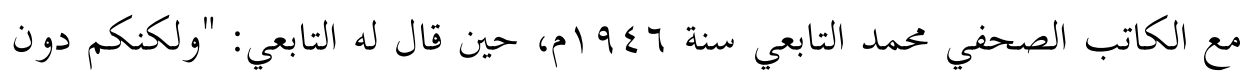

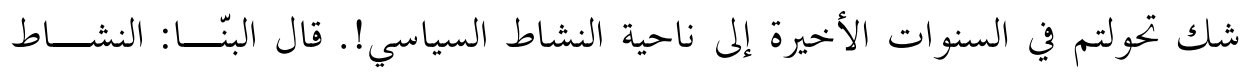

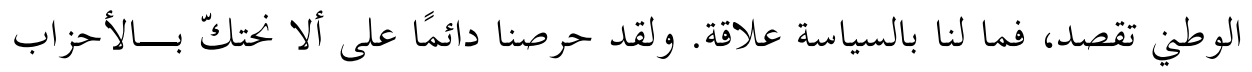

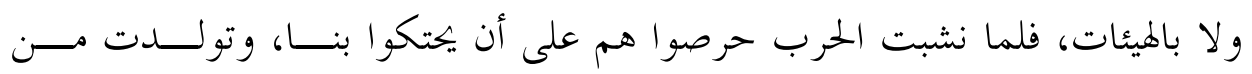

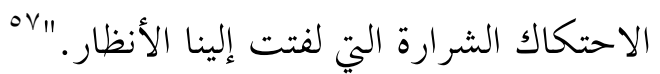

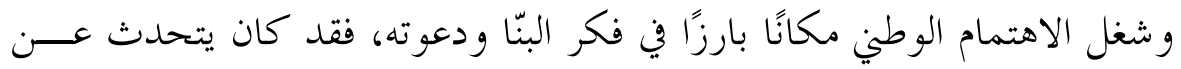

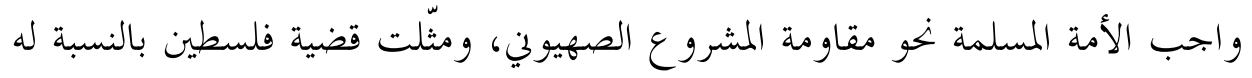

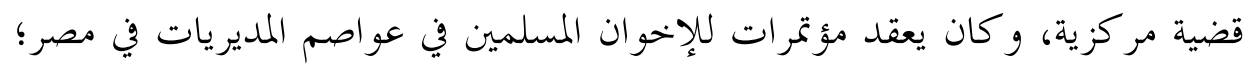

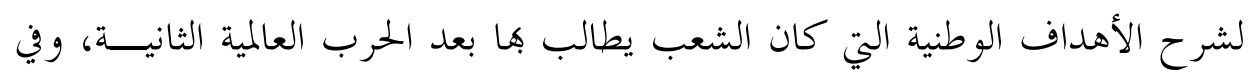

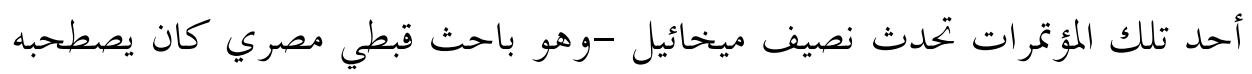

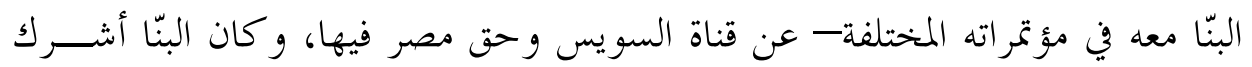

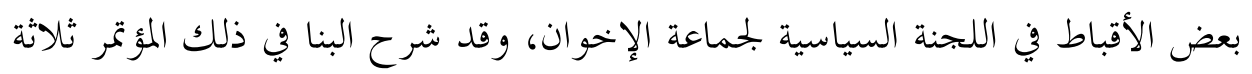

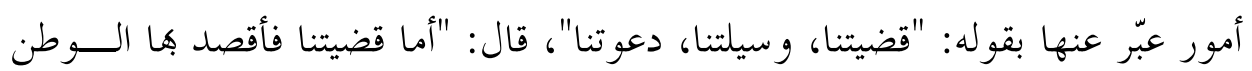

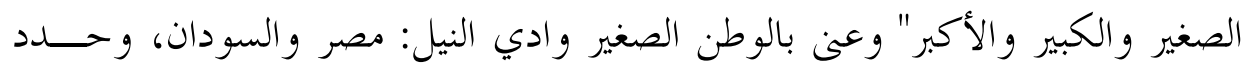

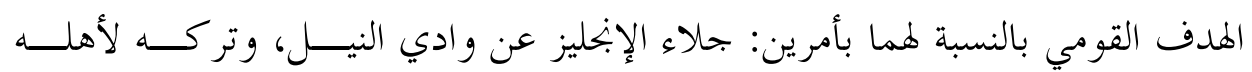

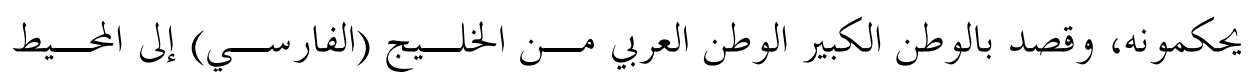

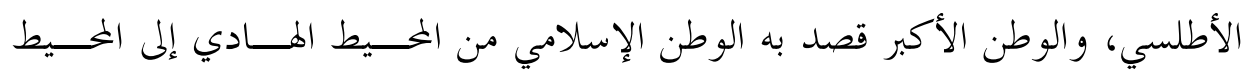

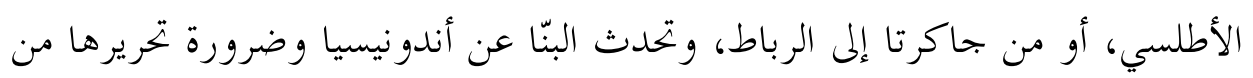
الاستعمار الهولندي، وضرورة تحرير تونس والجز ائر ومر اكش (أي المغرب). 
أما وسيلتنا فإنها تبدأ بالمفاوضة، إلى المقاطعة، إلى الجهاد إن لمُ تُجْـــدِ الوســائل الأخرى.

وقد أوردتُ هذا الكلام -على طوله- لشدة أهميته في عمــق الــوعي الـــوطني

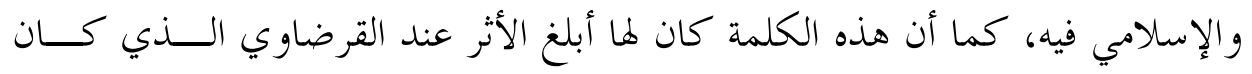

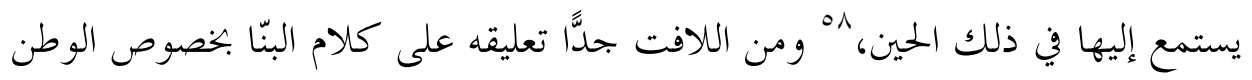

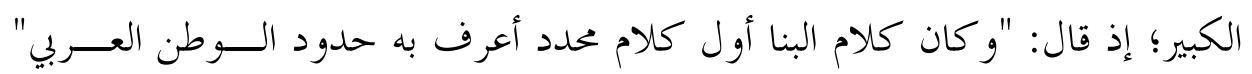

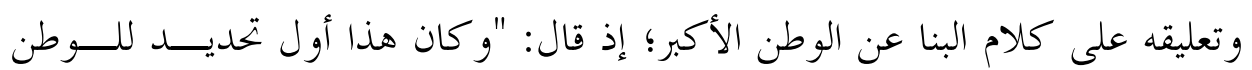
الإسلامي أسمعه." وتعليفه كالام البن

وما كان الإلحاح على المسألة الوطنية قاصرًا على المؤتمرات، فالبنا كان يســتمر

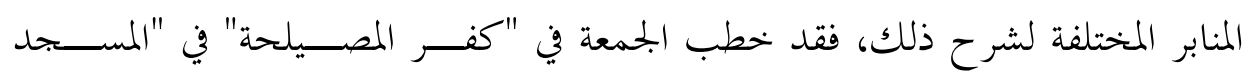

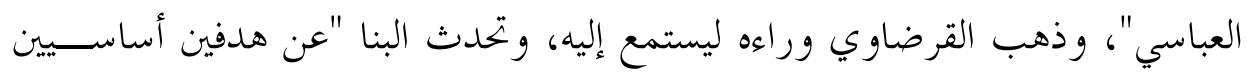

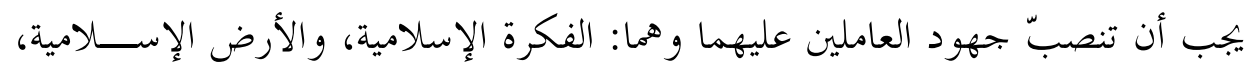

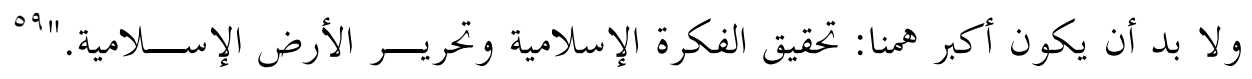

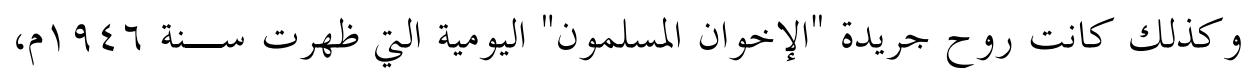

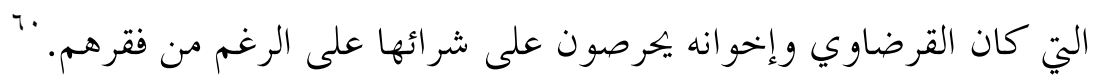

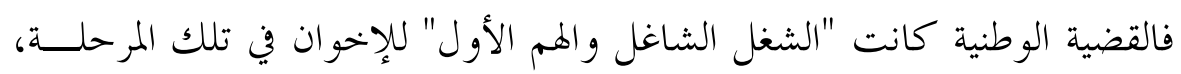

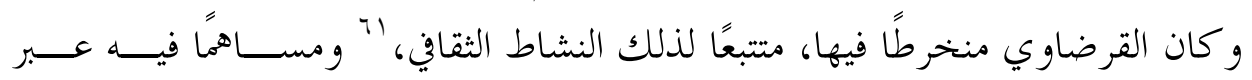

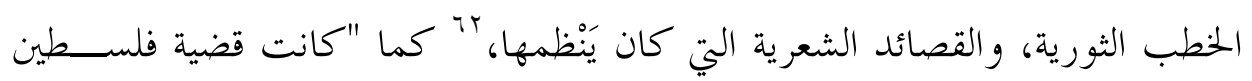

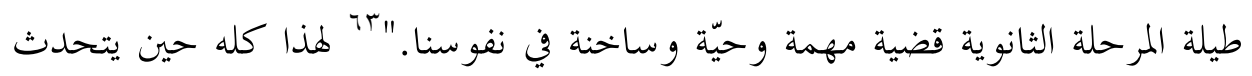

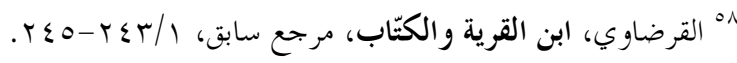

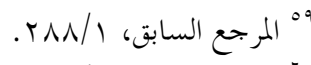

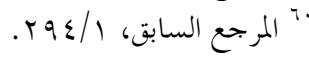

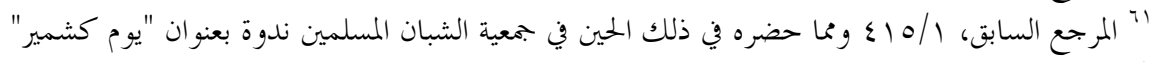

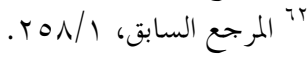

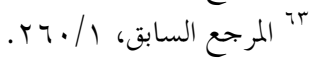


القرضاوي عن مكاسبه من الإخوان المسلمين، يقول: بانضمامي إلى دعوة الإخـــوان

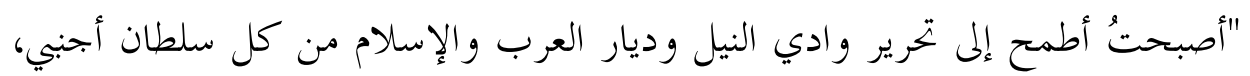

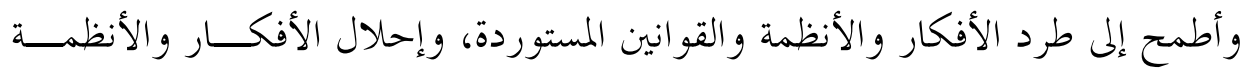

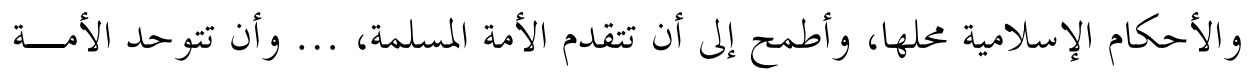

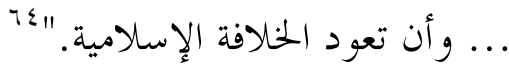

إن قرضاويّ الإخوان ما عاد قرضاوي القرية والكتّاب، فقرضاوي القرية كـــان

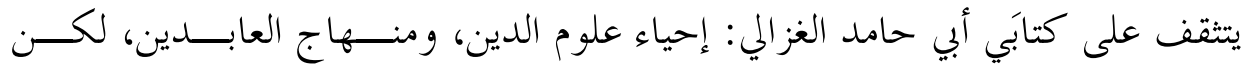

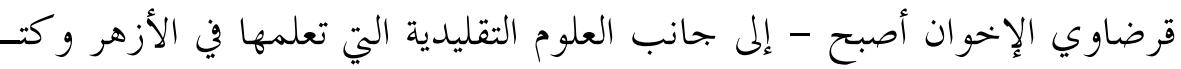

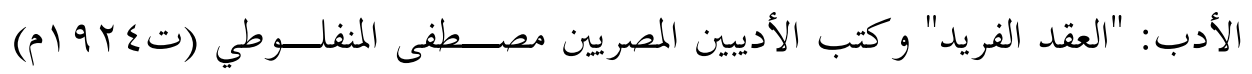

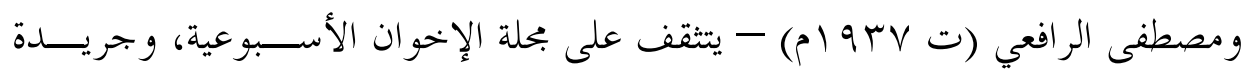

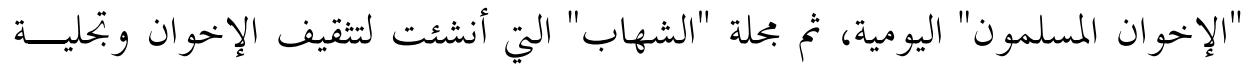

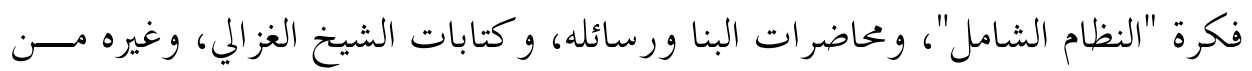

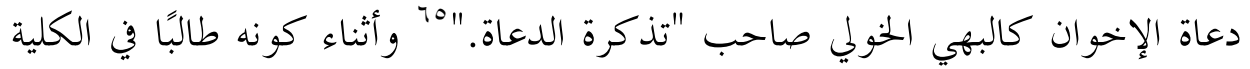

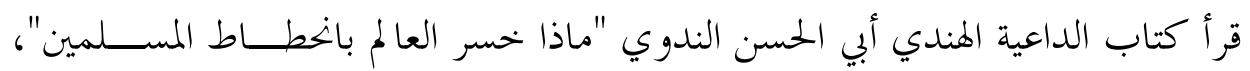

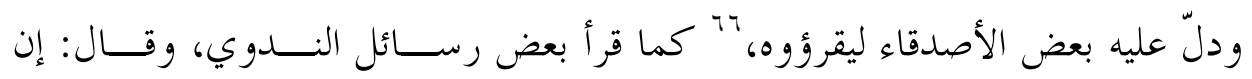

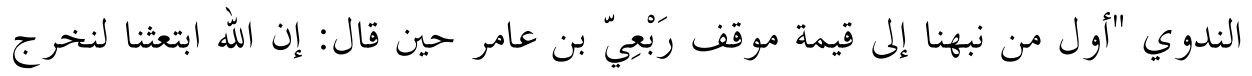

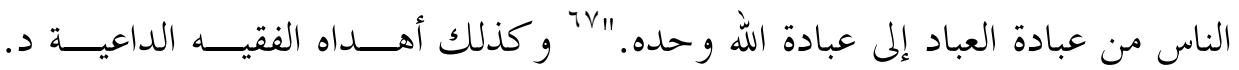

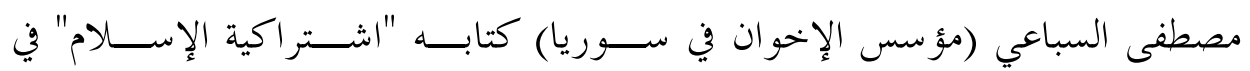

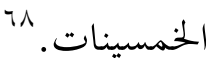

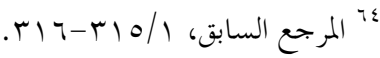

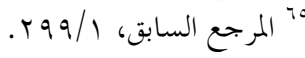

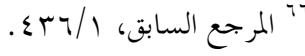

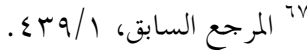

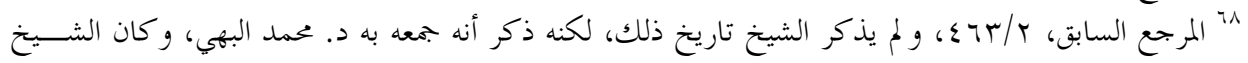

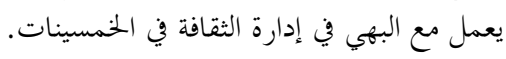


لقد شكّلت بحلة "الشهاب" الإخو انية رافداً مهمًّا لبناء ثقافة الإخوان، وتعميــق فكرة "النظام الشامل"، و كذلك بناء شبكة علاقات ضمن باب أسمته "سجل التعارف

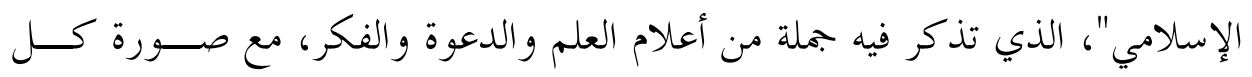

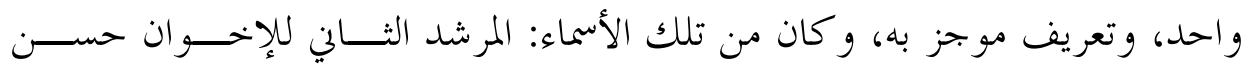

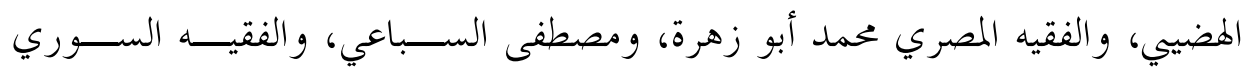

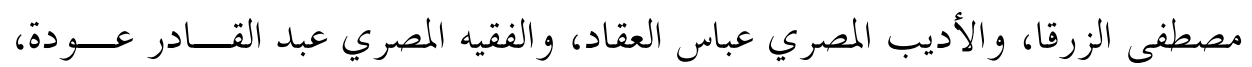

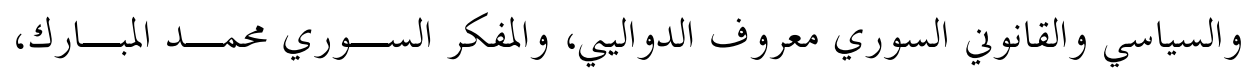
وغيرهم، و كان لهؤلاء إسهامات فكرية وفتهية مهمة ومؤثرة.

وكانت أول رحلة له إلى بلاد الشام في عام 90 19م، بأمر من حســن الهضــيي

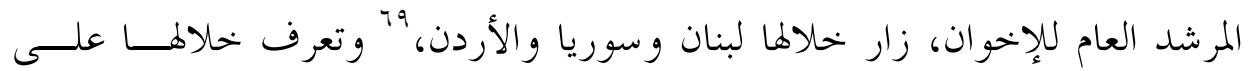

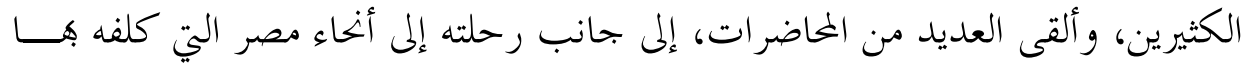

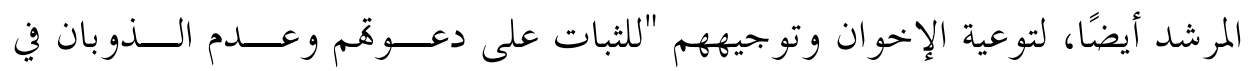

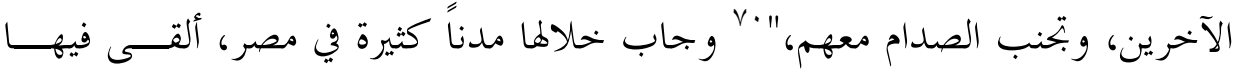

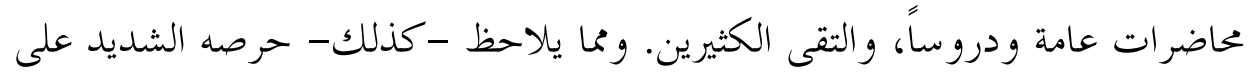

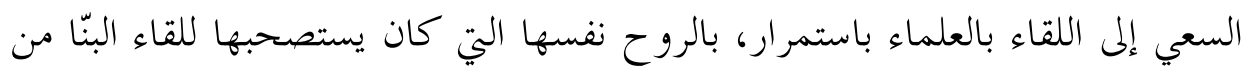

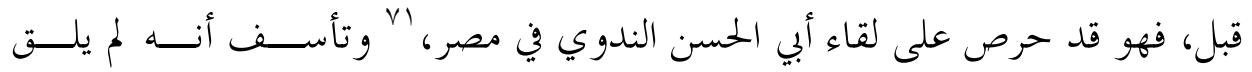

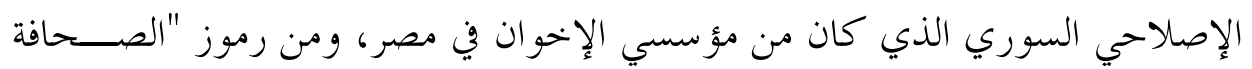

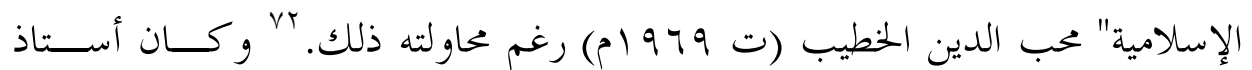

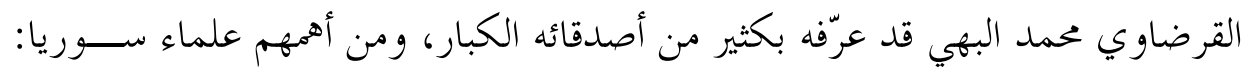
مصطفى السباعي، ومصطفى الزرقا، ومحمد المبارك، ومعروف الدو اليب، وهؤلاء جميعًا

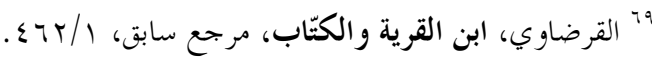

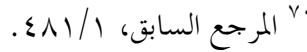

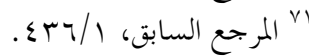

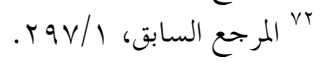


مع محمد البهيّ ساهمو ا في لجان تطوير الأزهر، و واقترحو ا تدريس طلاب الأزهر مــادة

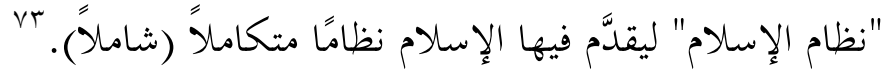

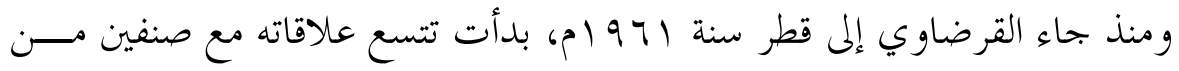

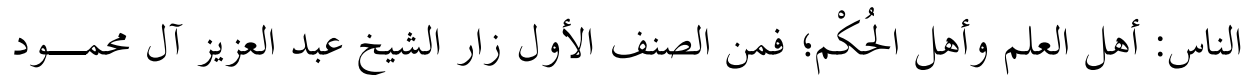

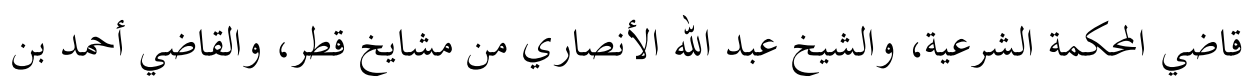

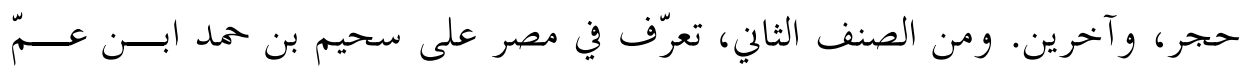

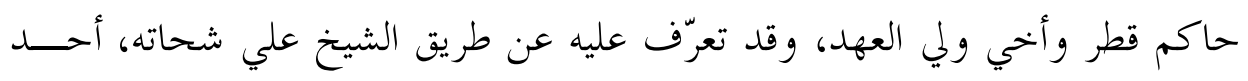

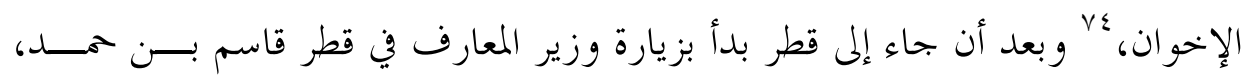

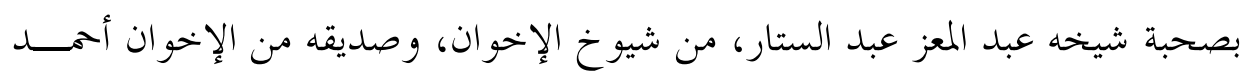

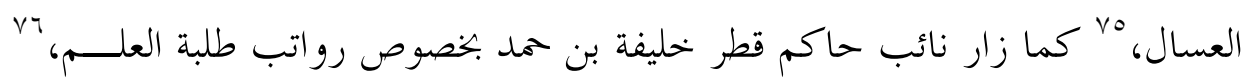

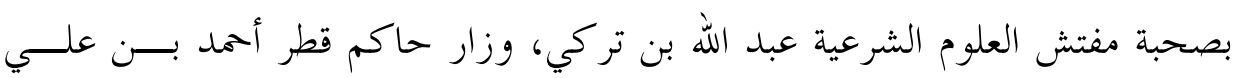

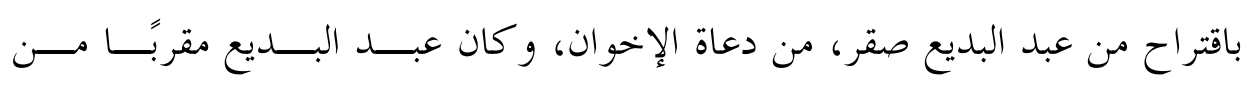
الحاكم.

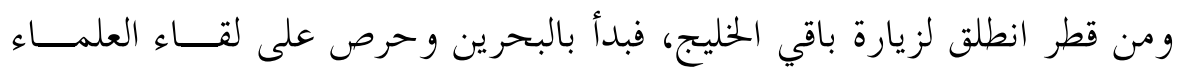

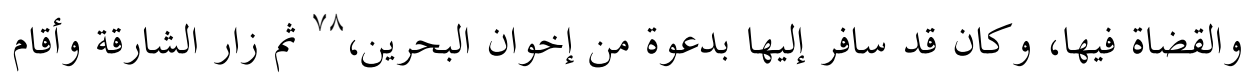

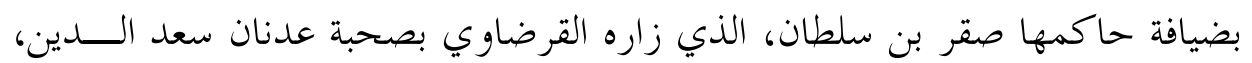

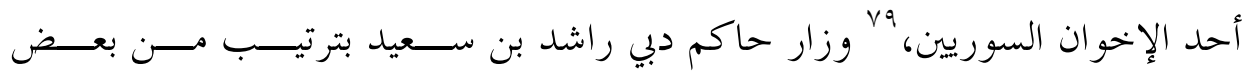

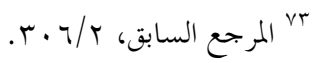

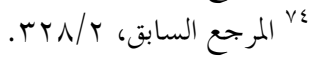

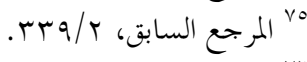

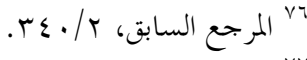

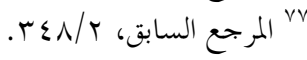

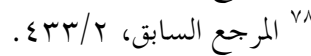

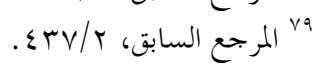


الإخوان، •^ كما زار حاكم عجمان، وتعرف على بعض الشخصيات العلمية والدينية

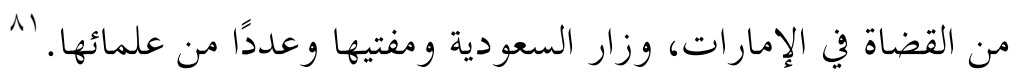

لكن مع إبراز هذا الدور الجموهري والمركزي لفكر الإخوان المسلمين، في تكــوّن

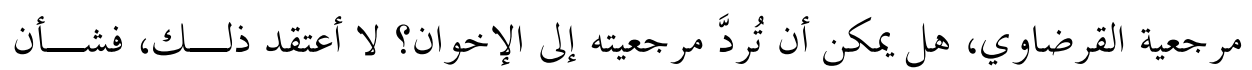

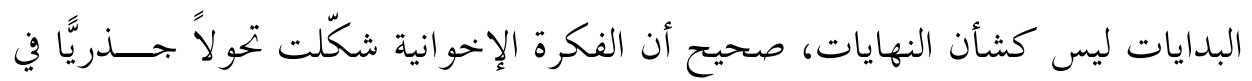

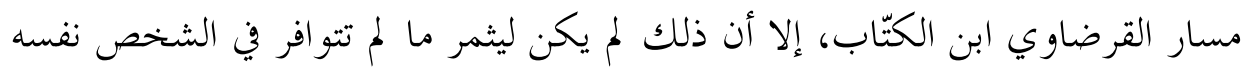

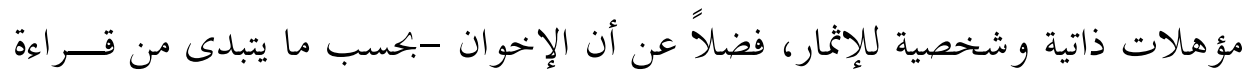

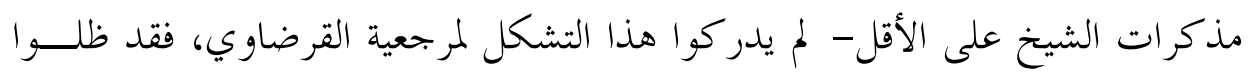

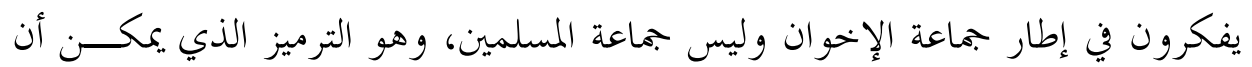
تحمله فكرة عرض منصب المرشد العام عليه في المرتين. و كذلك يتبدى هذا من خحلال

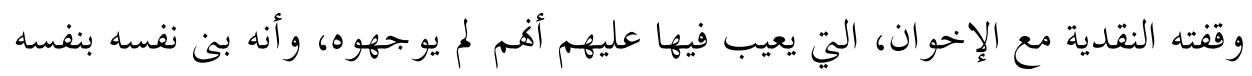

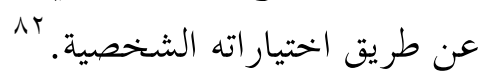

لقد أدى إرساء فكرة "النظام الشامل" بكل رو افدها ورموزها، إلى ما سمي لاحقًا باسم "الصحوة الإسلامية" في السبعينات من القرن العشرين، بعد أن سيطرت الفكرة

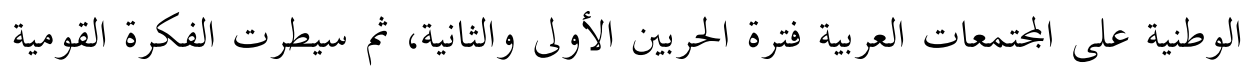

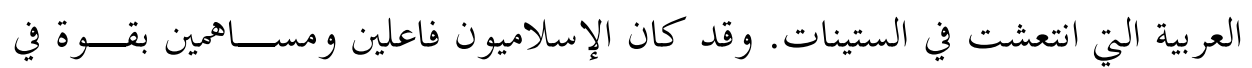

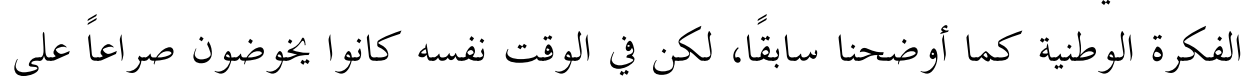

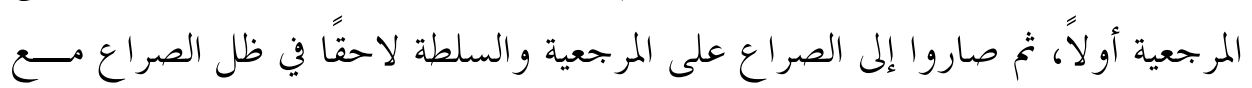

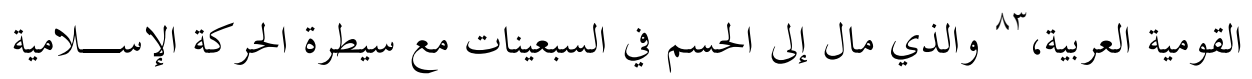

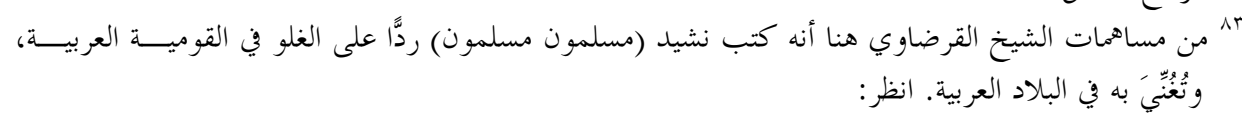

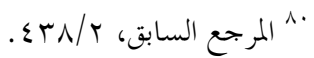

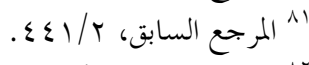

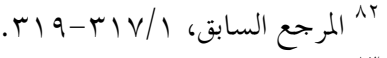

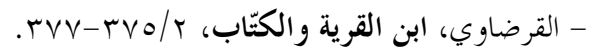




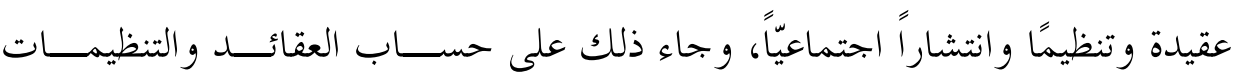

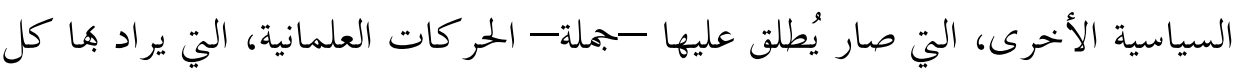

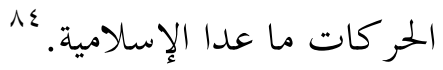

ومهما قيل من تفسيرات "للصحوة الإسلامية"، فإن الإسلام شكّل إمكانية شرعية و تعبوية وتنظيمية كبيرة، خاصة مع وجود نخبة مفكرة حوّلته إلى "مذهبيــة سياســية

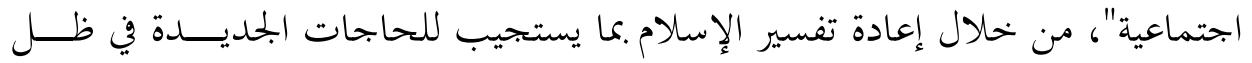

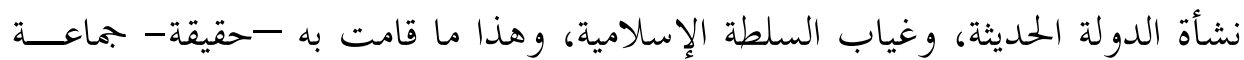

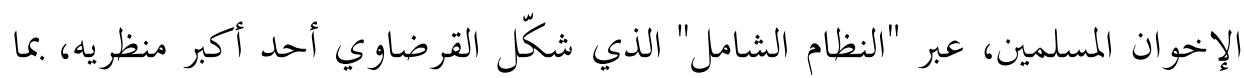
يمتلكه من رصيد تراتي وفقهي كبيرين.

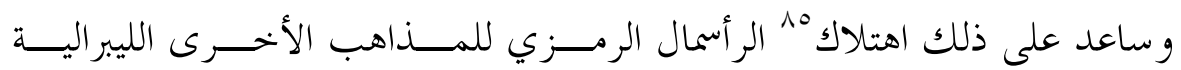
والاشتراكية، ذات المنشأ الغربي. وهنا تحديدًا يمكن تفسير التوجهات التي نشــأت في تهري السبعينات لإعادة قراءة التراث الإسلامي، و المشاريع التي قام بها علمانيون ويساريون. وما كان لهذا الانتشار الكبير للفكرة الإسلامية الجلديدة أن يمسرّر دون صــراعات جديدة، وهنا يحضر الصراع مع العلمانيين الذين يقيمون تعارضًا بين العلمانية والدين،

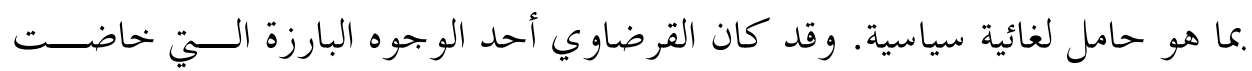
مناظرات في هذا الجمال، فقد خاض -مع شيخه الغزالي- مناظرةً مشهودة في الثمانينات

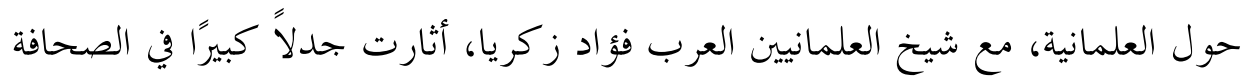

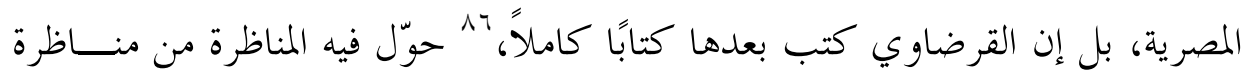

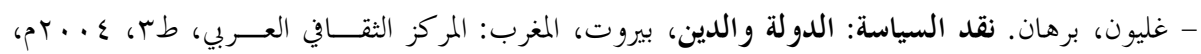
صTIV-Y

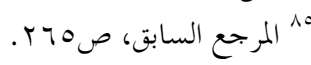

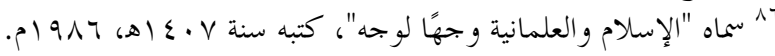


مسموعة إلى مناظرة مكتوبة استمرّ تأثيرها حتى الآن. ^و وقد شكّل القرضاوي أحســـ

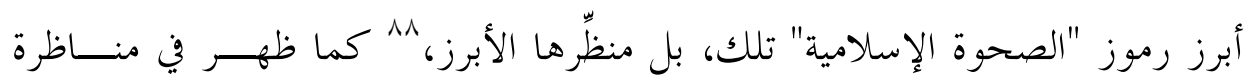

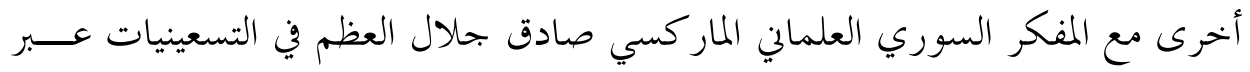

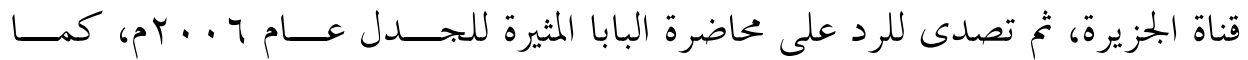

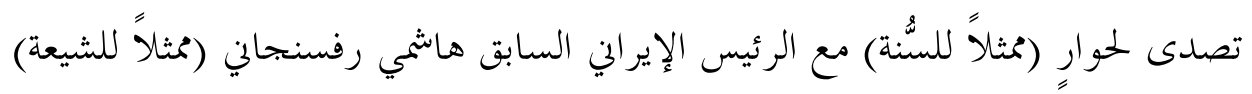

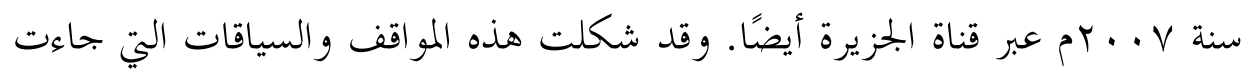

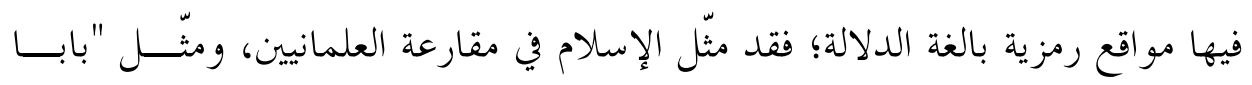
المسلمين" في مقارعة مقولات باتبا الفاتيكان.

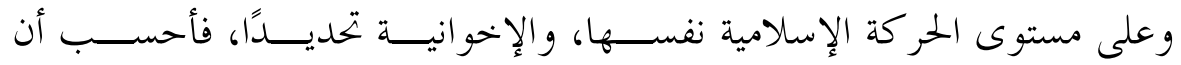

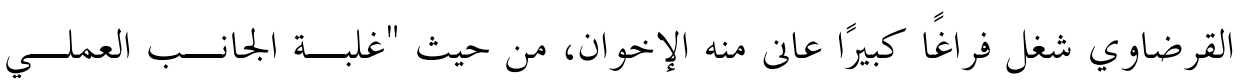

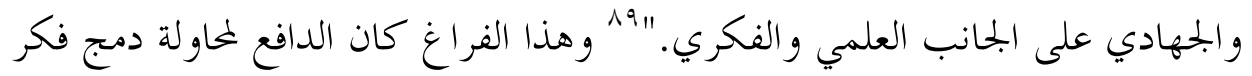

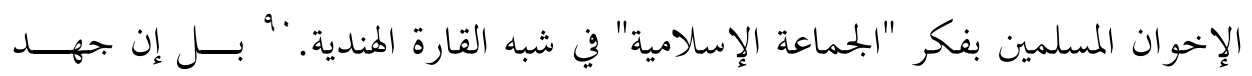

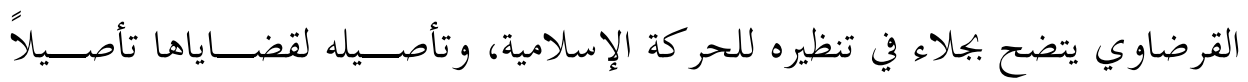

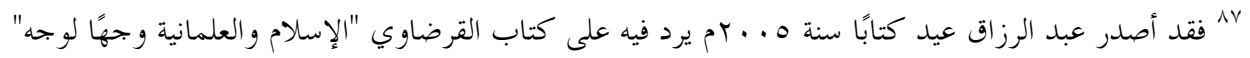

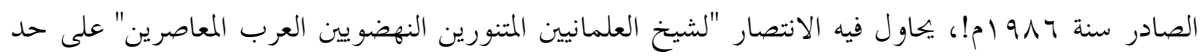

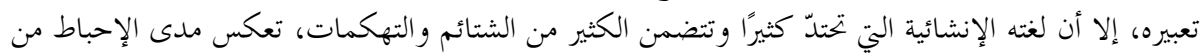

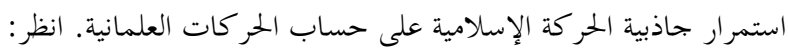

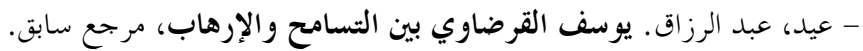

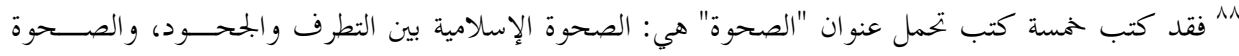

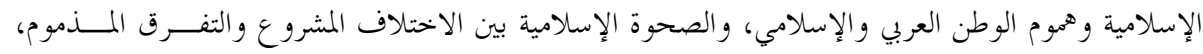

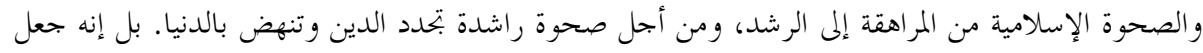

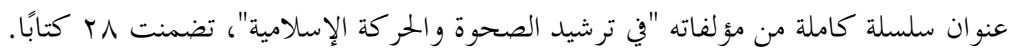

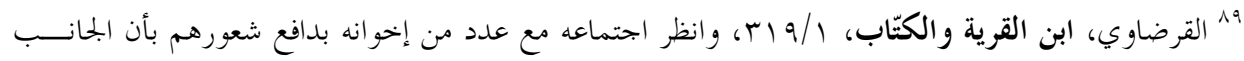

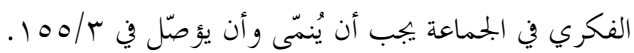
" انظر:

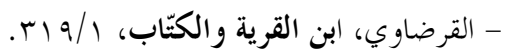
- حيدر، خليل علي. الحركات الإسلامية في الدول البالئ العربية، الإمارات: مركز الإمارات للدراسات والبحوث

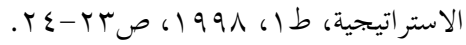




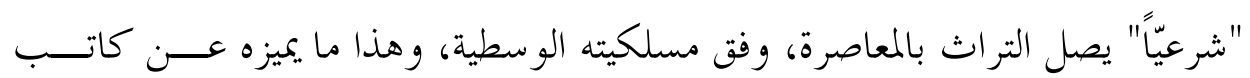

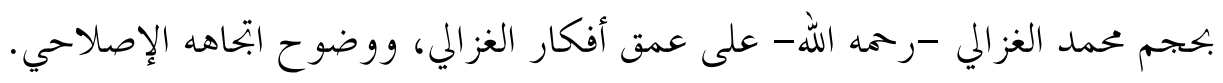

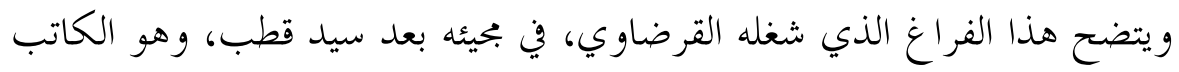

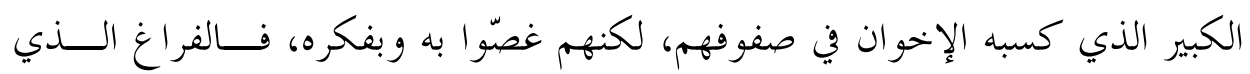

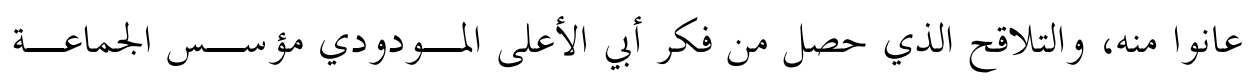

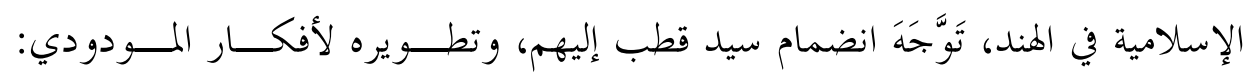

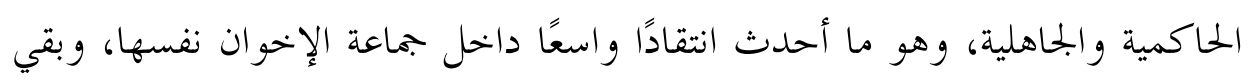

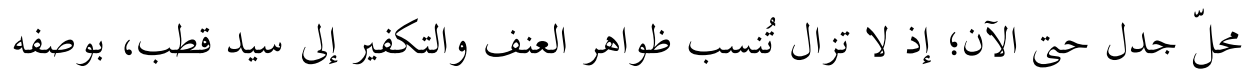

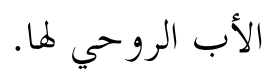

وفي الو اقع، ساهمت جهود القرضاوي في رأب الصدع الذي أحدثثه أفكار ســيد

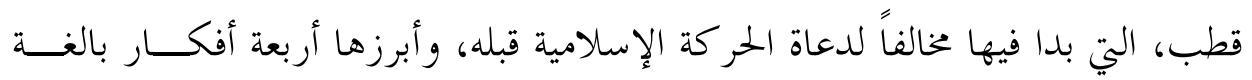

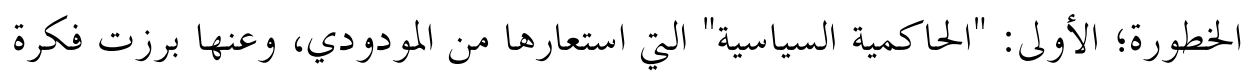

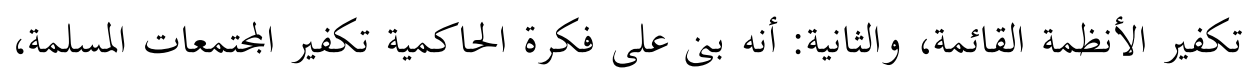

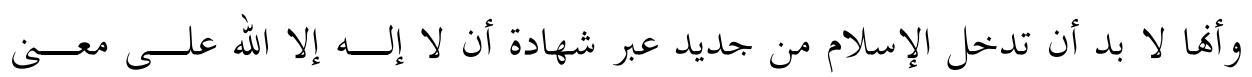

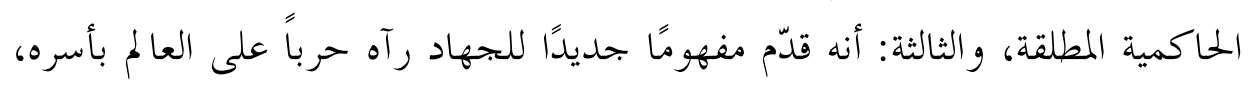

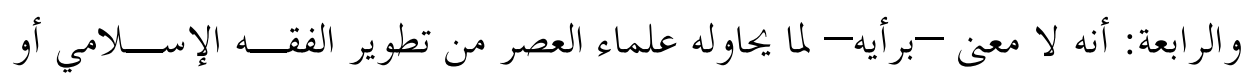

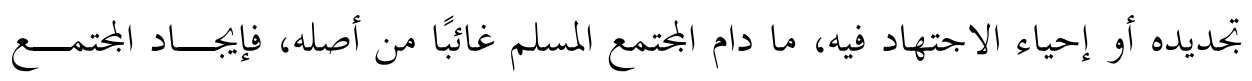
المسلم يسبق الاجتهاد له لحل مشكلاته.

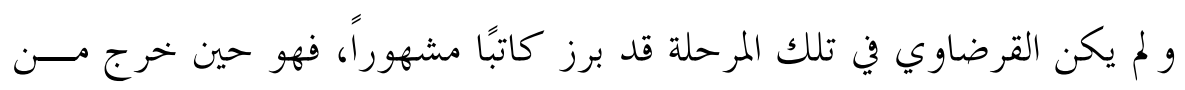

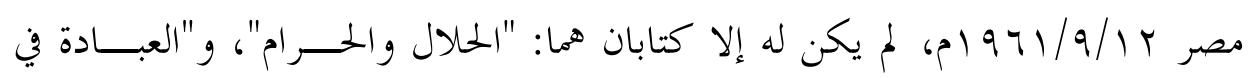

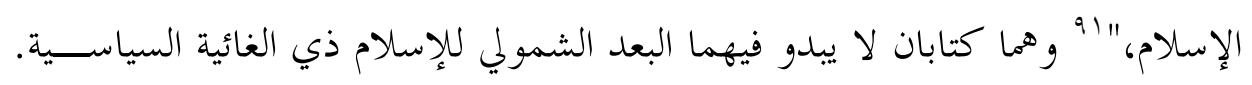




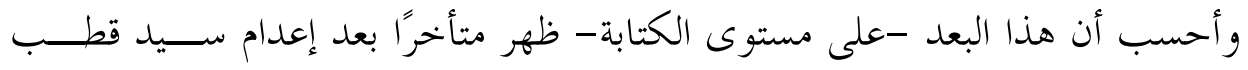

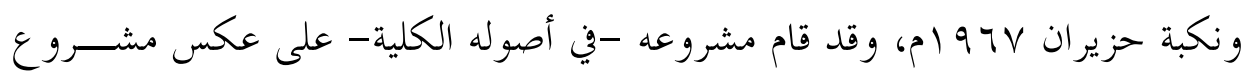

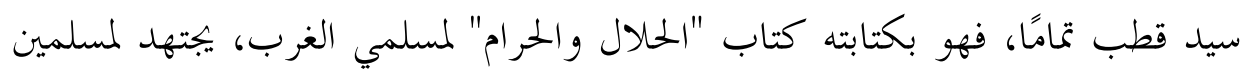

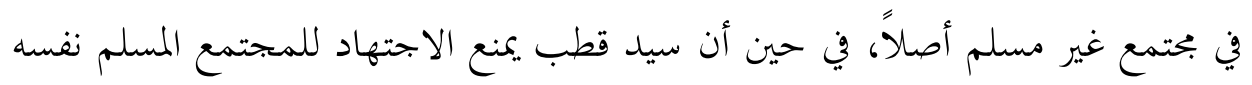

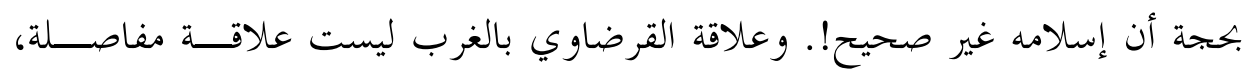

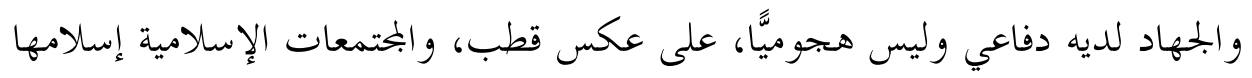

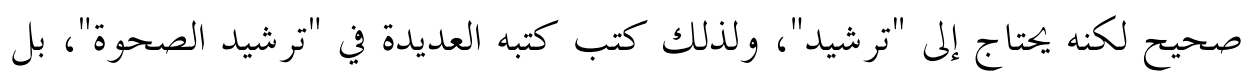

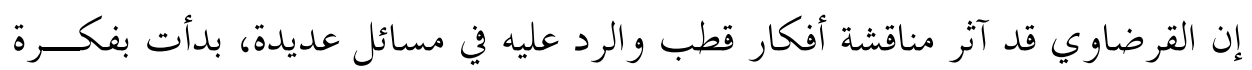

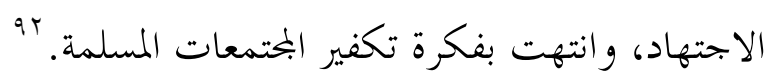

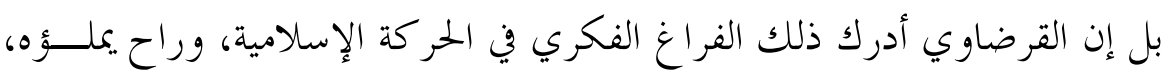

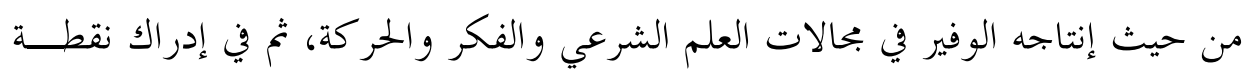

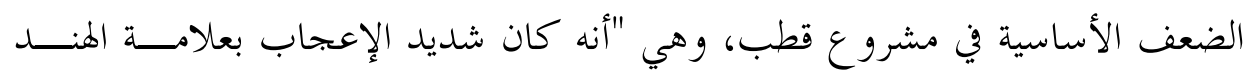

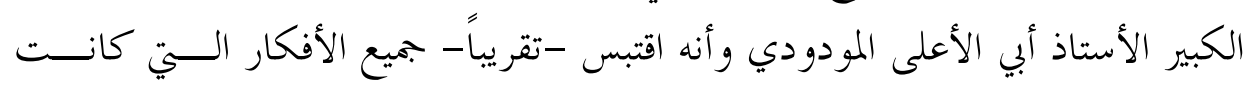

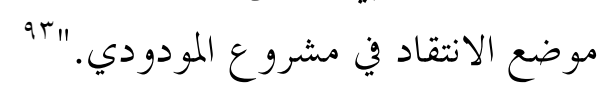

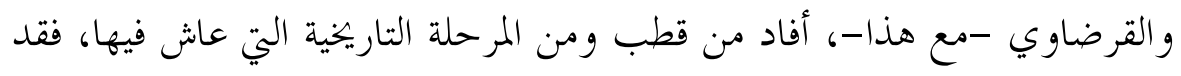

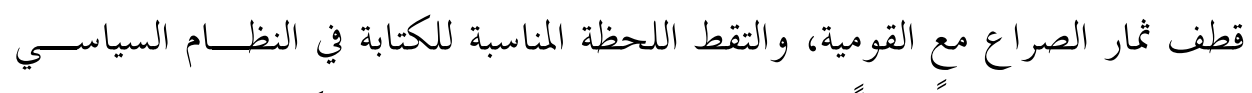

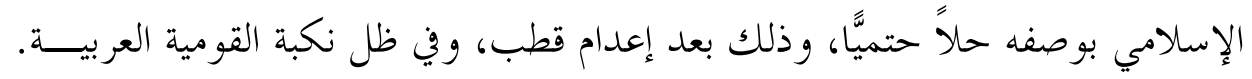

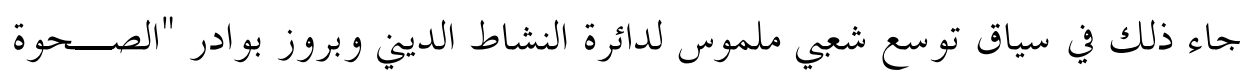

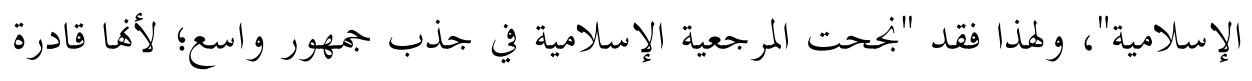

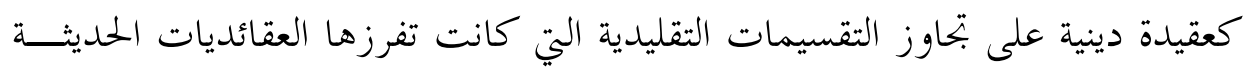

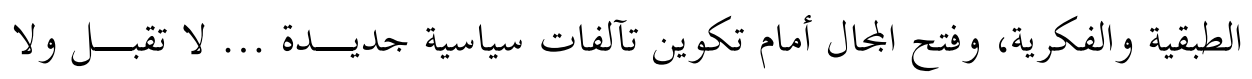

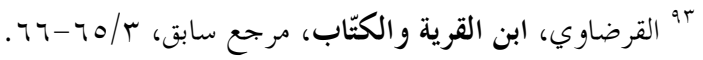


تقصي إلا على أساس معيار واحد: إعلان الانتماء للإسلام، و الأخذ به شعارًا سياسيًّا

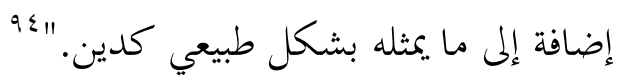

هذا المعنى، يمكن فهم وسطية القرضاوي وإضافته التي قدمها للحر كة الإســالامية،

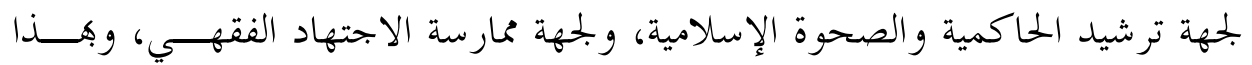
المعنى شكّل رافدًا كبيرًا لإزالة الغلو و التطرف الذي طرأ على الحالة الإسلامية، بفضل

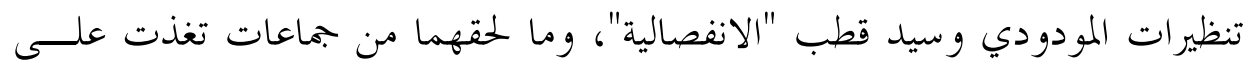

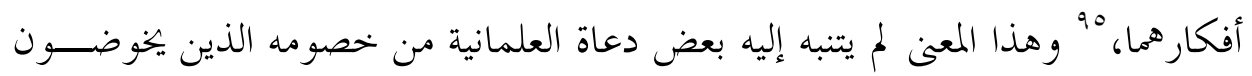
معارك شخصية وأيديولوجية معه ومع فكره، دون إدراك للحالة الفكرية والاجتماعية العامة التي سادت منذ السبعينات وحتى الآن، و كيف أنه شكّل صمَّام أمان حال دون توسع مزاج التشدد وأفكاره، فبقي مقتصراً على جماعات وفئات معزولة هنا وهناك. وبهذا فتد جاء مشروع القرضاوي ضد مشرو ع قطب الذي تعاطى مع الإســلام

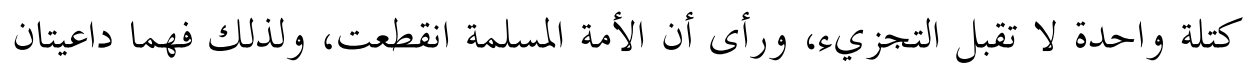
متفاوتان: الداعية المناضل، و الداعية الفقيه.

\section{ثالثاً: مكوّنات المرجعية}

إن الحديث عن فكرة المرجعية في العالم السُّيّي محفوف بإشكال كبير؛ إذ المرجعية

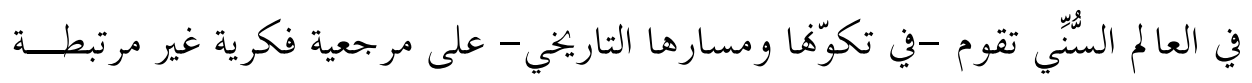
بأشخاص كما قدّمنا، وسوف نغتنار من مكونات هذه المرجعية ثلاثة عناصر هي:

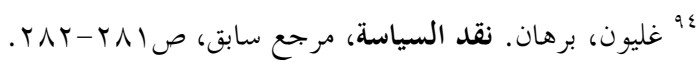

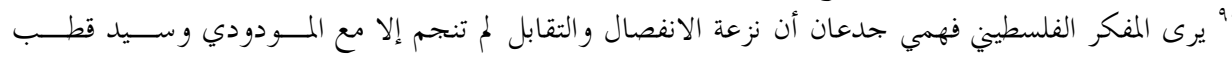

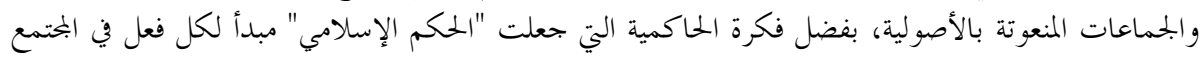




\section{ا ـ مركزية الفقه/الشريعة:}

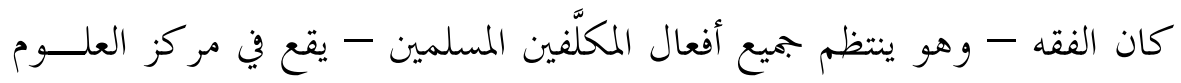

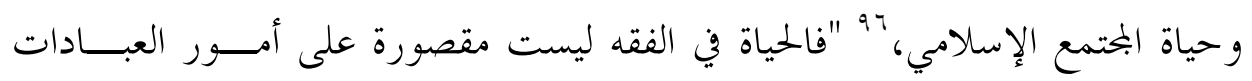

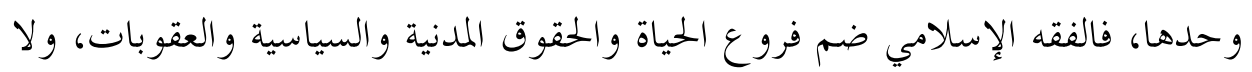

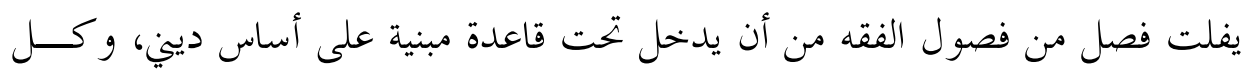

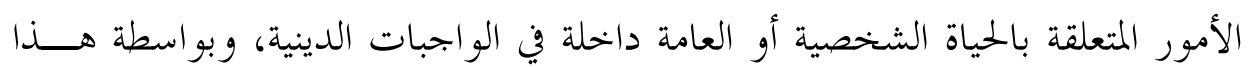

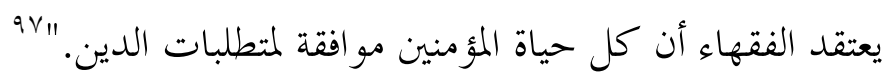

وتتلخص مهام الفقه في ثلاث: الأولى: التطبيق في المحاكم والقضاء، والثانية: أنســ

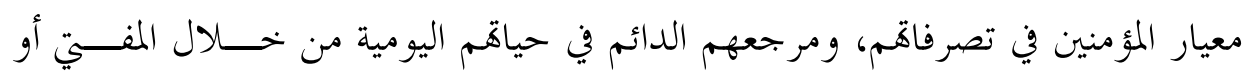

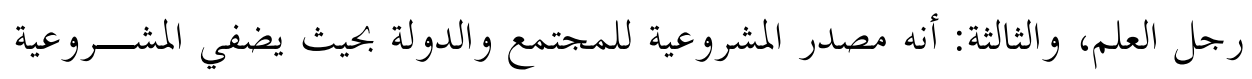

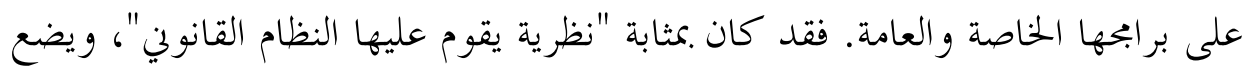

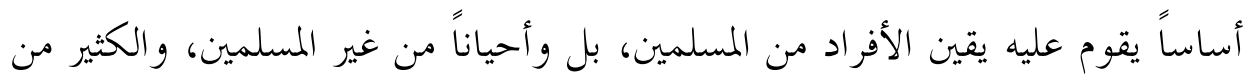

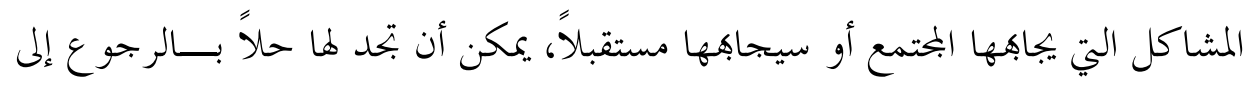

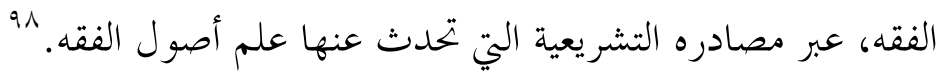

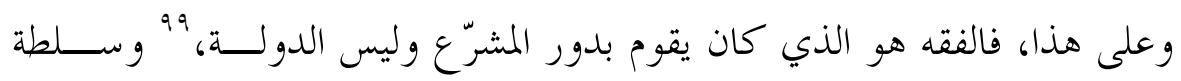

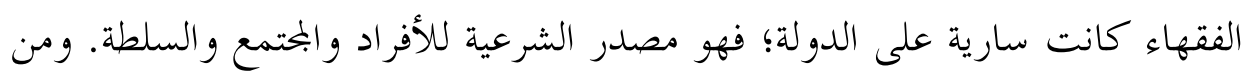

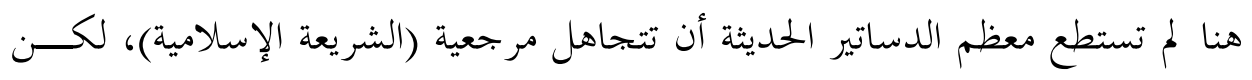

$$
\text { 99 انظر حول مر كزية الفقه: }
$$

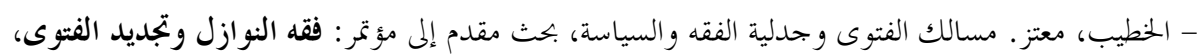

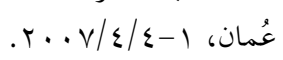

97 تسيهر، جولد، العقيدة واءلانو، الشريعة في الإسلام، (الترجمة العربية) القاهرة، بغداد: دار الكتب الحديثـة، مكتبــة

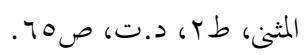

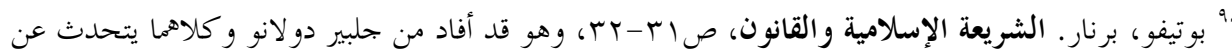

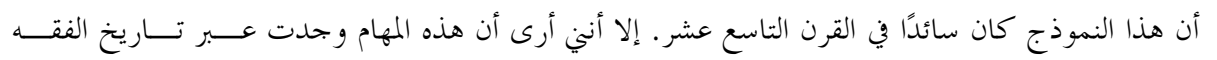

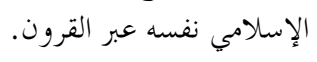

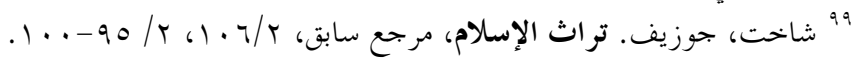


بقي ذلك على نطاق ضيق وغير فاعل في أغلب الأحيان، وهذا مــــ أدى إلى انتشــار

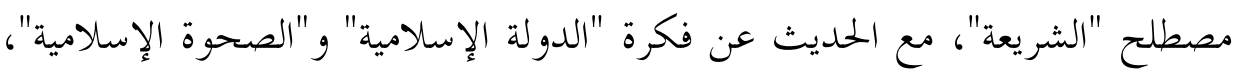

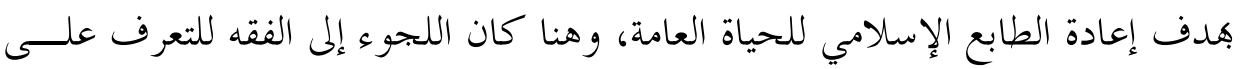
حلول مناسبة لأسئلة الناس و العصر.

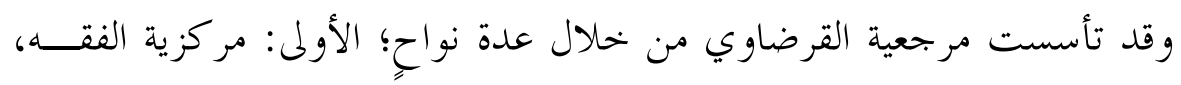

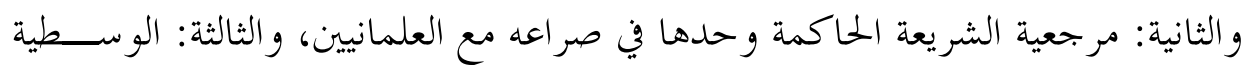

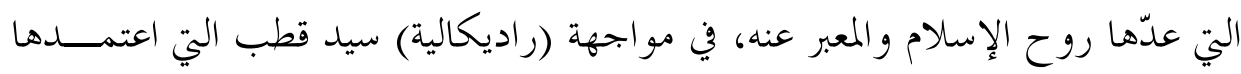

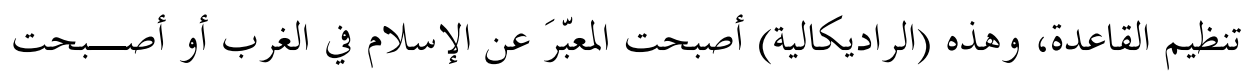
المعنيّ بوصف: الإسلاميين.

بدا متزع القرضاوي الفقهي مبكرًا، وهو ما لاحظه عليه شيخه البهي الحولي من

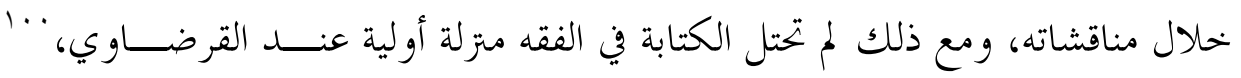

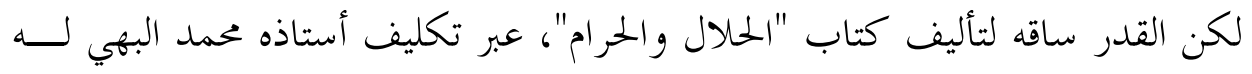

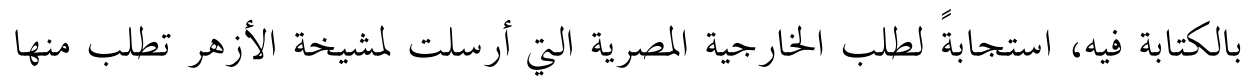

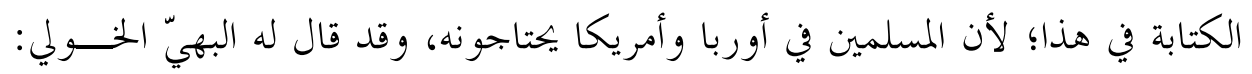

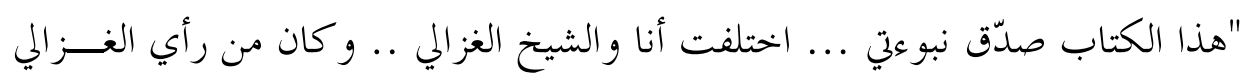

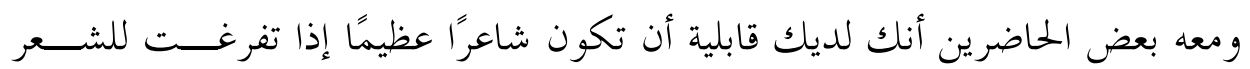

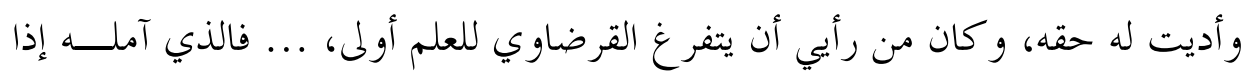

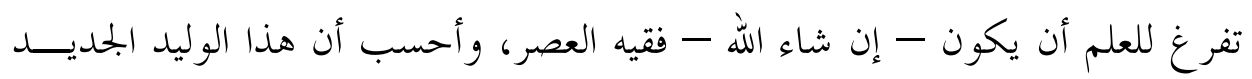

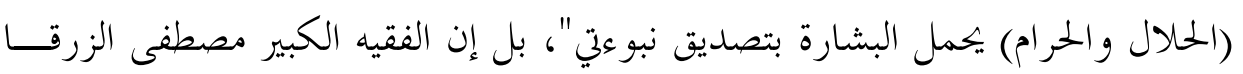

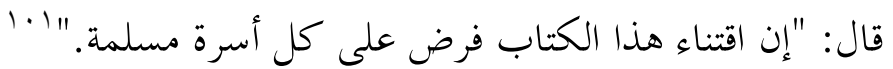


والاحتفاء الكبير الذي قوبل به الكتاب من رموز الفكر و الفقه، وخحاصة منظــــي

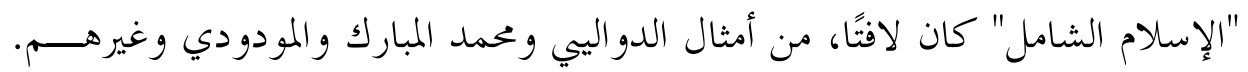

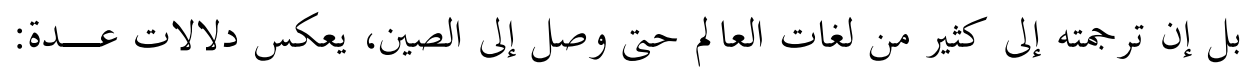

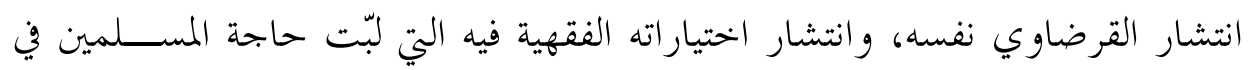

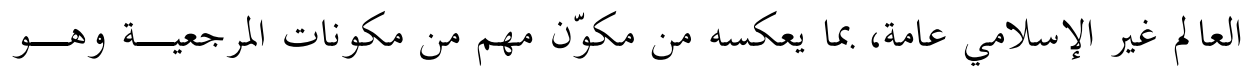

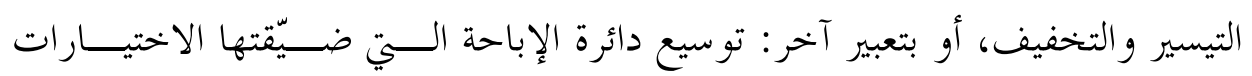

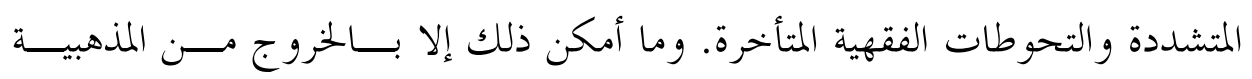

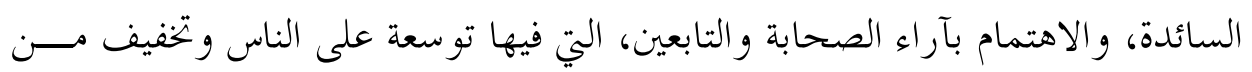
المقيِّدات. r.

كما أن جهد القرضاوي الفقهي يمكن أن يندرج ضمن توجه فقهي عام، ســـاد

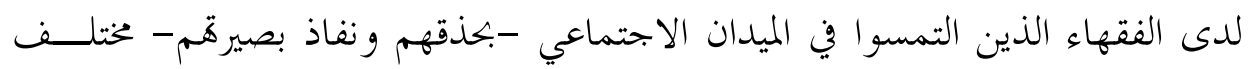

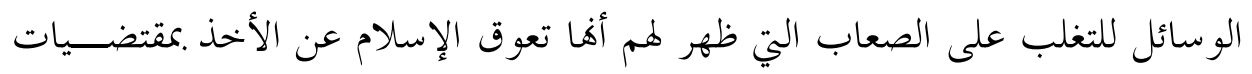

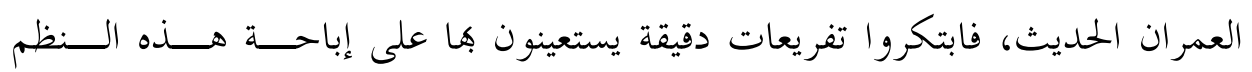

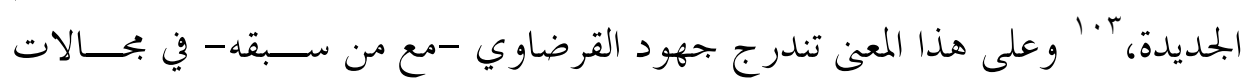

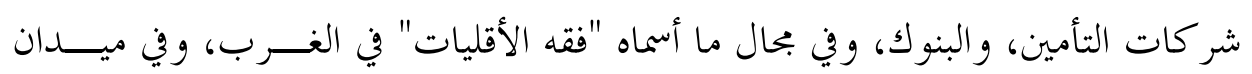
المسائل السياسية الكبرى كالانتخابات و الدستور و الديمقر اطية وغيرها.

وهذذه الطريقة استطاعت الحياة الإسلامية أن تأخذ عن المدنية الغربية ما يلائمهـــا

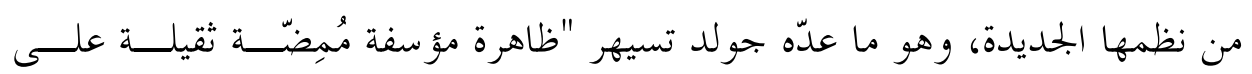
النفس؛ إذ إن الأنظمة النافعة ذات القيمة العملية والمصلحة الحيوية، لا يُستطاع تنفيذها

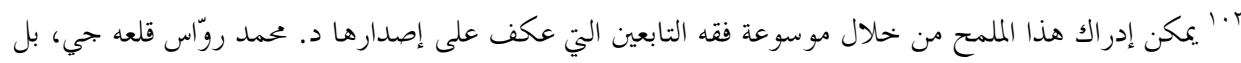

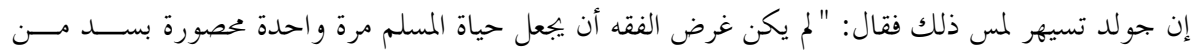

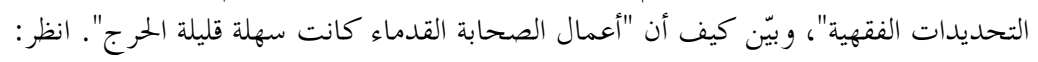

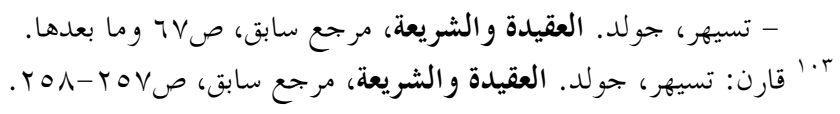




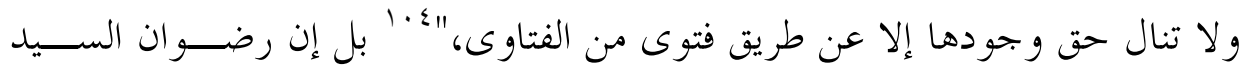

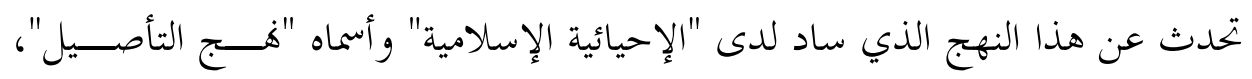

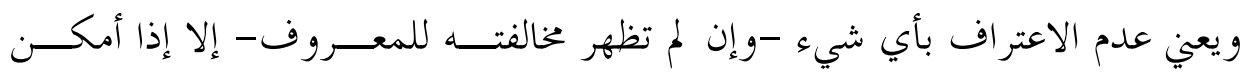

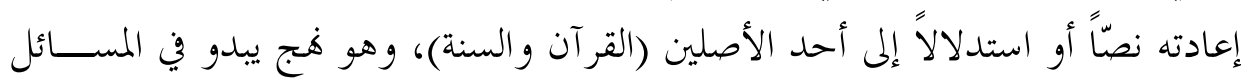

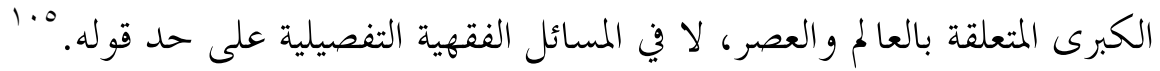

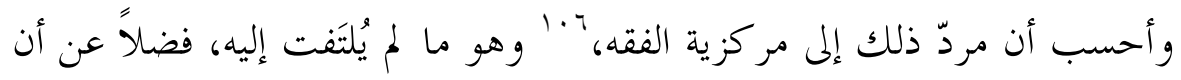

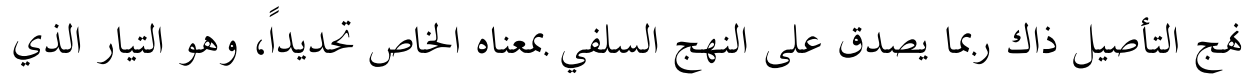

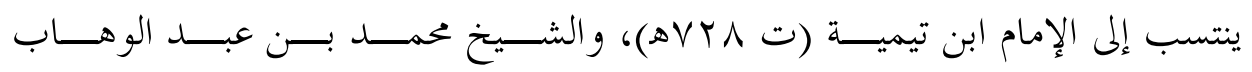

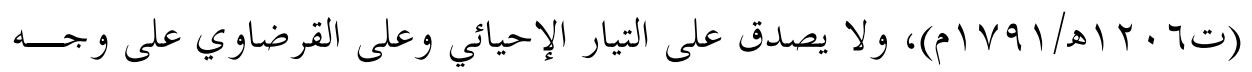
الخصوص.

كما أن الأنثربولوجي المعروف طلال أسد وهو يعيد التفكير في مفهوم "التقليـــ"

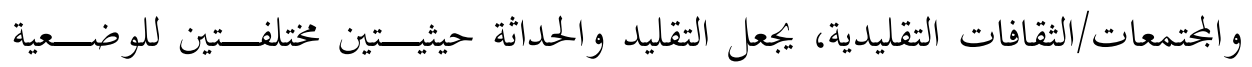

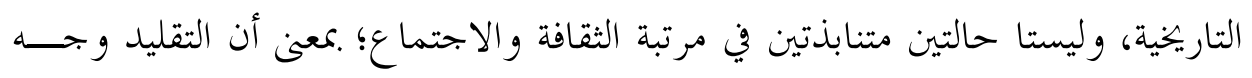

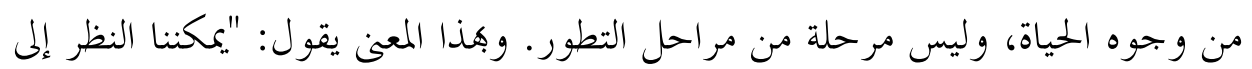

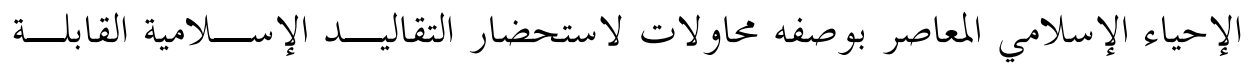

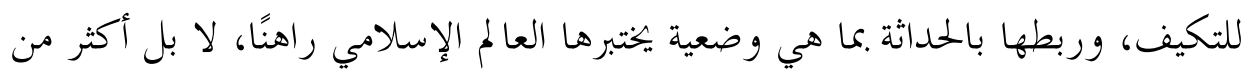

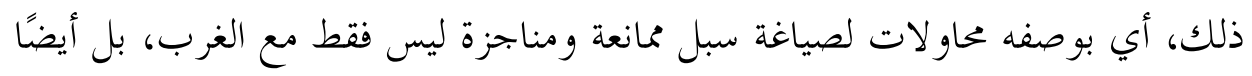

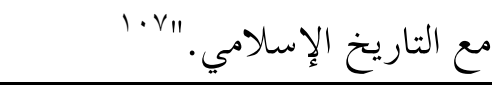

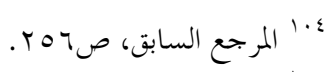

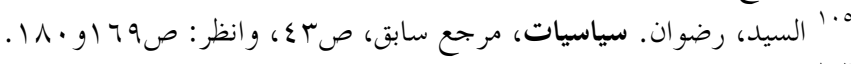

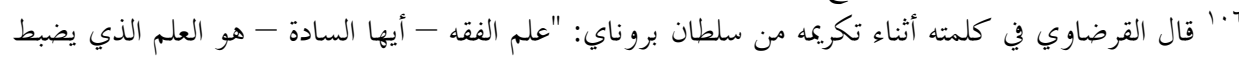

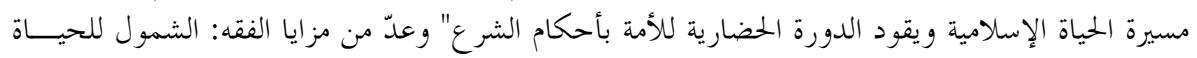

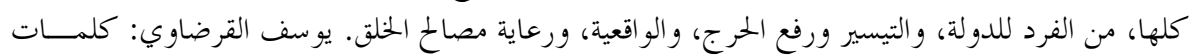

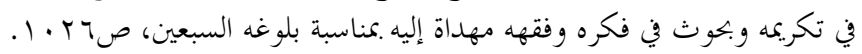

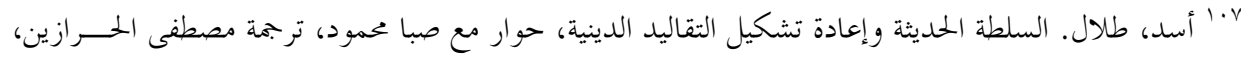

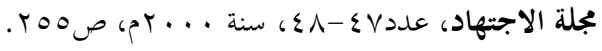




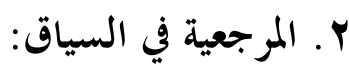

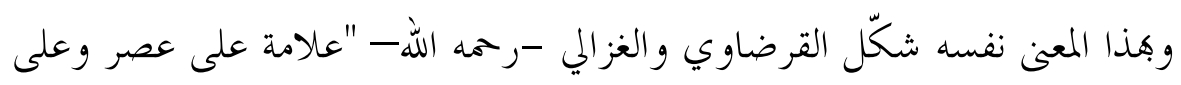

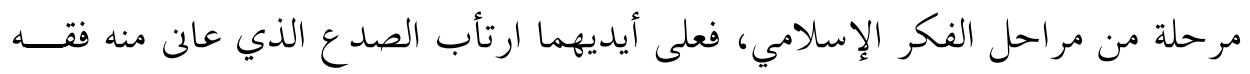

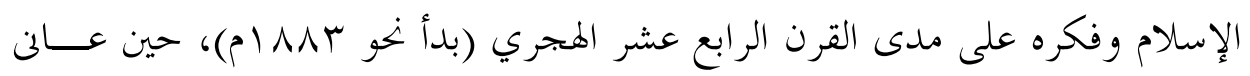

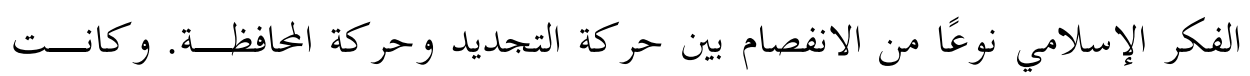

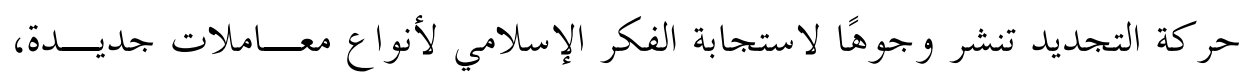

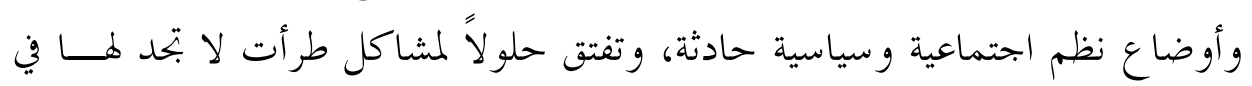

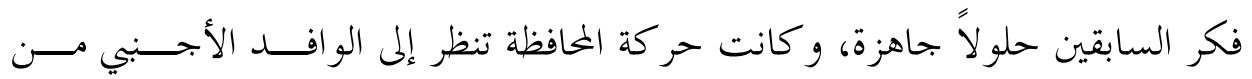

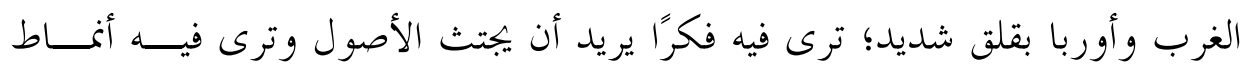

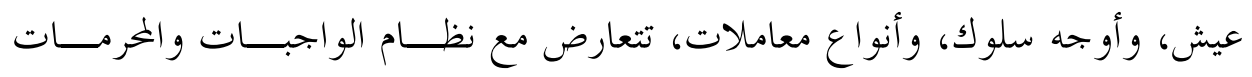

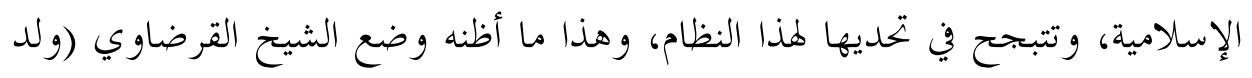

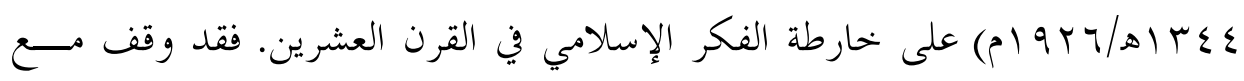

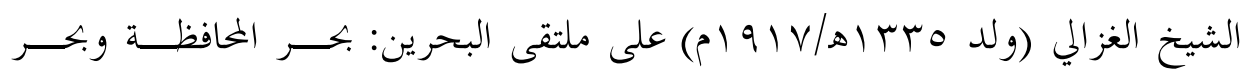

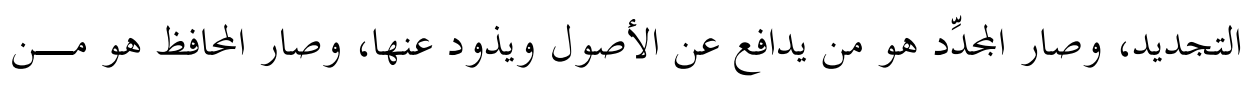

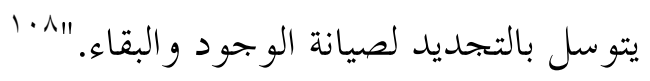

والجدال بين تياري المحافظة والتجديد كان يدور على ساحة الشـــيعة -بمعناهــــا

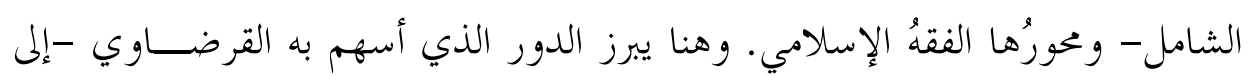

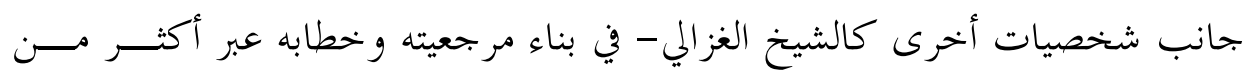

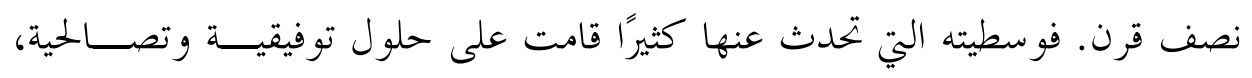

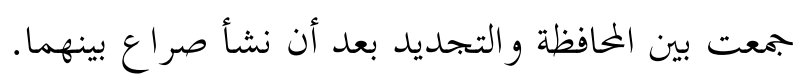

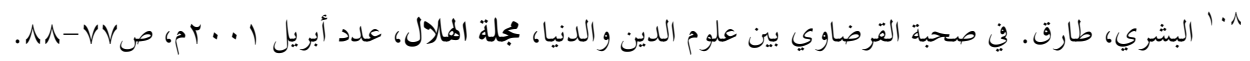


وهو في هذا استطاع أن يُشيع خطاباً معاصراً يستثمر فيه المصطلحات الحديثة في

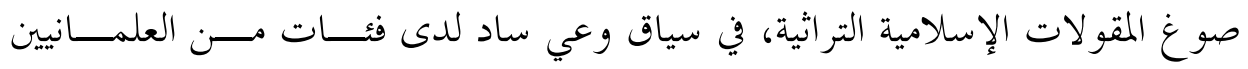

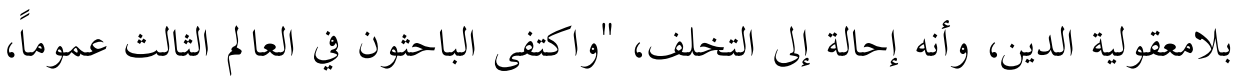

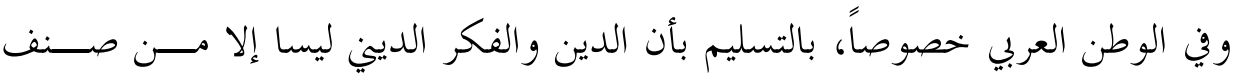

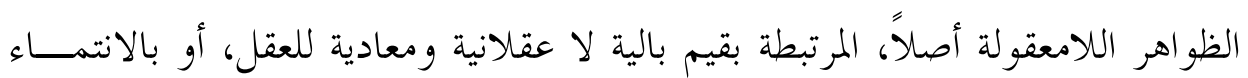

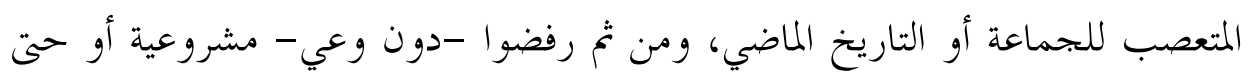
إمكانية البحث العقلاني في الدين."1"1.

ومع أن القرضاوي اتصف بالانفتاح و التواصل مع الغرب، فإن وسطيته التي توائم

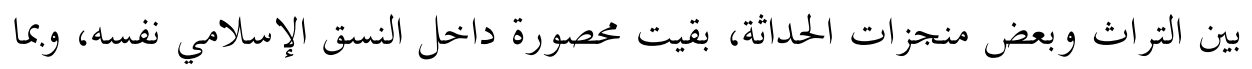

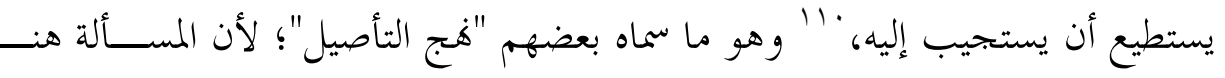

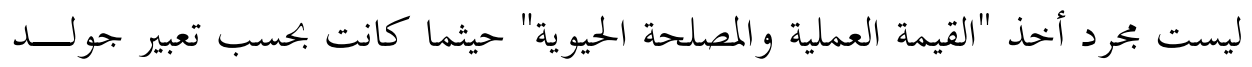

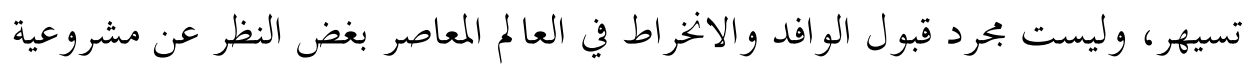

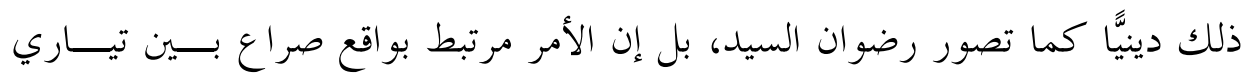

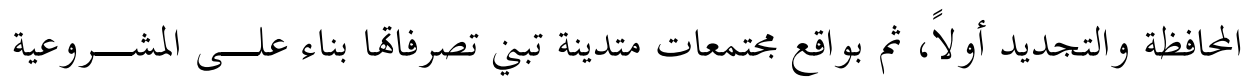

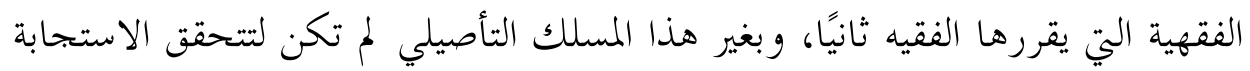
اللازمة، و لم يكن بالمقدور تكوّن المرجعية الدينية.

كما أن السياق الذي نشأ فيه ذلك الخطاب، وتمت فيه تلك الاسـتجابة، كــان

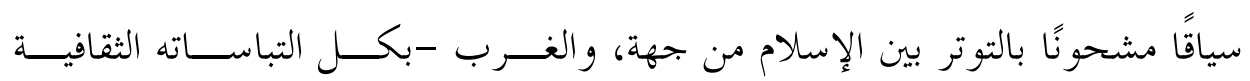

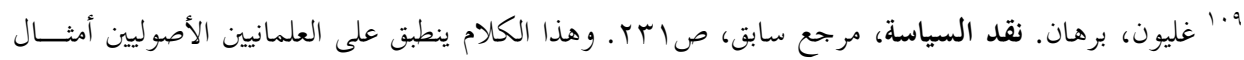

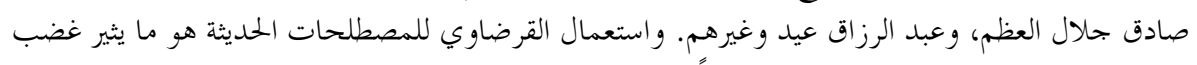
عبد الرزاق عيد مثلا في كتابه المشار إليه سابقًا.

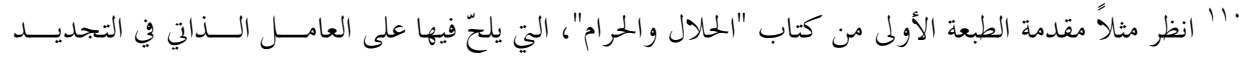

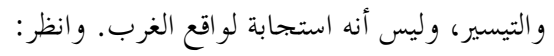

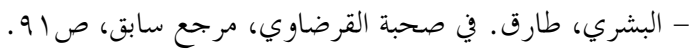


و الاستعمارية- من جهة أخرى، وهنا نشأت فكرة الحفاظ علــى الهويـــة المهـــددة،

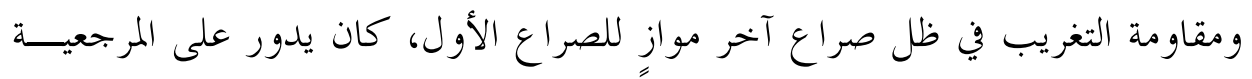

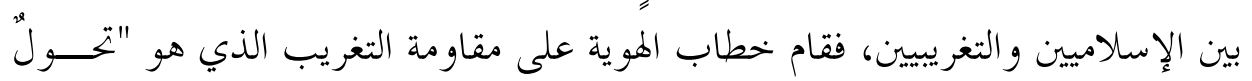
فعلي روحي -بقدر ما هو فكري- بابحاه ديانة الغرب اللأدرية"؛ إذ بحد الحداثة ديانة بديلة، '"' وخاصة مع غلبة العقلانية المفترضة واسترذال الدين. إلى ذلك فإن حرية الحركة والنشاط التي أتيحت له في قطر، أسهمت في تكـــوين

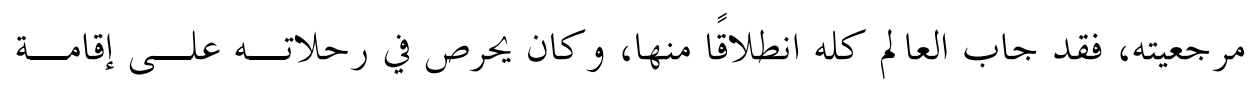

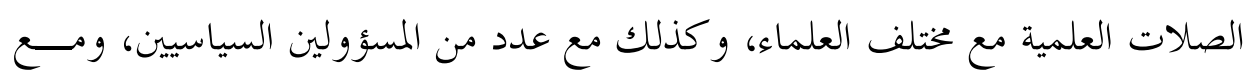

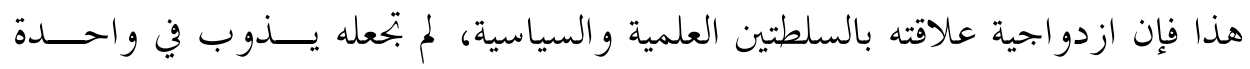
منهما، فحافظ على قدر كبير من استقلاليته، ومن هنا نبعت قوة مرجعيته من أمرين:

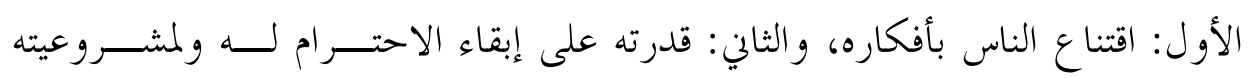

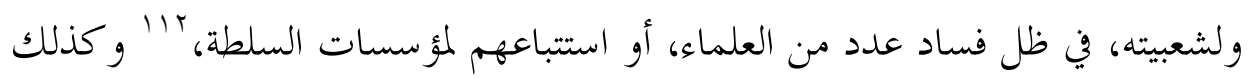

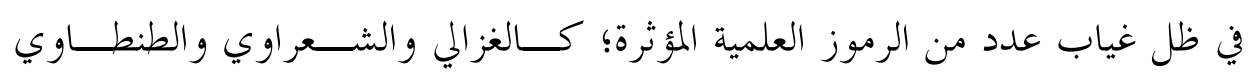
و آخرين (و كلهم كان لهم حضور إعلامي)، فضلاً عن انحسار مرجعية الأزهر لأسباب عديدة. و تبدو فكرة الاستقلالية بجلاء، من خلال تبدل موقفه من "مشيخة الأزهر"، فحين

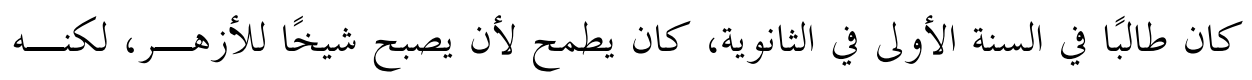

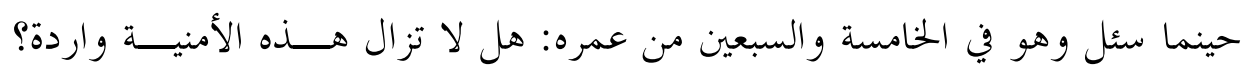

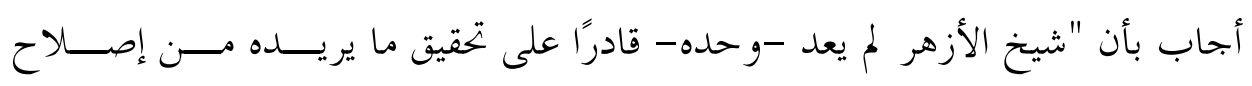

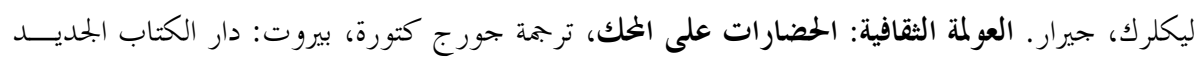

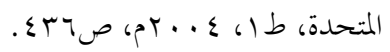

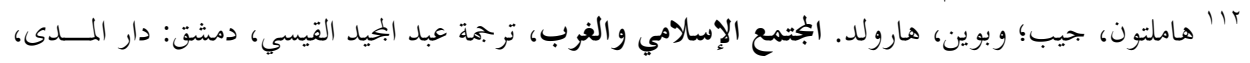
( ط ا 


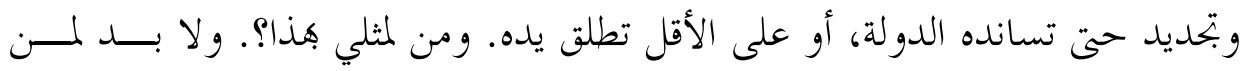

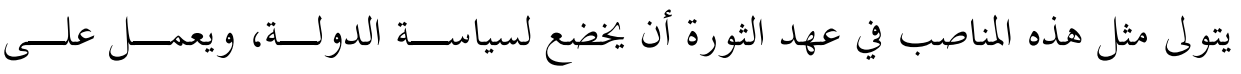
إرضائها، ويسير في ركاها: فإما أن ينطق بباطل، وإما أن يسكت عن حق، وإلا أصبح

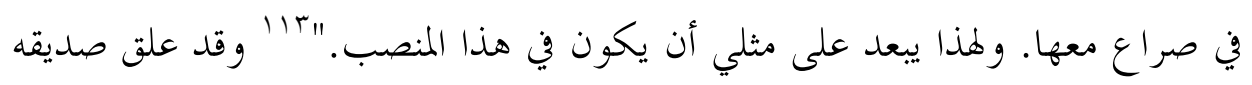

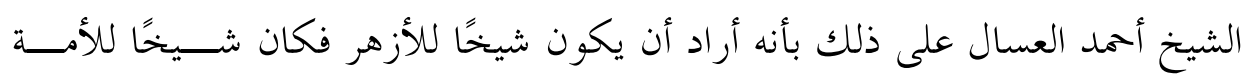

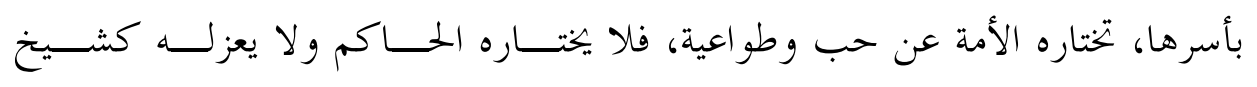

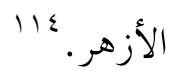

إن مثل هذه المو اقف تعكس رفضًا لفكرة "المناصب الدينية"، التي تحيل إلى ســلطة الدولة التي اختلت شرعيتها من جهة، و المتجاوزة للحدود القُطرية إلى الأمة الإسلامية

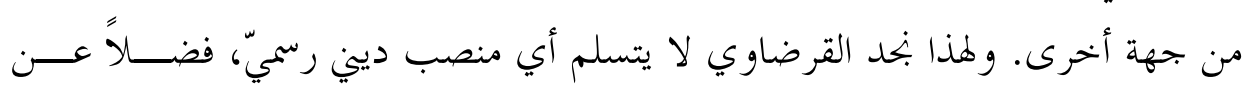

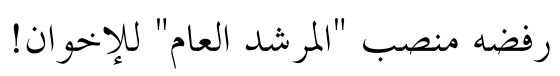

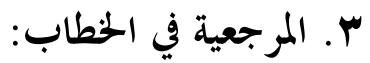

وعلى مستوى خطاب القرضاوي نفسه، فقد استطاع أن يُحدث -على المستوى

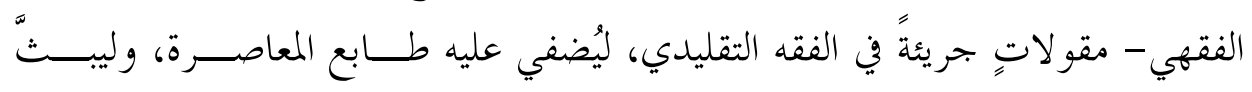

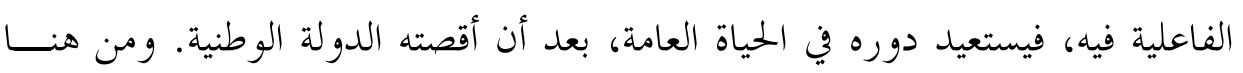

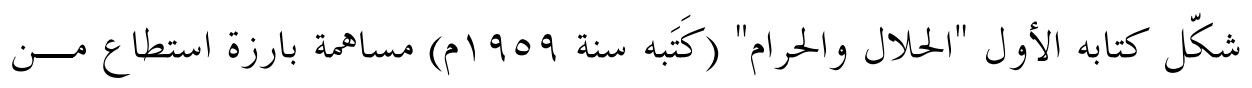

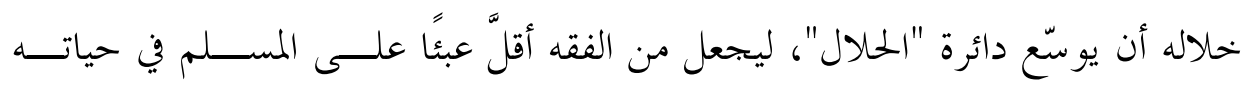

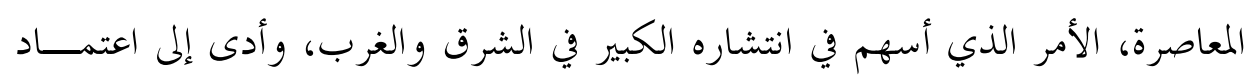
كثير من المسلمين فتاو اه. 
وفيما يخص الفقه السياسي الذي ضمر في الفقه التقليدي، فقد استطاع أن يُسهم

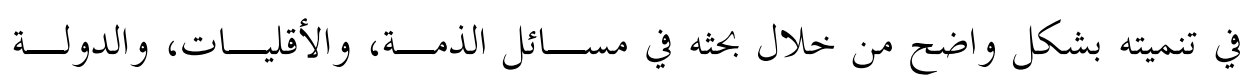

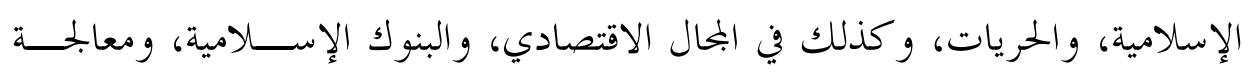

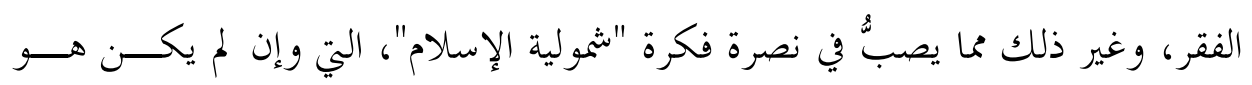

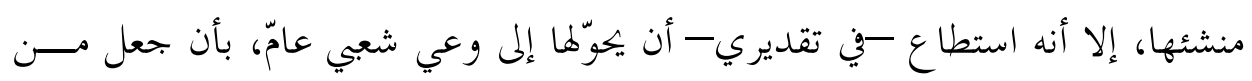
الإسلام نظام حياة لجمهور كبير من المسلمين.

وهو في سبيل ذلك كله، كان جريئًا في اقتحام مساحات سكت عنها غيره، أو لم الم

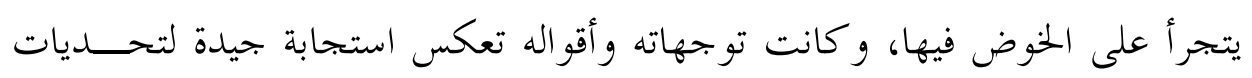

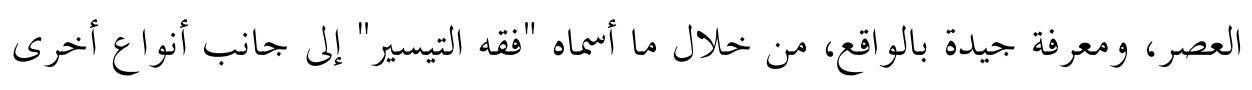

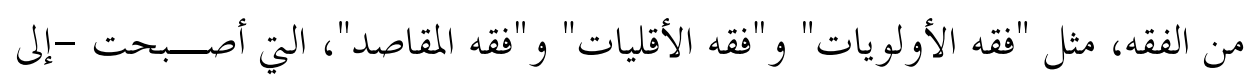

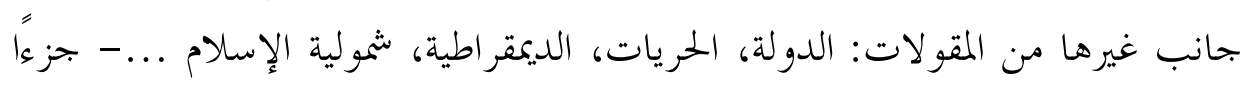

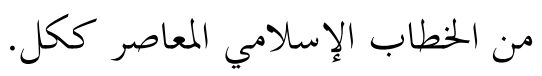

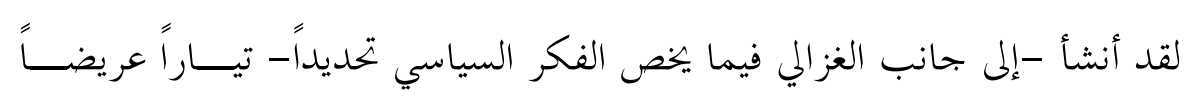

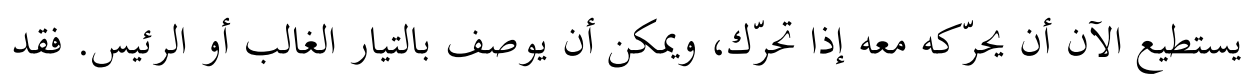

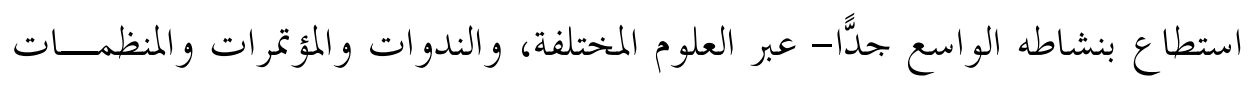

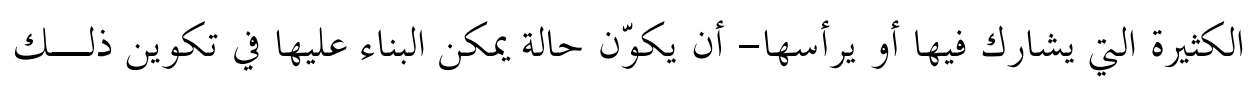

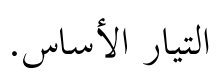
وثمة عوامل كثيرة ساهمت في تكوّن مرجعيته، لعل من أبرزهــا: موســـوعيته في

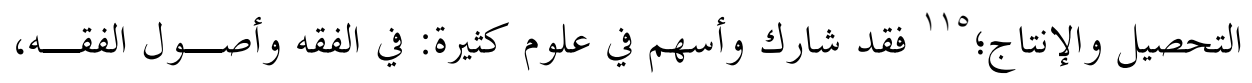

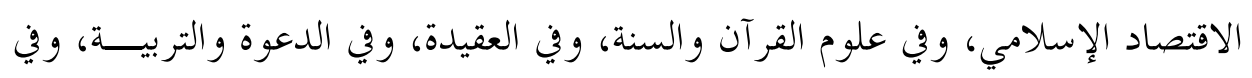
"1"1 وهذا الميل وُجد لديه قديًُا، وكان أحد أسباب اختياره الالتحاق بكلية أصول الدين التي تدرّس علوم النقـلـ

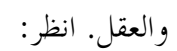
- القرضاوي، ابن القرية والكتّاب، مرجع سابق، ص7 ــ ـ. 


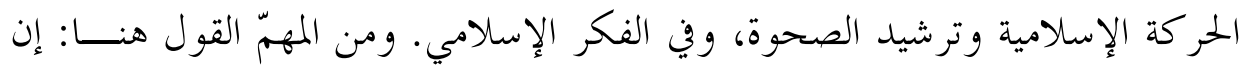

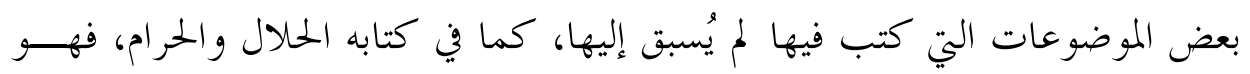

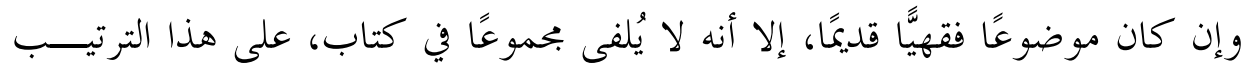

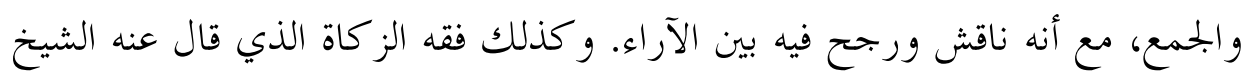

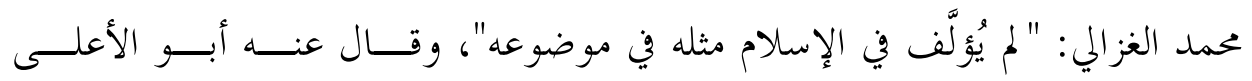

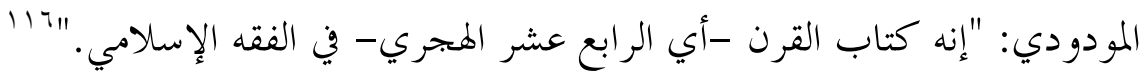
ومن مكوّنات مرجعيته سهولة خطابه؛ فقد استطاع أن يقرّب الكثير من الأفكار

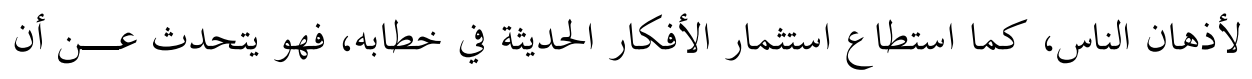

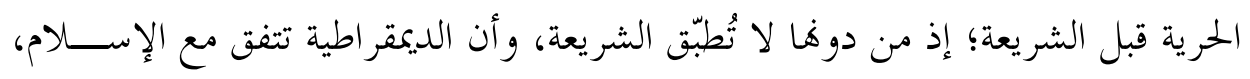

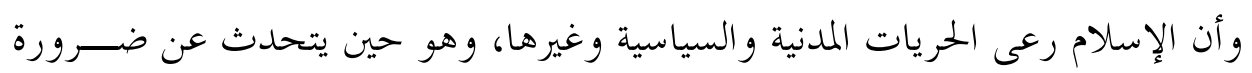

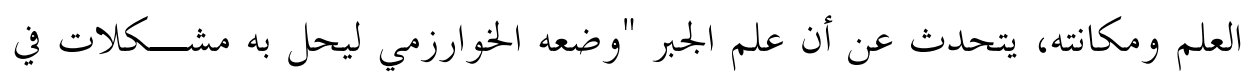

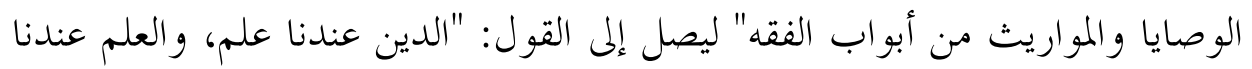

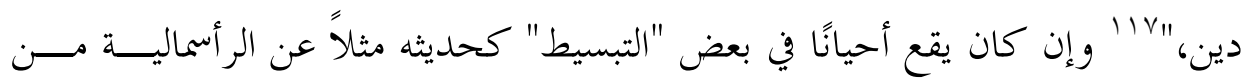

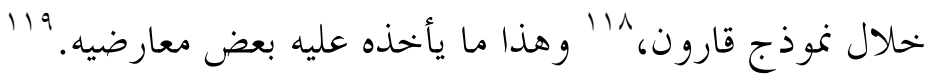

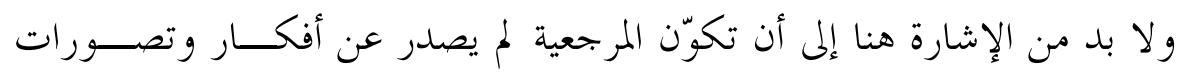

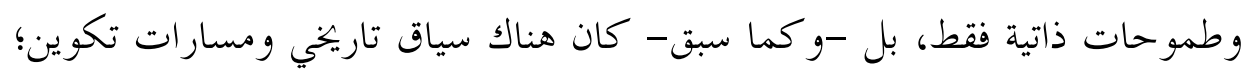

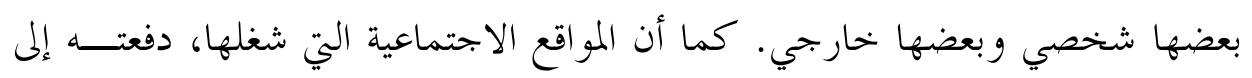
فكرة المر جعية، وساهمت في تكوينها.

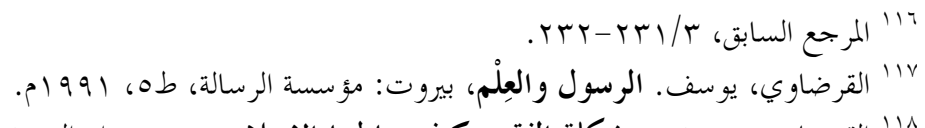

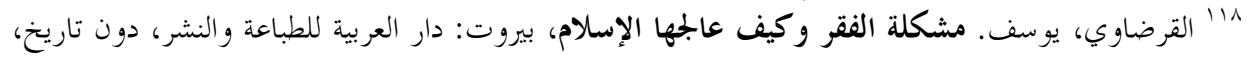




\section{رابعاً: القرضاوي: آفاق الدَّور وحدوده}

وظيفة العلماء هي الحفاظ على "الأمة" هيئة متحدة في عقيــــها، متماســـكة في

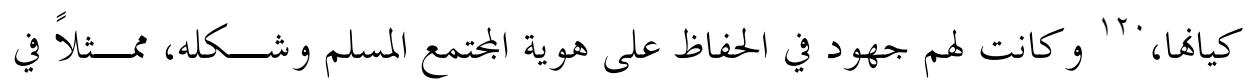

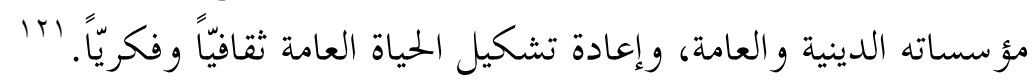

هذا الدور التاريخي للعلماء، النظري و العملي معًا، أمكن للقرضاوي أن يضـــطلع به عبر مسيرته العلمية والدعوية، فقد كان يحرص على المشاركة في النشاط الاجتماعي

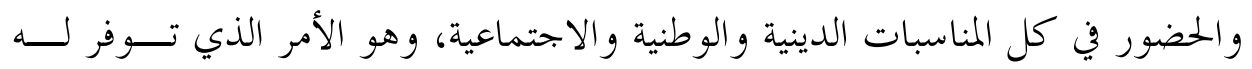

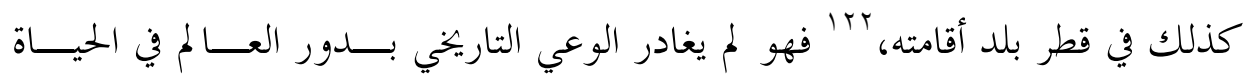

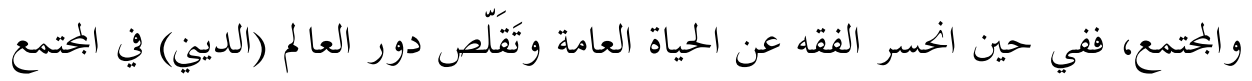

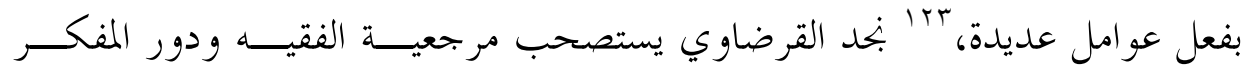

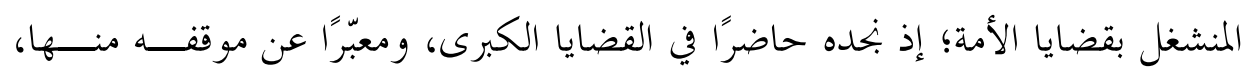
و ومُعبًِّا الجماهير لأجل ذلك ذلك.

وهذا الدور المركب الجامع بين الفقه والفكر، والمستصحب للدور الشامل، يعود

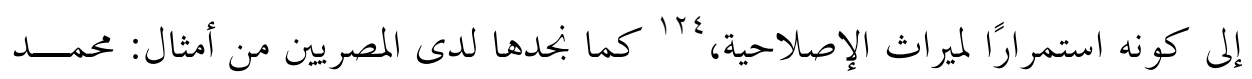

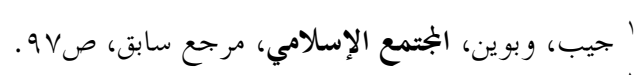

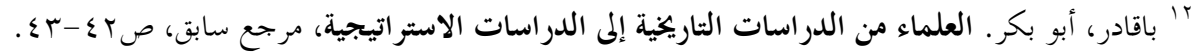

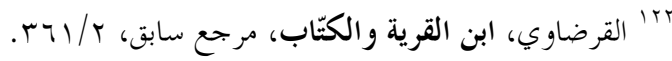

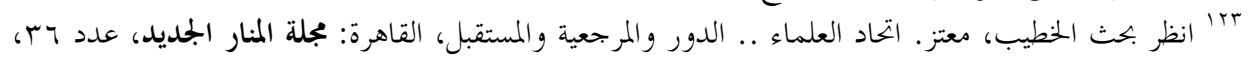

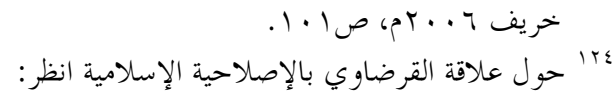

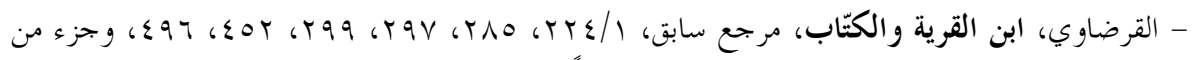

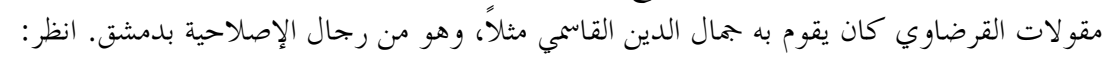

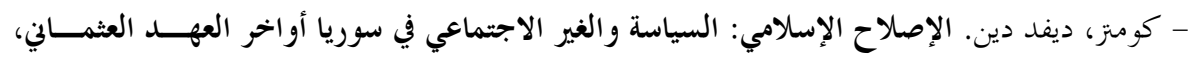

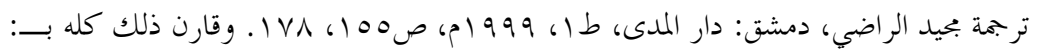

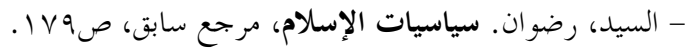




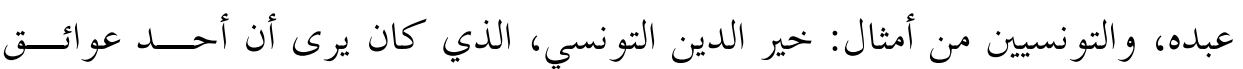

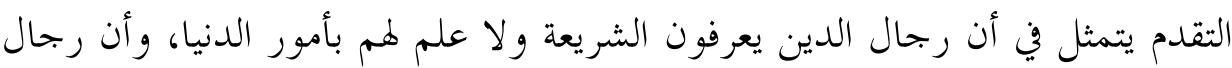

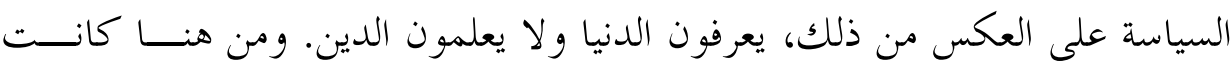

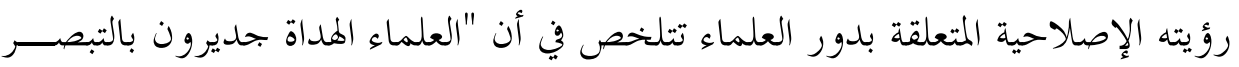

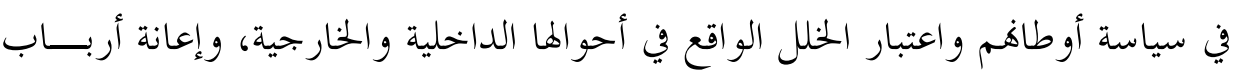
السياسة بترتيب تنظيمات منسوجة على منو ال الشريعة، معتبرين فيها مـــن المصــالح

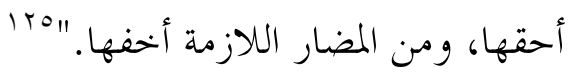

إن الدور الذي قام به القرضاوي يتصل هذذه الأفكار والتصورات نفسها، ومـــــ

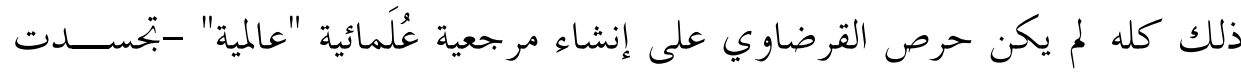

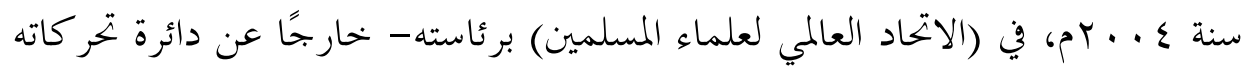

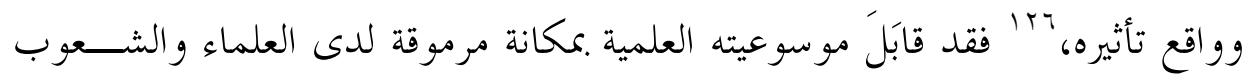

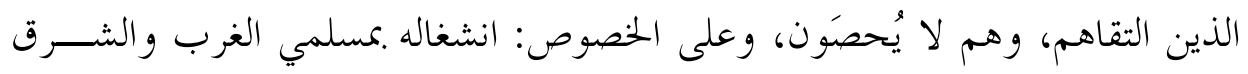

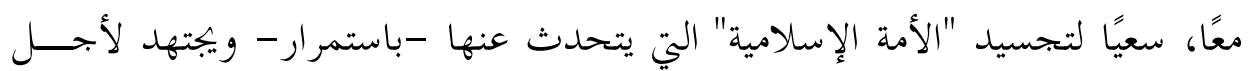

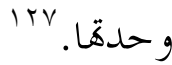

مror التونسي، خير الدين. أقوم المسالك في معرفة أحوال الممالك، تحقيق: المنصف الشنوفي، تونس: الدار التونسية

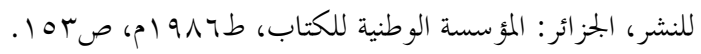

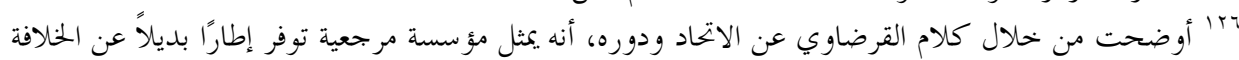

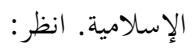

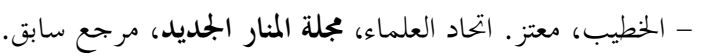

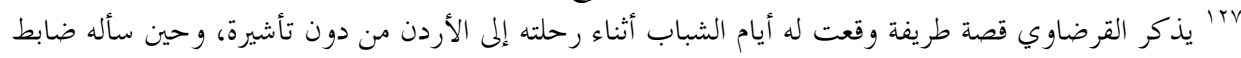

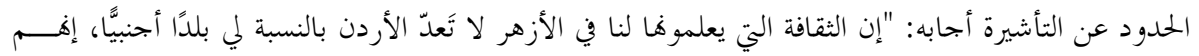

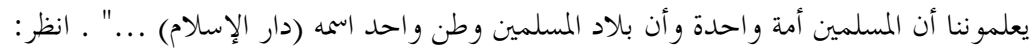

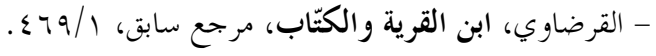


و بناء على ما سبق كله، لا يمكن لنا أن نعدّ القرضاوي "مثقفاً" بالمعنى الحــــديث

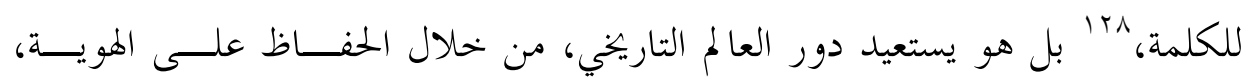

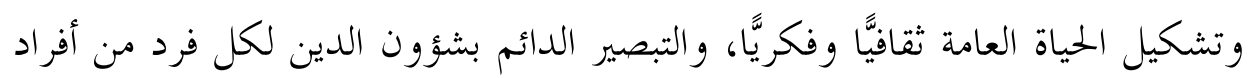

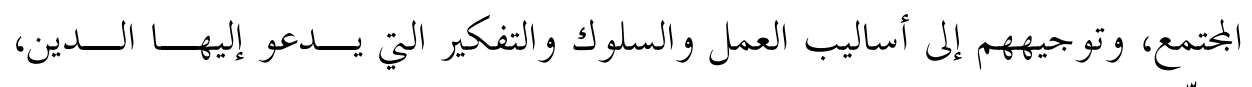

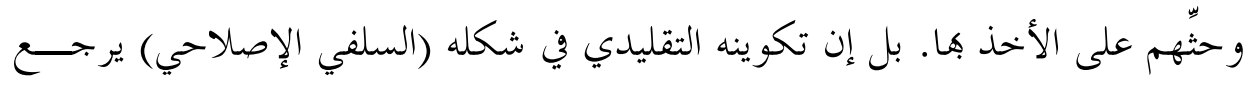
إليه الفضل الأكبر في دوره البارز الذي شغله.

أما فيما يخص شعبيته الكبيرة و الواسعة، فقد بُنيت على عو امل عديــــة، فقبــل

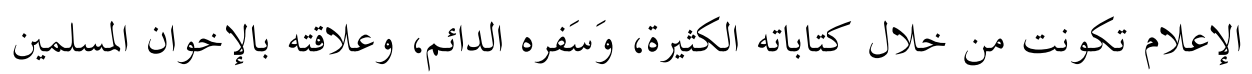

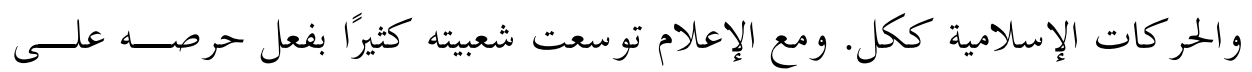
استخدام التقنيات الحميثة في نشر خطابه، وتدعيم مرجعيته، ومن هنا كان لفضــائية

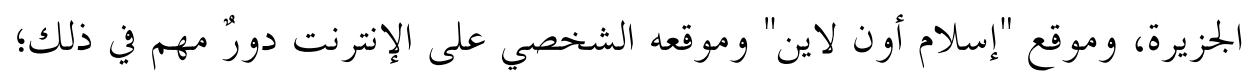

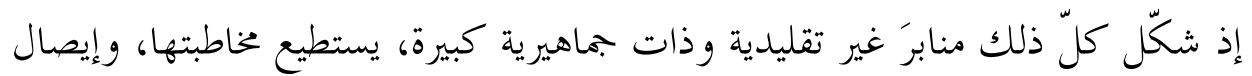

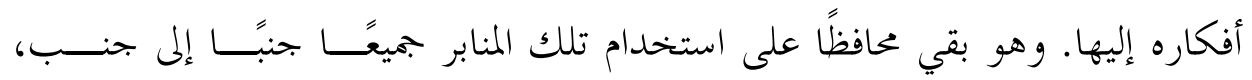

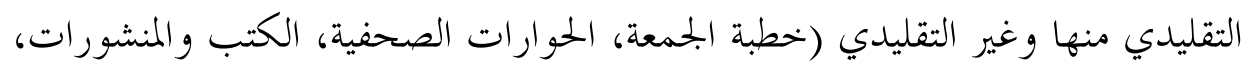

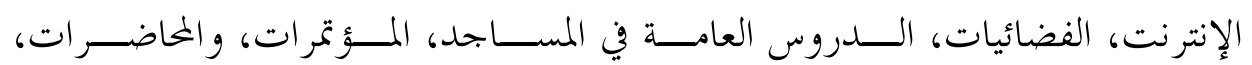
و المؤسسات الأهلية ...).

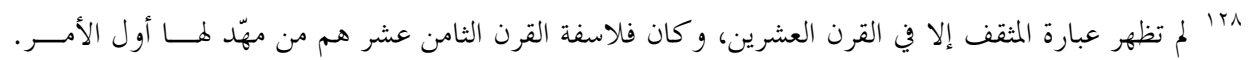

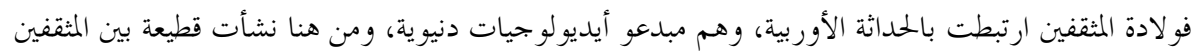

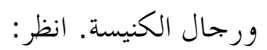

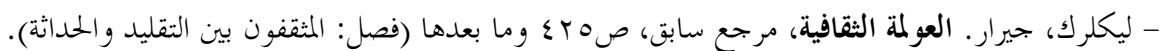

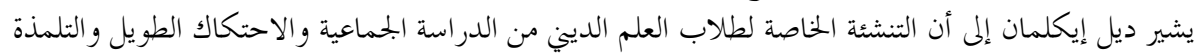

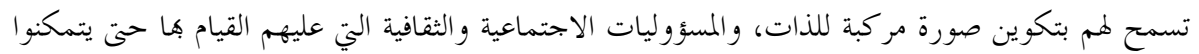

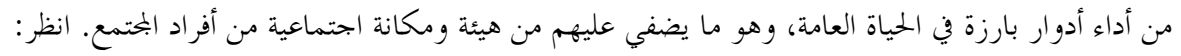

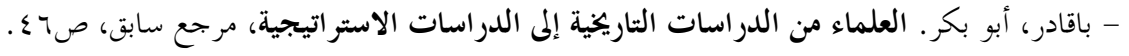


ومع ذلك فإن استخدامه للتقنيات الحلديثة واستثمارها في نشر خطابــهـ وفكــــه،

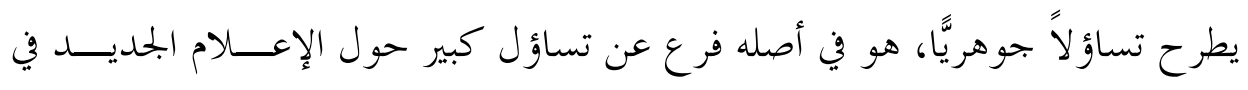

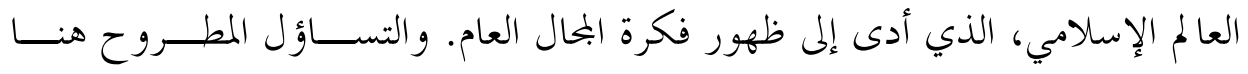
بخصوص القرضاوي، هو الكيفية التي أسهمت فيها وسائل الاتصال الحديثـــة (إعــلام وإنترنت وغيرها) بالإضافة إلى وسائل الاتصال القديمة (أشرطة الكاسيت، والصــــافة

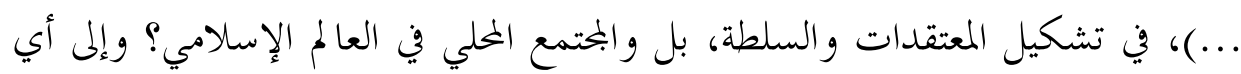

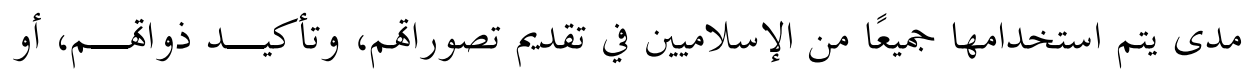

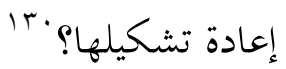

خاتمة:

هكذا أسفر نشاط الشيخ القرضاوي عن تحوّل فكرة المرجعية مـــن المنظومـــة إلى الشخص، .ما يمثله من "توجه" في ظل السياق التاريخي الذي شرحناه.

وأحسب أن وفاة القرضاوي الذي يبلغ الثمانين ســـة الآن، ســتطرح بعـض فض التحديات الصعبة، فلا أعتقد بوجود شخصية موازية له بكل مكوناته السابقة، مؤهلة

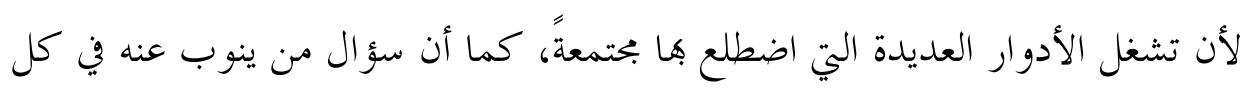

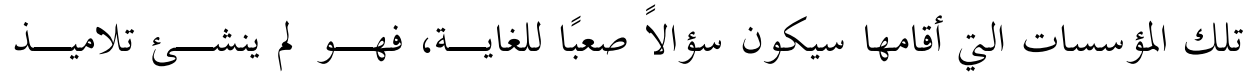

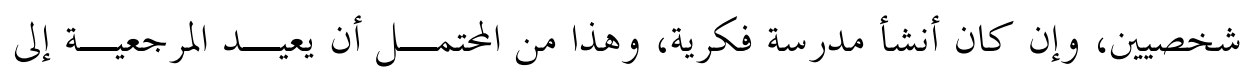
مرجعية الأفكار، و المنظومة الفكرية من جديد.

•"r عالج ديل إيكلمان وجون أندرسون بعض هذه الأفكار في كتاهما: "الإعلام الجديد في العالم الإسلامي"، انظر مر اجعة له في: ليجل

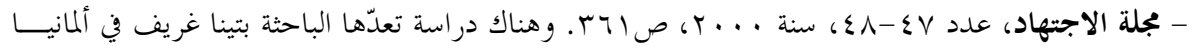

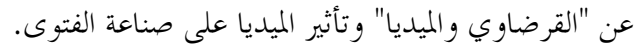


ويبقى أن ميراث الفكر الإصلاحي في شكله الذي انتهى إليه مع القرضاوي، ومن

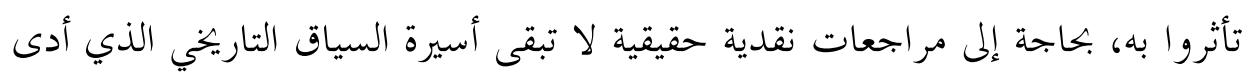

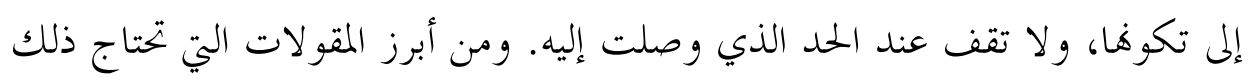
النقد والتجديد مقولات: الدولة الإسلامية، والوسطية الإسلامية، وفقه الأقليات. كما أن تطورات البحث المقاصدي ونقد متون السنّة، والدراسات الحديثة للقرآن الكريم، تتجاوز الأطروحات التي قدمها القرضاوي، لكن يبقى ذلك في الإطار المار المعرفي

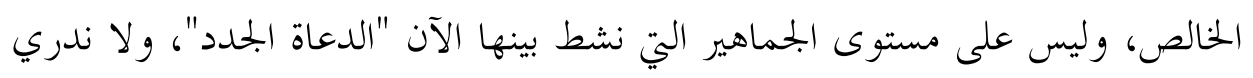
إلى أين سينتهون بالجماهير التي تتأثر همب. 